\title{
Degradation in Solid Oxide Cells During High Temperature Electrolysis
}

\author{
Manohar S. Sohal
}

May 2009

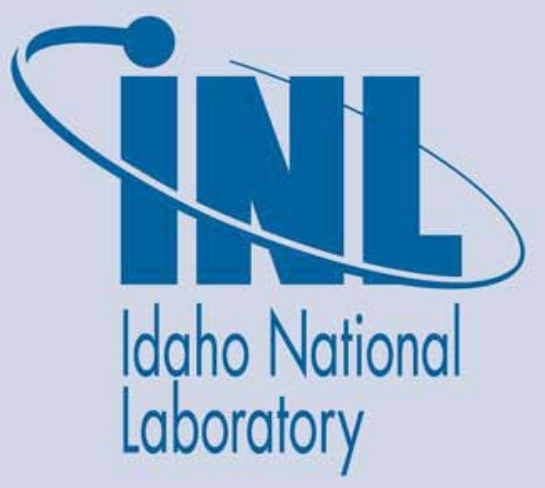

The INL is a U.S. Department of Energy National Laboratory operated by Battelle Energy Alliance 
INL/EXT-09-15617

\title{
Degradation in Solid Oxide Cells During High Temperature Electrolysis
}

\author{
Manohar S. Sohal
}

May 2009

\begin{abstract}
Idaho National Laboratory
Idaho Falls, Idaho 83415
\end{abstract}

http://www.inl.gov

\author{
Prepared for the \\ U.S. Department of Energy \\ Office of Nuclear Energy \\ Under DOE Idaho Operations Office \\ Contract DE-AC07-05ID14517
}




\section{DISCLAIMER}

This information was prepared as an account of work sponsored by an agency of the U.S. Government. Neither the U.S. Government nor any agency thereof, nor any of their employees, makes any warranty, expressed or implied, or assumes any legal liability or responsibility for the accuracy, completeness, or usefulness, of any information, apparatus, product, or process disclosed, or represents that its use would not infringe privately owned rights. References herein to any specific commercial product, process, or service by trade name, trade mark, manufacturer, or otherwise, does not necessarily constitute or imply its endorsement, recommendation, or favoring by the U.S. Government or any agency thereof. The views and opinions of authors expressed herein do not necessarily state or reflect those of the U.S. Government or any agency thereof. 



\begin{abstract}
The Idaho National Laboratory has an ongoing project to generate hydrogen from steam using solid oxide electrolysis cells (SOEC). The project goals are to address the technical and degradation issues associated with the solid-oxide electrolysis cells.. This report covers various degradation issues relating to solid oxide (electrolysis) cells, discussed during a workshop on "Degradation in Solid Oxide Electrolysis Cells and Strategies for its Mitigation," held in Phoenix, AZ on October 27, 2008. Major degradation issues relating to SOECs are:
\end{abstract}

- Delamination of $\mathrm{O}_{2}$-electrode and bond layer on steam $/ \mathrm{O}_{2}$-electrode side,

- Contaminants (Ni, Cr, Si, etc.) on reaction sites (triple phase boundary),

- Loss of electrical/ionic conductivity of electrolyte.

This list is not all inclusive. However this workshop summary can be useful in providing a direction for future research related to SOEC degradation. 


\section{ACKNOWLEDGEMENTS}

This report represents a compilation of the efforts of several researchers around the world who are involved in the development of solid oxide cells. Thus, it is an edited version of their research. The author acknowledges the contribution of his INL colleagues, the workshop participants (listed in Appendix A), and those researchers whose work has been cited in the references. Without their active participation, this report could not have been prepared. If any specific reference or a contribution has not been duly recognized, it is merely an oversight and is sincerely regretted. 


\section{CONTENTS}

ABSTRACT iii

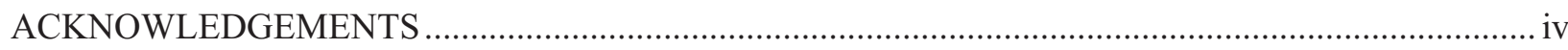

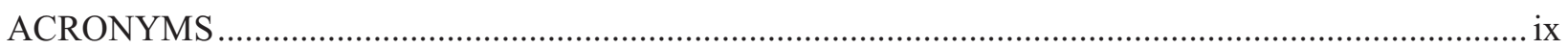

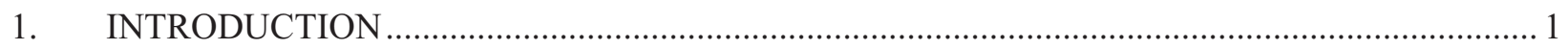

2. INL'S HIGH TEMPERATURE ELECTROLYSIS PROJECT …................................................ 3

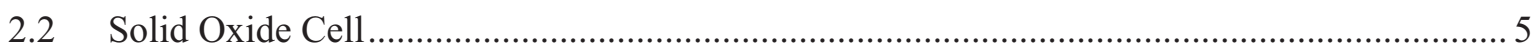

3. CATEGORIES OF LOSSES (DEGRADATION) IN A CELL ................................................... 8

3.1 Overview of Polarization Losses ................................................................................. 8

3.2 Activation (Charge Transfer) Polarization....................................................................... 9

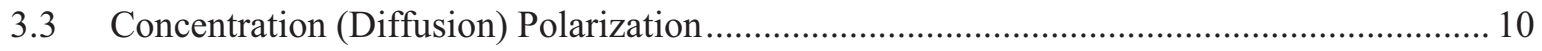

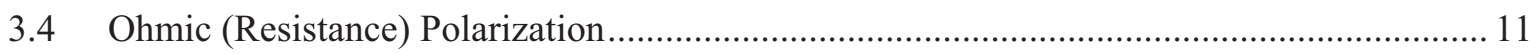

4. LITERATURE REVIEW OF DEGRADATION AND RELATED PHENOMENA IN

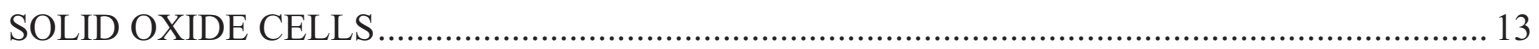

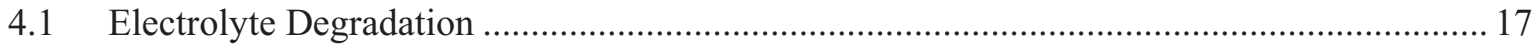

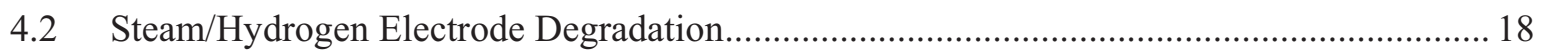

4.3 Oxygen Electrode and Interconnect Degradation ..................................................... 19

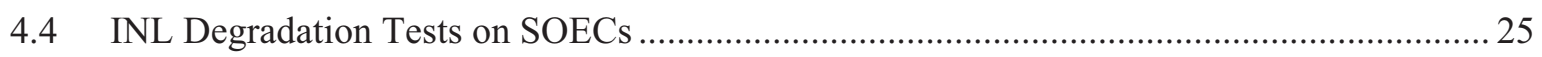

5. A WORKSHOP ON SOLID OXIDE CELL DEGRADATION …..............................................29

5.1 Understanding Solid Oxide Cell Operation as an Electrolyzer........................................... 29

5.2 Degradation Testing of SOECs by INL and Ceramatec ................................................. 29

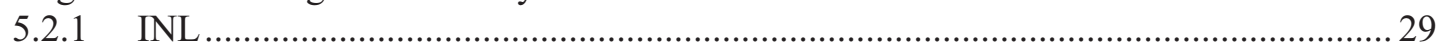

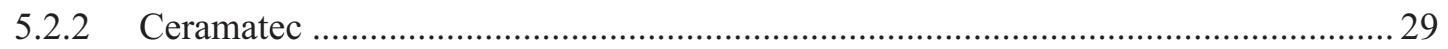

5.3 Post-Mortem of INL/Ceramatec SOEC by Argonne National Laboratory and the

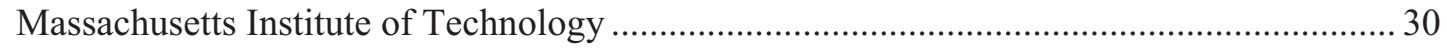

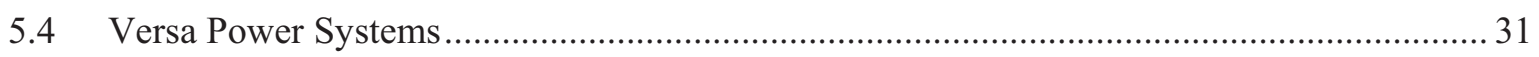

5.5 Forschungszentrum Jülich (FZJ) SOFC Degradation Studies .......................................... 32

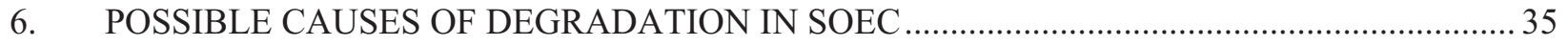

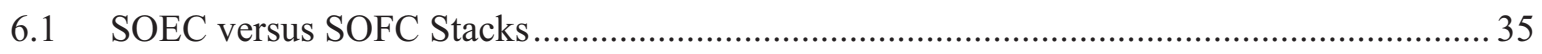

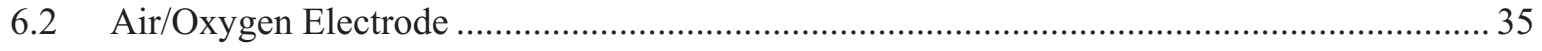

6.3 Air/ $\mathrm{O}_{2}$-Electrode Side Bond Layer …….................................................................... 35

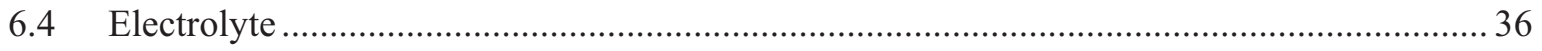

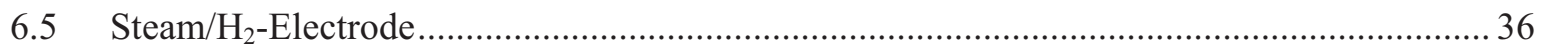

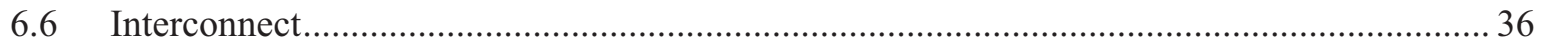

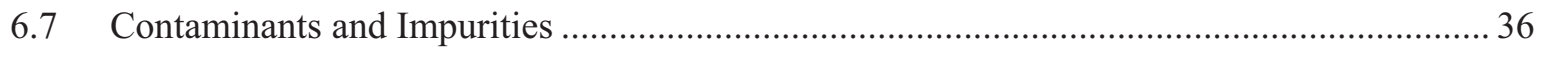

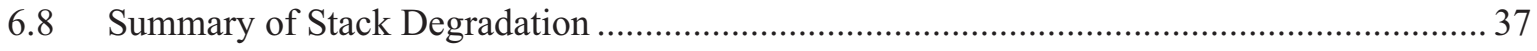




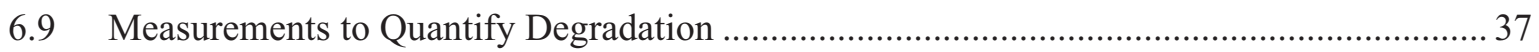

6.10 Measuring and Assessing Impact of Key Parameters .......................................................... 38

6.11 Electrochemical Impedance Spectroscopy ...................................................................... 38

7. SUMMARY AND RESEARCH NEEDS TO MITIGATE SOEC DEGRADATION ................... 40

7.1 Electrochemical Phenomena in SOEC Cells and Stacks …................................................ 40

7.2 Electrochemical Phenomena in SOEC Stacks and Cell Material Composition .................... 40

7.3 Modeling Electrochemical Phenomena and Stack Degradation ......................................... 40

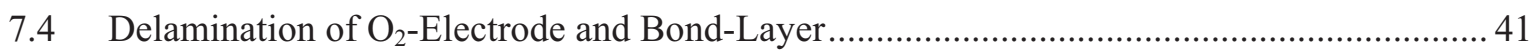

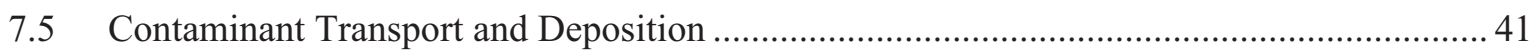

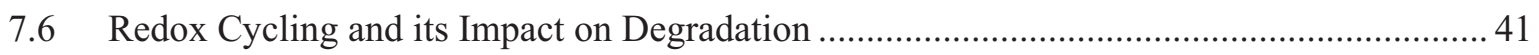

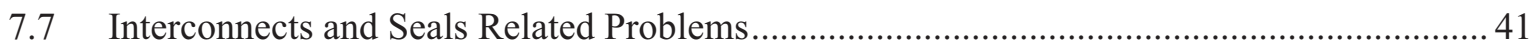

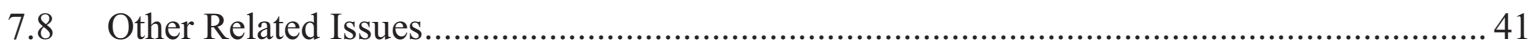

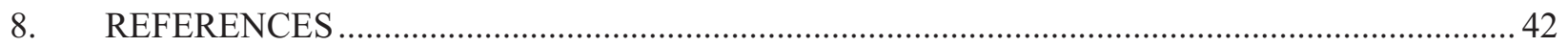

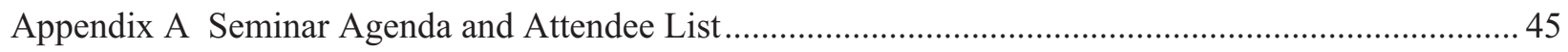

\section{FIGURES}

Figure 1. Schematic of HTE system coupled to an advanced nuclear reactor......................................... 1

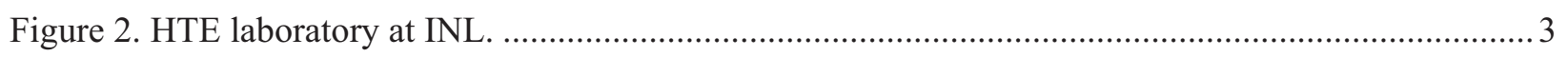

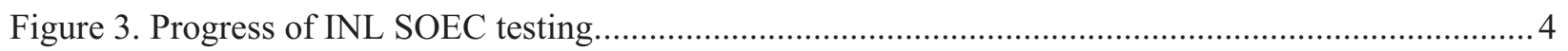

Figure 4. (a) SOEC; (b) solid oxide fuel cell (SOFC) operating in reverse compared to an SOEC

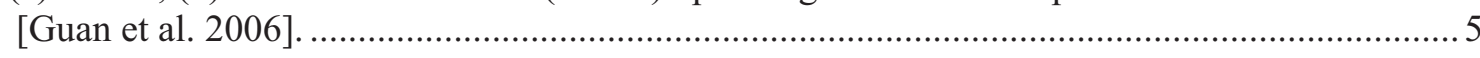

Figure 5. Ceramatec solid oxide cell/stack construction; right scanning electron microscopy

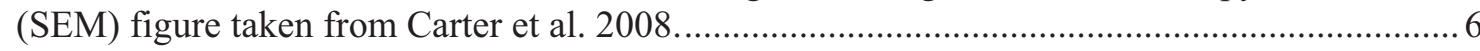

Figure 6. SOFC voltage-current characteristics for a single cell operating at $800^{\circ} \mathrm{C}$ [Windisch et al. 2002]

Figure 7. Operating mechanisms of solid oxide cells: (a) SOEC in electrolysis mode, and (b)

SOFC in fuel cell mode [Ni et al. 2006].

Figure 8. TPB in a solid oxide cell, shown as red dot, where reaction takes place [Hauch 2007a]........... 16

Figure 9. Individual cell performance in a three-cell stack operating at $800^{\circ} \mathrm{C}$ for $>1,000$ hours

[Guan et al. 2006].

Figure 10. Microstructure of a typical cell stack (from left to right - fuel electrode, electrolyte, barrier layer, and oxygen electrode); (a) a typical cross-section, (b) cross-section showing delamination between electrolyte and barrier layer, and (c) cross-section showing delamination between barrier layer and oxygen electrode [Guan et al. 2006].

Figure 11. Possible simple reaction mechanisms at the $\mathrm{H}_{2}$-electrode in a SOEC [Hauch 2007a]: (a) adsorption of $\mathrm{H}_{2} \mathrm{O}$ on the YSZ surface and proton diffusion on the surface or in the bulk of YSZ, (b) adsorption of $\mathrm{H}_{2} \mathrm{O}$ on the $\mathrm{YSZ}$ surface and electronic conduction in YSZ is assumed, (c) Adsorption of $\mathrm{H}_{2} \mathrm{O}$ on the Ni surface and diffusion of oxygen on 
the Ni surface, and (d) $\mathrm{H}_{2} \mathrm{O}$ adsorbed at the TPB and hydrogen diffusion on the Ni surface.

Figure 12. Area-specific resistance of a button cell as a function of time for the 1,100-hour test. ............26

Figure 13. Area-specific resistance of a 25 -cell stack as a function of time for a 1,000-hour test. ............26

Figure 14. Hydrogen production rates during 1,000-hour long-term test. ...............................................2 27

Figure 15. Time history of ILS module ASR values, voltages, and current over 700 hours of

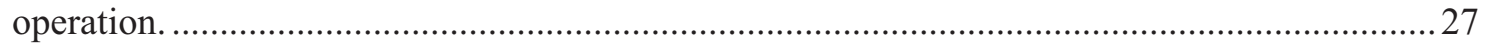

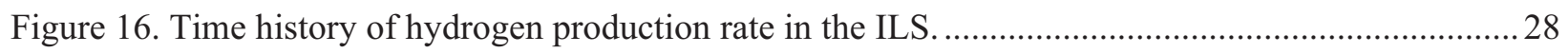

Figure 17. SEM view of the electrolyte and $\mathrm{O}_{2}$-electrode [Mawdsley et al. 2007] ................................28

Figure 18. A typical example of EIS measuring setup [Hauch 2007].

\section{TABLES}

Table 1. Commonly used materials in SOFC/SOEC [Gazzarri 2007] .................................................. 6

Table 2. Causes of degradation, failure mode, and needed measurements [Koehler et al. 2001]..............24

Table 3. Main degradation mechanisms in a SOFC [Blum et al. 2007]. ...................................................25 


\section{ACRONYMS}

3-D three dimensional

ASR area-specific resistance

CFD computational fluid dynamics

EIS electrochemical impedance spectroscopy

HTE high-temperature electrolysis

ILS Integral laboratory scale

INL Idaho National Laboratory

LSCF lanthanum strontium cobalt iron oxide

LSF strontium-doped lanthanum ferrite

LSM strontium-doped lanthanum manganite

LZO lanthanum zirconate

Ni-YSZ nickel-yttria stabilized zirconia

PNNL Pacific Northwest National Laboratory

ScSZ scandia-stablized zirconia

SDC samaria-doped ceria

SEM scanning electron microscopy

SOEC solid oxide electrolysis cells

SOFC solid oxide fuel cell

TEM transmission electron microscopy

TPB triple-phase boundary 


\section{Degradation in Solid Oxide Cells during High Temperature Electrolysis}

\section{INTRODUCTION}

Idaho National Laboratory (INL) is performing high-temperature electrolysis (HTE) research to generate hydrogen using solid oxide electrolysis cells (SOECs). A schematic depicting a high temperature gas-cooled reactor coupled to an HTE system is shown in Figure 1. This concept produces hydrogen using the heat and electricity generated by a high temperature nuclear reactor. The $\sim 900^{\circ} \mathrm{C}$ primary helium coolant uses about $85 \%$ of the thermal energy output of the reactor to drive a gas-turbine Brayton power cycle, which provides the electrical energy required for the HTE process. The remaining 15\% of the reactor thermal energy is used to generate steam at about $850^{\circ} \mathrm{C}$. The combination of a high-efficiency power cycle and the direct utilization of nuclear process heat yields a high overall thermal-to-hydrogen conversion efficiency of $50 \%$ or higher.

The objective of the INL project is to address the technical and scale-up issues associated with the implementation of SOEC technology for hydrogen production from steam. In the envisioned application, HTE would be coupled to an advanced nuclear reactor for efficient, large-scale non-fossil nongreenhouse-gas hydrogen production. The project supports a broad range of activities, including small bench-scale experiments, larger-scale technology demonstrations, detailed computational fluid dynamic

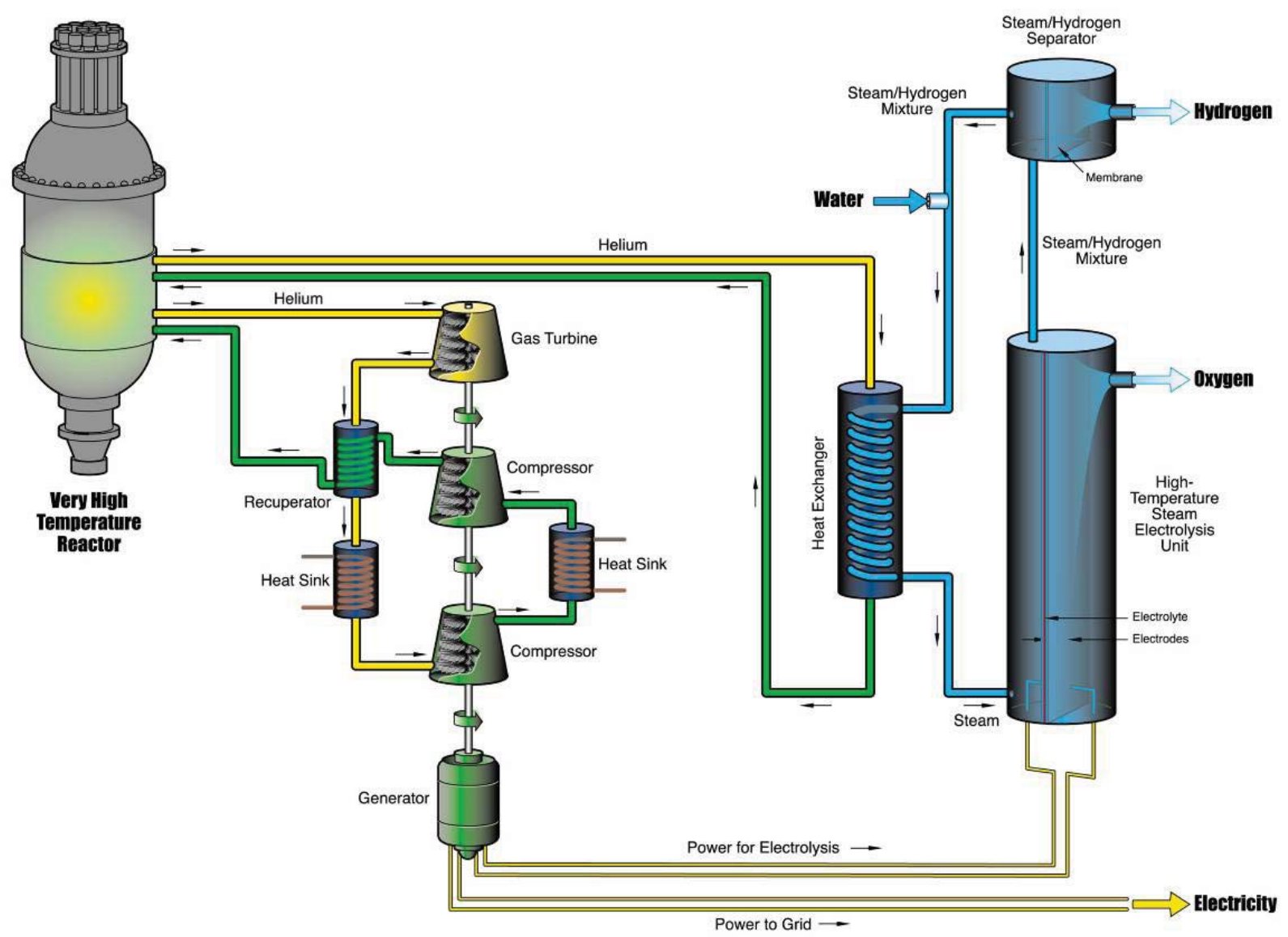

Figure 1. Schematic of HTE system coupled to an advanced nuclear reactor. 
modeling, and system modeling. A summary of the current status of these activities with a focus on the problem of cell and stack degradation is being provided in this report. For this technology to be successful in a large industrial setting, several technical, economical, and manufacturing issues have to be resolved. Some of the issues related to solid oxide cells include stack design optimization, identification and evaluation of cell performance degradation parameters and processes, integrity and reliability of the SOEC stacks, life-time prediction, and extension of the SOEC stacks. The widespread commercialization of SOECs is subject to the solution of problems related to their durability, reliability, and economics. 


\section{INL'S HIGH TEMPERATURE ELECTROLYSIS PROJECT 2.1 Status of High Temperature Electrolysis}

The research project underway at INL simultaneously addresses the technical and scale-up issues associated with the implementation of SOEC technology for efficient hydrogen production from steam. Researchers are coordinating a progression of electrolysis cell and stack testing activities at increasing scales while continuing their support of research activities in the areas of materials development, singlecell testing, detailed computational fluid dynamics (CFD) analysis, and system modeling. A photograph of the INL HTE laboratory is shown in Figure 2. This part of the laboratory is dedicated to small-scale experiments with single cells and small stacks.

A mixture of steam and hydrogen is fed to the electrolytic cells where the oxygen migrates through the solid-state electrolyte as $\mathrm{O}^{=}$ions because of the imposed voltage. The cell voltage is about $0.3 \mathrm{~V}$ lower than that required in conventional electrolyzers because of the high operating temperature. In addition, electrolytic reaction kinetics is much faster than in room-temperature electrolyzers, thus avoiding polarization losses. The mixture exiting the cells, about $25 \mathrm{vol} \%$ steam and $75 \mathrm{vol} \%$ hydrogen, enters a separator where the two components are separated either by condensation of the steam or diffusion of the hydrogen. A fraction of the produced hydrogen is recycled and mixed with additional steam to achieve the required inlet mixture composition. It is then reheated and returned to the solid oxide cells. The remaining steam can be removed from the hydrogen product stream through condensation. Like the hydrogen stream, the oxygen stream exiting the cells has a temperature of about $830^{\circ} \mathrm{C}$, which can be effectively used as needed.

Herring et al. [2007] presented the progress of INL HTE research from small-scale bench testing to large-scale demonstration. The INL has conducted experiments with following cells/stacks:

- $\quad$ Button cell testing $(\sim 1 \mathrm{~W})$

- Stack testing (200 W - $5 \mathrm{~kW}$ ) - electrode, electrolyte, and interconnect materials, flow field materials and fabrication, inter-cell electrical contact, cell and manifold sealing issues, and cell durability

- Integrated laboratory scale (ILS) testing (15 kW) - all previous issues plus multiple-stack thermal management, heat recuperation, feed-stock heating, and hydrogen recycling.

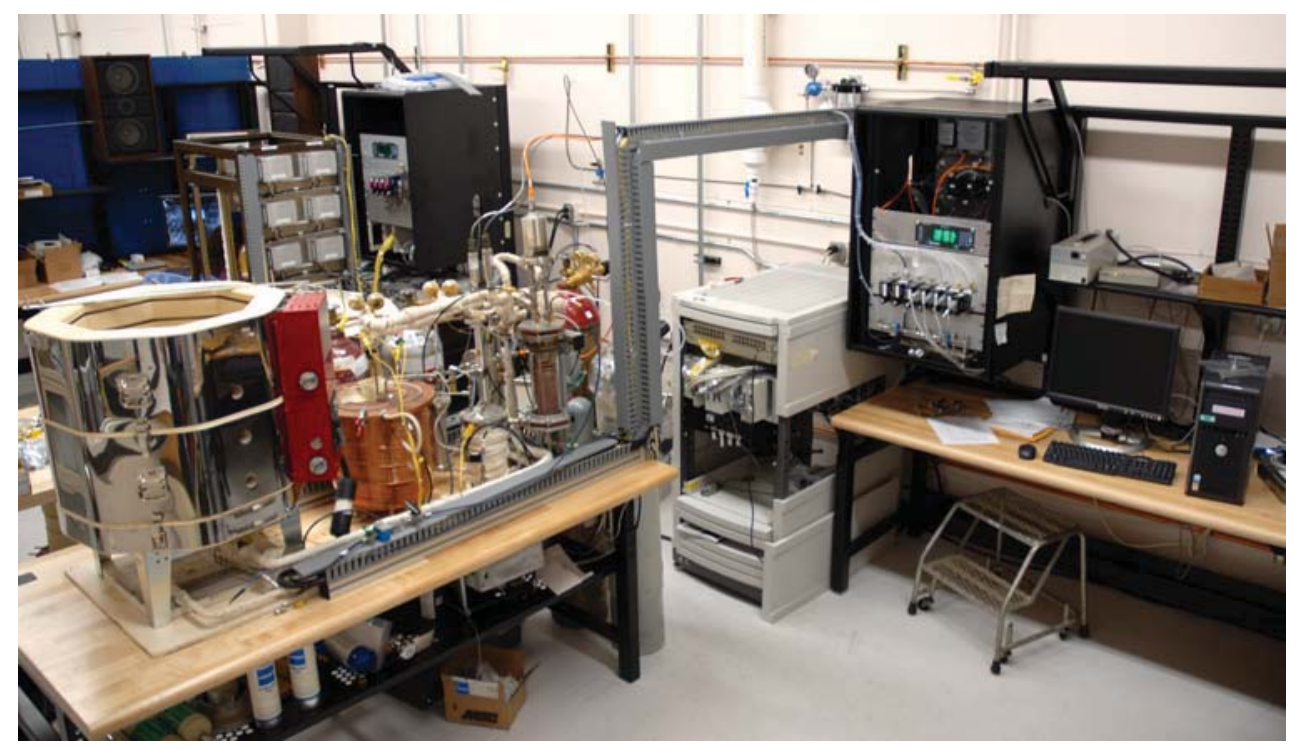

Figure 2. HTE laboratory at INL. 
Figure 3 shows the progression of the HTE experiments performed at INL during the last five years, from a $2.5 \mathrm{~cm}^{2}$ button cell to the ILS, which had an active area of $46,080 \mathrm{~cm}^{2}$ when all three modules were installed during 2008. This series of experiments represents a growth in active area (and in hydrogen production rate) by a factor of 15,000. The ILS design includes three four-stack modules with 60 electrolysis cells in each stack for a total of 12 stacks and 720 cells in a single hot zone. This configuration utilizes solid oxide cells similar to those used in the small stacks previously tested at INL. In the ILS, the inlet steam-hydrogen flow was preheated to $830^{\circ} \mathrm{C}$ (electrolyzer operating temperature) prior to entering the hot zone using superheaters and recuperators. The electrolysis module is configured so that the steam/hydrogen gas mixture enters through the bottom of the steam inlet manifold and exits through the bottom of the outlet manifold in the module's center. Airflow enters through the bottom of the air inlet manifold, flows through the stack perpendicular to the steam-hydrogen gas mixture, and exits at the front of the stacks directly into the hot zone. Furthermore, each electrolysis module has its own independent instrumentation system; which allowed for independent testing of each of the three HTE ILS modules under different operating conditions (gas mixture, current density, etc.). To measure fuel cell performance, the area-specific resistance (ASR) value was closely monitored. Testing of fuel cells shows that the resistance of the cell gradually increases over time, reducing the hydrogen production rate. This degradation was evidenced by increased calculated ASR values. As the solid oxide cell technology improves, the cell's lifetime and degradation should also improve, resulting in efficiently producing large quantities or hydrogen over long periods of time ( $\geq 20,000 \mathrm{hrs})$.

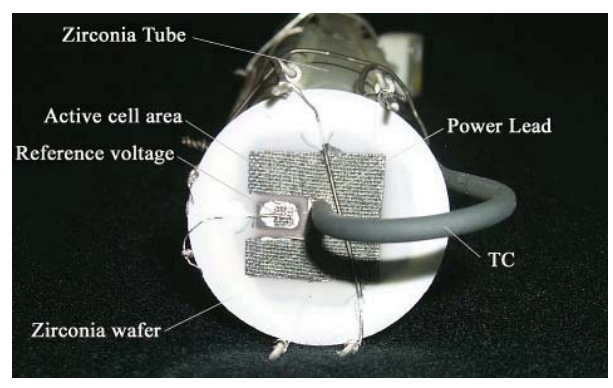

Button cell, $3.2 \mathrm{~cm}^{2}$ (2003)

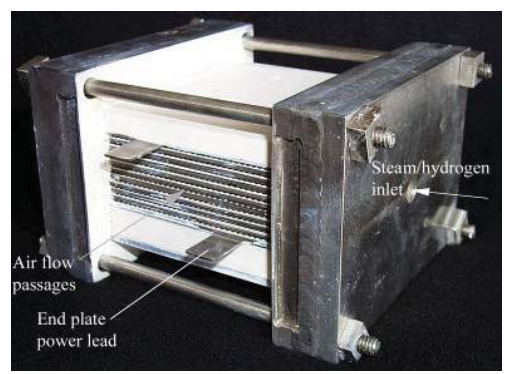

10-cell stack, $640 \mathrm{~cm}^{2}(2004)$

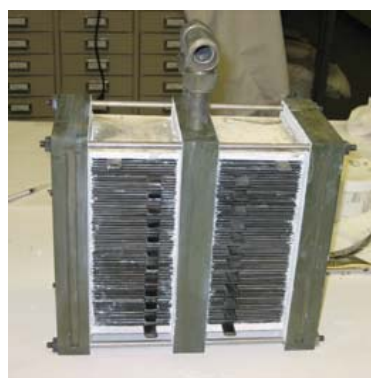

120-cell half-module, $7,680 \mathrm{~cm}^{2}$ (2006)

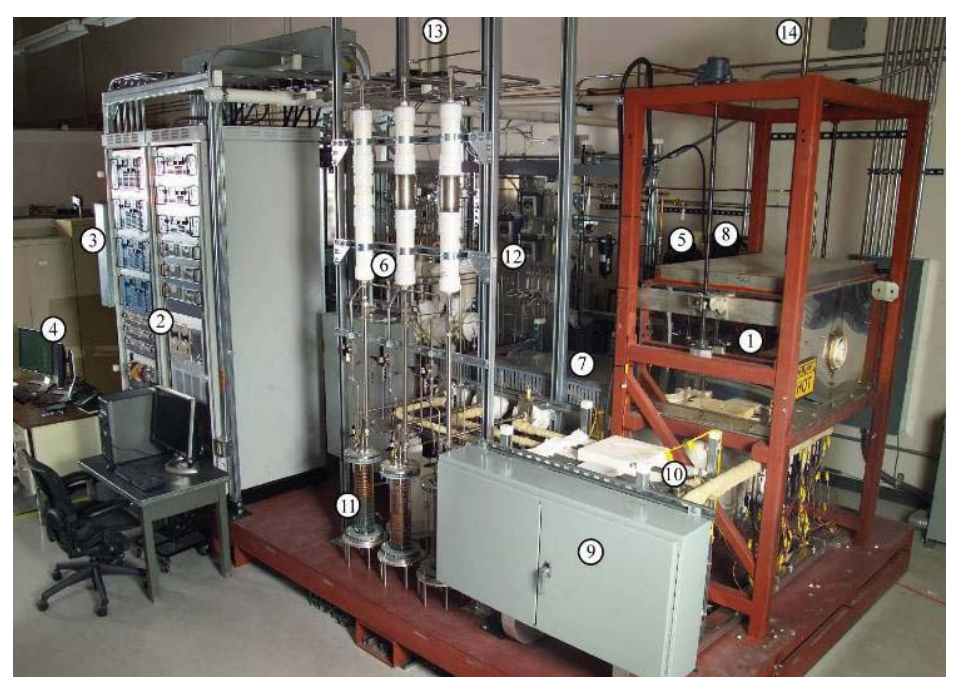

Integrated Laboratory Scale 720 cells, 3 modules, 46,080 $\mathrm{cm}^{2},(2008)$

\begin{tabular}{|c|l|}
\hline ID & \multicolumn{1}{|c|}{ Component } \\
\hline 1 & Hot zone enclosure lid \\
\hline 2 & Power supply and instrument racks \\
\hline 3 & Electrical distribution cabinet \\
\hline & $\begin{array}{l}\text { Data acquisition and control } \\
\text { monitors }\end{array}$ \\
\hline 5 & Deionized water system \\
\hline 6 & Steam generator \\
\hline 7 & Steam and $\mathrm{H}_{2}$ superheaters \\
\hline 8 & Air compressor \\
\hline 9 & Patch panel \\
\hline 10 & Product finned cooler \\
\hline 11 & Steam condenser \\
\hline 12 & Mass flow controllers \\
\hline 13 & $\mathrm{H}_{2}$ vent \\
\hline 14 & Air and $\mathrm{O}_{2}$ vent \\
\hline
\end{tabular}

Figure 3. Progress of INL SOEC testing. 


\subsection{Solid Oxide Cell}

A solid oxide cell is a key component of the electrolysis system. It consists of three main components: an electrolyte and two electrodes (Figures 4 and 5). The electrolyte is a gas-tight ceramic membrane that can conduct ions and is sandwiched between two porous electrodes that can conduct electrons: the steam/hydrogen electrode (or anode in fuel cell mode) and the air/oxygen electrode (or cathode in the fuel cell mode). In the fuel cell mode, oxygen molecules dissociate at the oxygen electrode and combine with electrons coming from external electric power source to form oxygen ions. The oxygen ions conduct through the electrolyte and migrate towards the hydrogen electrode. The fuel (hydrogen or natural gas) is fed to the anode and reacts with the oxygen ions to form water and $\mathrm{CO}_{2}$. If the fuel cell is operated in the electrolysis mode, the names and function of the electrodes are reversed as shown in Figure 4a.

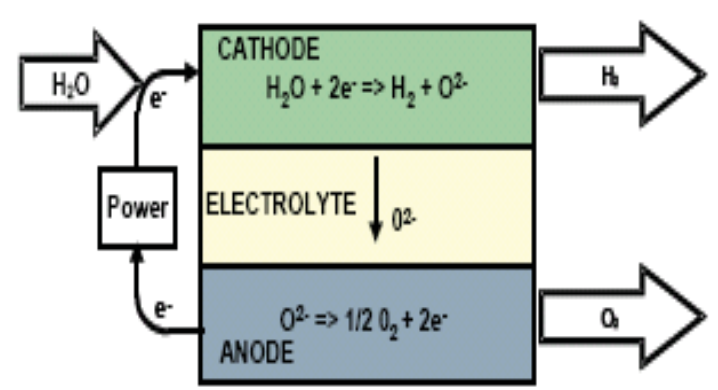

(a)

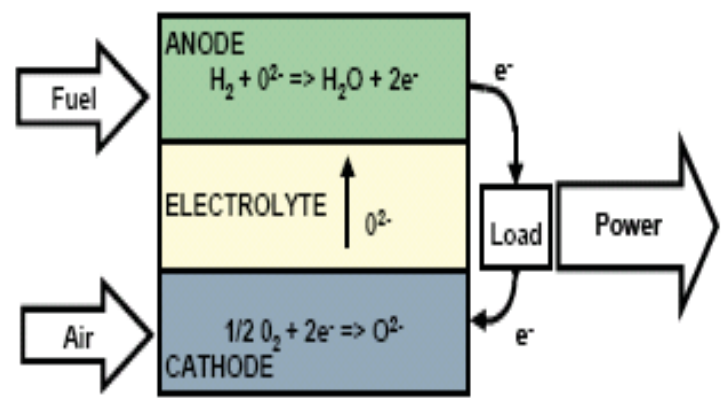

(b)

Figure 4. (a) SOEC; (b) solid oxide fuel cell (SOFC) operating in reverse compared to an SOEC [Guan et al. 2006]. 

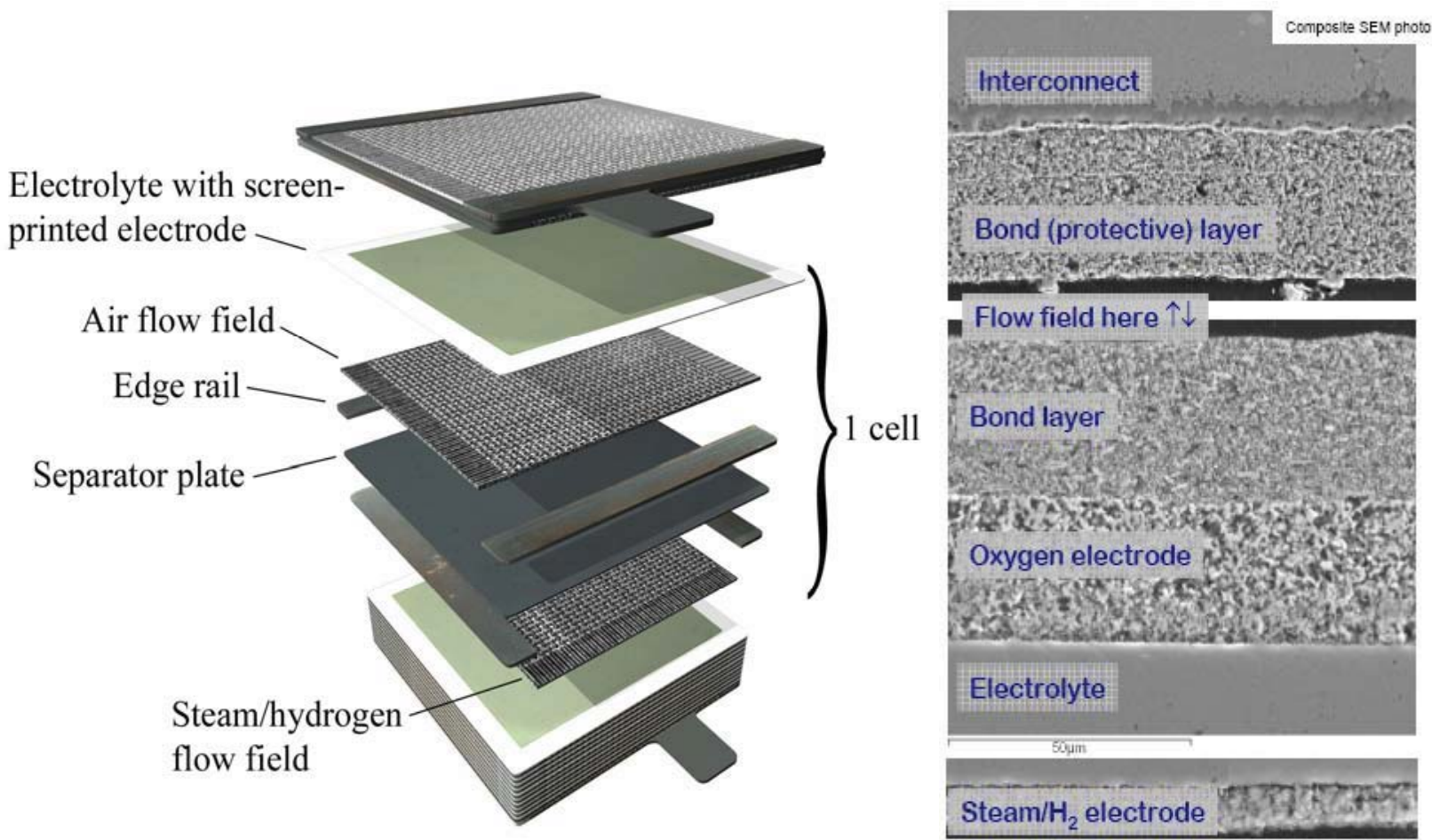

Figure 5. Ceramatec solid oxide cell/stack construction; (scanning electron microscopy figure on the right is taken from Carter et al. 2008).

The most common materials currently used for the solid oxide cells are listed in Table 1 [Gazzarri 2007]. The electrolyte is a dense gas-tight ceramic layer, usually made from yttria stabilized zirconia (YSZ) with yttria content of $8 \mathrm{~mol} \%$ to fully stabilize the electrolyte composition. The performance of the electrolyte depends on how well it can conduct oxide ions $\left(\mathrm{O}^{-}\right)$. The thinner the electrolyte, the higher its ion conductivity and the lower the cell's ohmic resistance. In an electrolyte supported cell, the electrolyte thickness is large (150-250 $\mu \mathrm{m})$, which leads to relatively high ionic resistance. Therefore, if the mechanical strength can be provided by the steam $/ \mathrm{H}_{2}$ electrode, the electrolyte thickness can be reduced by a factor of $\sim 10$.

Table 1. Commonly used materials in SOFC/SOEC [Gazzarri 2007].

\begin{tabular}{|l|l|l|}
\hline \multicolumn{1}{|c|}{ Component } & \multicolumn{1}{|c|}{ Material } & \multicolumn{1}{c|}{ Acronym } \\
\hline Steam/hydrogen electrode & $\mathrm{Ni}_{-}-\mathrm{Y}_{\mathrm{x}} \mathrm{Zr}_{1-\mathrm{x}} \mathrm{O}_{2-\mathrm{x} / 2}$ (nickel-yttria stabilized zirconia) & Ni-YSZ \\
\hline Electrolyte & $\mathrm{Y}_{\mathrm{x}} \mathrm{Zr}_{1-\mathrm{x}} \mathrm{O}_{2-\mathrm{x} / 2}(\mathrm{yttria}$ stabilized zirconia) & $\mathrm{YSZ}$ \\
\hline Air/oxygen electrode & $\mathrm{Sr}_{\mathrm{x}} \mathrm{La}_{1-\mathrm{x}} \mathrm{MnO}_{3-\delta}+\mathrm{Y}_{\mathrm{x}} \mathrm{Zr}_{1-\mathrm{x}} \mathrm{O}_{2-\mathrm{x} / 2}$ (doped lanthanum manganite) & $\mathrm{LSM}$-YSZ \\
\hline Interconnect & Chromium based alloys/ceramics or stainless steel & $\mathrm{SS}$ \\
\hline
\end{tabular}

The most common anode material for SOFC is a porous cermet (ceramic-metal) made from $\mathrm{Ni}$ and YSZ. Electronically-conductive, gas-tight interconnect plates connect the individual cells to form a stack. The ionic conductivity of ceramics is highly dependent on the ceramic temperature. Thus, high operating temperatures are required to obtain sufficient overall conductivity in the solid oxide cell. YSZ exhibits acceptable conductivity in the $700-1,100^{\circ} \mathrm{C}$ temperature range, but if thermal cycling occurs, such as at start-up, the high operating temperature results in large thermal stresses in the cell components. Stresses can also be caused by large thermal gradients generated by the uneven distribution of electrochemical reaction sites. Finally, fabrication of the cell components also requires high temperatures that can cause 
detrimental residual stresses within the cell components. Guan et al. [2006] performed studies for reversible solid oxide cells, which were tested in both fuel cell and electrolysis modes. They selected YSZ ( $8 \mathrm{~mol} \% \mathrm{Y}_{2} \mathrm{O}_{3}$ doped zirconia) as electrolyte material. Selected oxygen electrodes were strontium-doped lanthanum manganite (LSM), strontium-doped lanthanum ferrite (LSF), and lanthanum strontium cobalt iron oxide (LSCF). They used samaria-doped ceria (SDC) interlayer for LSF and LSCF. LSCFs have increased ionic conductivity and may reduce degradation rate in electrolysis mode. For hydrogen electrode, Ni-YSZ was selected with varying volume fraction of Ni (40-80\%).

In the fuel cell mode, the oxygen electrode is fed with air while the hydrogen electrode is fed with hydrogen or natural gas. Thus, the properties of the oxygen electrode should be such that it provides a component for oxygen gas to be easily reduced and similarly, the function of the hydrogen electrode is to oxidize the fuel gas. At the oxygen electrode, where electrons are supplied via the external electrical power, oxygen molecules are reduced to oxygen ions. The oxygen ions are conducted through the electrolyte to the hydrogen electrode. At the hydrogen electrode, oxygen ions oxidize the fuel gas which forms water and carbon dioxide, while the resulting free electrons are transported via the external circuit back to the oxygen electrode. The solid oxide electrolyte separates the reduction and oxidation reactions. Thus, in the electrolysis mode, the electrical energy is used to split hydrogen from steam. The electrolysis process is the reverse of the fuel cell process. 


\section{CATEGORIES OF LOSSES (DEGRADATION) IN A CELL}

\subsection{Overview of Polarization Losses}

The polarization losses/degradation definitions described in this chapter are strictly written for a SOFC. Appropriate care should be applied when applying the same fundamentals for a SOEC case.

When a fuel cell is not connected to an external load, there is no current flow and the maximum reversible cell voltage or open circuit voltage can be calculated by the equilibrium Nernst potential for the specific electrochemical reaction system. The Nernst potential, $\mathrm{V}_{\text {Nerst }}$, is calculated using the partial pressure of the chemical species at the cell inlet or outlet. However, it is more appropriate to calculate an average of the inlet and outlet values, $V^{\mathrm{i}}{ }_{\text {Nernst }}$ and $\mathrm{V}^{\mathrm{o}}{ }_{\text {Nernst, }}$, where superscripts $\mathrm{i}$ and o represent inlet and outlet locations.

$$
\begin{aligned}
& \mathrm{V}_{\text {Nernst }}=1 / 2\left(\mathrm{~V}_{\text {Nernst }}^{\mathrm{i}}+\mathrm{V}_{\text {Nernst }}^{\mathrm{o}}\right) \\
& V_{\text {Nernst }}^{i}=-\frac{\Delta G^{0}}{n_{e} F}-\frac{R T}{n_{e} F} \ln \left(\frac{p_{\mathrm{H}_{2} \mathrm{O}}^{i}}{p_{\mathrm{H}_{2}}^{i} \sqrt{p_{\mathrm{O}_{2}}^{i}}}\right) \\
& V_{\text {Nernst }}^{o}=-\frac{\Delta G^{0}}{n_{e} F}-\frac{R T}{n_{e} F} \ln \left(\frac{p_{\mathrm{H}_{2} \mathrm{O}}^{o}}{p_{\mathrm{H}_{2}}^{o} \sqrt{p_{\mathrm{O}_{2}}^{o}}}\right)
\end{aligned}
$$

where $\Delta G^{0}$ is change in Gibbs free energy at standard conditions and equals $-R T \ln [K(T)]$, $R$ is universal gas constant, $\mathrm{T}$ is cell temperature, $\mathrm{K}$ is equilibrium constant, $\mathrm{n}_{\mathrm{e}}$ is number of electrons participating in the electrochemical reaction, $\mathrm{F}$ is Faraday's constant, and $\mathrm{p}$ is the partial pressure of respective species.

When a fuel cell starts supplying electric current to an external load, its operating voltage drops because of irreversibilities associated with internal resistances. The difference between the maximum reversible cell voltage or open circuit voltage $\left(\mathrm{V}_{\text {open }}\right)$ and the operating cell voltage $\left(\mathrm{V}_{\mathrm{OCV}}\right)$ is termed polarization loss $(\eta)$. Cell performance depends on the overall cell reaction and the type of reactants at the electrodes and the reaction product(s). A detailed description of polarization losses is given by IversTiffée and Virkar [2003] and Akkaya [2007]. The total polarization loss of an operating cell consists of three dominant parts: activation (or charge transfer) polarization $\left(\eta_{\text {act }}\right)$, concentration (or diffusion) polarization which includes chemical reaction polarization $\left(\eta_{\text {conc }}\right)$, and ohmic resistance polarization $\left(\eta_{\mathrm{ohm}}\right)$.

$\eta=\eta_{\text {act }}+\eta_{\text {conc }}+\eta_{\text {ohm }}$

The current efficiency can be stated as the percent of current passing through an electrolytic cell (or electrode) that accomplishes the desired chemical reaction compared to the ideal case. For example, in the hydrogen fuel cell, ideally every hydrogen $\left(\mathrm{H}_{2}\right)$ molecule would react to produce two electrons that would contribute to the current flow. The inefficiencies arise from reactions other than the intended one taking place at the electrodes, or the side reactions consuming the current. Some hydrogen for instance, may go through the electrolyte and not react at all, or the hydrogen does react but the resulting current is driven through the electrolyte (not the electrode) and never contributes to the current flow.

The voltage efficiency is defined as the net voltage (cell equilibrium voltage minus the irreversible losses) divided by the maximum voltage. The irreversible voltage losses are attributed to polarization losses that primarily originate from three sources: activation, concentration, and ohmic polarizations. 
Thus, the net cell voltage is the open circuit voltage, minus the various polarization losses, and can be written as:

$\mathrm{V}_{\text {cell }}=\mathrm{V}_{\text {open }}-\left(\mathrm{V}_{\text {act }}+\mathrm{V}_{\text {conc }}+\mathrm{V}_{\text {ohm }}\right)=\mathrm{V}_{\text {Nernst }}-\mathrm{V}_{\text {loss }}$

Figure 6, developed by Windisch et al. [2002], shows the relative magnitude of various polarization losses in a SOFC. It shows that activation losses are the dominant mode of three types of polarization losses. It also shows the upper limit of current density for the fuel cell to operate.

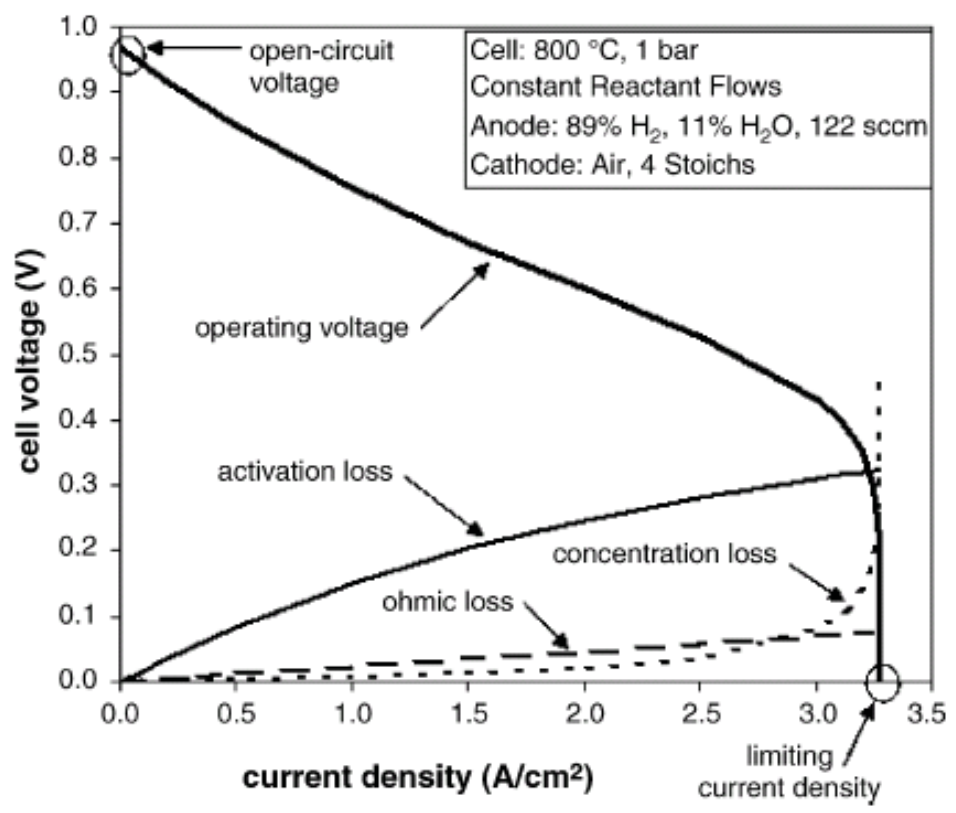

Figure 6. SOFC voltage-current characteristics for a single cell operating at $800^{\circ} \mathrm{C}$ [Windisch et al. 2002].

The overpotentials can be determined by the several models available in the literature, for example, Virkar [2007]. However, the concentration overpotentials are different between the SOEC and SOFC modes because of the different gas transport mechanisms in the porous electrodes. Ni et al. [2006] showed that concentration overpotentials are the sole factor responsible for the different current-voltage (i-V) characteristics between the SOEC and SOFC modes. Their analytical model shows the difference between the SOEC and SOFC because of differences in the gas transport mechanisms of the two different modes. The selection of an electrode support can greatly affect the overall performance of a reversible solid oxide cell. A hydrogen-electrode (fuel cell anode) support is favorable to the SOFC mode while an oxygenelectrode (electrolysis anode) support is favorable to the SOEC mode. Therefore, the details of both SOEC and SOFC operating conditions should be carefully considered in their design. If a specified solid oxide cell is mainly used for hydrogen generation, an oxygen-electrode (electrolysis anode) supported cell is recommended.

\subsection{Activation (Charge Transfer) Polarization}

Electrochemical reactions at the electrodes involve charge transfer, by which a neutral species is converted into an ion or an ion is converted into a neutral species. The electrodes may conduct either electrons or ions or both. Losses incurred during ionic and electronic transfer are sometimes called activation losses. The electrode reaction rate is a function of operating conditions and electrode materials. The reactions can result in adsorption, electron transfer or desorption. The activation energy can be reduced by the presence of a catalyst. The activation polarization is nonlinear, dominant at low current 
density, and related to a physical or electrical barrier at the electrolyte-electrode interfaces. At the anode and the cathode (in a fuel cell mode), the reactants diffuse to the reaction sites where the activation polarization must be overcome before the reduction and oxidation reactions take place. The activation potential is generally the largest of the three polarizations at low and medium temperatures. Catalysts are often used to overcome the activation potential and enable the reaction to proceed faster. At higher temperatures $\left(>800^{\circ} \mathrm{C}\right)$ in fuel cells, the activation potential is lower and the cells generally do not need a catalyst. The charge double layer is caused by the accumulation of ions and electrons on or near an electrode-electrolyte interface. This layer stores energy like a capacitor. This is often considered to be one reason for the occurrence of the activation polarization.

The activation polarization is estimated by the Tafel equation, which shows a straight line relationship between overpotential and the log of current density. The current density or exchange current density is the flow of electrons to and from the electrolyte. Semi-empirical correlations are used to calculate polarization. However, their accuracy is questionable over a wide range of operating conditions. The Butler-Volmer (B-V) equation is therefore used to calculate current density.

$i=i_{0}\left[\exp \left(\frac{\beta n_{e} F V_{a c t}}{R T}\right)-\exp \left(\frac{(1-\beta) n_{e} F V_{a c t}}{R T}\right)\right]$

where $i$ is current density, $i_{o}$ is the exchange current density, and $\beta$ is transfer coefficient. The exchange current density, $i_{o}$ is the forward and reverse electrode reaction rate at equilibrium potential. The transfer coefficient, $\beta$, is defined as the fraction of activation polarization that affects the activation energy barrier and thus the rate of electrochemical transformation. It is assumed to be $\sim 0.5$ for fuel cell mode, but values in the range $0.3-0.6$ have been used to match the experimental data. The exchange current density depends on cell materials, construction, and operating temperature, but in many studies it is taken to be a constant. Noren and Hoffman [2005] have given two approximations to solve the B-V equation. When the activation loss is large ( $>200 \mathrm{mV})$, the first term in the B-V Equation (6) is much larger than the second one, which can then be neglected. The simplified equation is the high-field approximation called Tafel equation, and is valid for $\mathrm{i} / \mathrm{i}_{0}>4$. For $\mathrm{i} / \mathrm{i}_{\mathrm{o}}<1$, higher order nonlinear terms are neglected and a low-field approximation, also called linear current-potential equation, is achieved. Considering the shape of the $\mathrm{B}-\mathrm{V}$ equation (hyperbolic sine function) and considering the reduction charge transfer coefficient to be equal to the oxidation charge transfer coefficient (for both cathode and anode), the activation loss can be calculated as

$V_{a c t} \cong \frac{R T}{\alpha_{1} F} \sinh ^{-1}\left(\frac{i}{2 i_{0}}\right)$

Noren and Hoffman [2005] have shown that the B-V equation and hyperbolic sine approximation are nearly identical and match well with experimental data obtained by Pacific Northwest National Laboratory (PNNL). It is critical for this current density to be as high as possible because it is easier to keep a process going than to start it from scratch. Many methods are known and others are being investigated that can reduce activation polarization, such as raising cell temperature, doping the electrode with effective catalysts, increasing the surface area of the electrode by making it rougher, increasing reactant concentration, and increasing the pressure.

\subsection{Concentration (Diffusion) Polarization}

When the electrode reactions are not supplied with sufficient reactants or the reaction products do not move away fast enough, the loss in cell performance is called concentration polarization. A reduced supply of reactants will slow down the reaction. Chemical reaction polarization has the same effect as 
concentration polarization, but is due to limiting reactions for producing or removing reactants or products. The diffusion loss and the chemical reaction loss are sometimes collectively called mass transport polarization..

The concentration polarization dominates at high current density. It is related to diffusion of reactants and products, and is often referred to as a mass transport loss because the reduction of reactant concentration is the result of a failure to transport sufficient reactant to the electrode surface. For higher current density, the flow rate of reactants required for the electrochemical reactions should also increase. Eventually, the rate of ionic transport through the cell cannot keep up with the rate at which the reactants are consumed. The concentration of reactants at the reaction sites begins to drop and thus, the voltage drops. At the oxygen electrode, as oxygen is being used (typically from an air supply), a reduction in the concentration of oxygen in the region of the electrode occurs. This change in concentration causes a drop in the partial pressure of the oxygen; the magnitude of the drop depends on the current flow in the fuel cell. Other factors of the pressure drop are the physical characteristics of the fuel cell, such as how well the air supply circulates to replenish the oxygen. Similarly, a drop in gas pressure occurs at the steam/hydrogen electrode as hydrogen is used and current is generated. As with the cathode, the rate of this drop will depend on the characteristics of the fuel cell, such as the gas supply system. The gas supply system will consist of cell flow channels and fluid resistance, which will impact flow distribution.

The following equation for concentration loss can be developed by considering that at an electrode, fuel gas pressure change results in voltage drop:

$\eta_{\text {conc }} .=\mathrm{RT} / \mathrm{nF} * \ln \left(\mathrm{P}_{2} / \mathrm{P}_{1}\right)$

where $\mathrm{R}$ is gas constant, $\mathrm{T}$ is temperature, $\mathrm{F}$ is Faraday's constant, $\mathrm{n}$ is the number of electrons involved in the transfer, $\mathrm{P}_{1}$ is pressure when the current density is zero, and $\mathrm{P}_{2}$ is pressure at any current density.

This equation can be transformed into another useful relationship by considering that the current density of the fuel cell will be constrained by how fast the fuel can be supplied to the electrode. If $i_{L}$ is the limiting current density that corresponds to this maximum rate of fuel usage, and assuming that the pressure will fall linearly down to zero at the current density $i$, then pressure $\mathrm{P}_{2}$, at any current density $i$, would be $\mathrm{P}_{2}=\mathrm{P}_{1}\left(1-\mathrm{i} / \mathrm{i}_{\mathrm{L}}\right)$. By substituting this relation into Equation (8), the result is Nernst equation

$\Delta \mathrm{V}=-\mathrm{RT} / \mathrm{nF} * \ln \left(1-\mathrm{i} / \mathrm{i}_{\mathrm{L}}\right)$

Equation (9) gives voltage change caused by mass transport losses, (a negative sign indicates a voltage drop in a SOFC mode). The mass transport voltage drop for the entire cell at either of the electrodes at the current density (i) can reach the limiting current density $\left(i_{L}\right)$ causing the entire cell voltage to drop to zero. For this statement to be true, the actual value of the term denoted as "RT/nF" (which will vary with different fuel cell reactants) must be larger than the theoretical value.

\subsection{Ohmic (Resistance) Polarization}

Ohmic (resistance) polarization is caused by the electrical resistance encountered in transportation of ions and electrons through the electrolyte, electrodes, and current collectors. Ohmic (resistance) polarization should be separated from other polarization phenomena. When current flows through a cell, the resulting drop in voltage from the open circuit voltage $\left(\mathrm{V}_{\text {open }}\right)$ is defined as the cell polarization or overpotential at the specific current density.

Unlike the activation and concentration polarization, the ohmic polarization is a linear function of the cell current and increases over the entire range of current. The ohmic polarization refers to the voltage drop caused by the resistance to the flow of electrons and ions through the cell, which is fairly constant in a given cell. Typically, the ohmic polarization is caused by the electrolyte, the cell interconnectors, or 
bipolar plates. In the equation $\left(\mathrm{V}_{\mathrm{ohm}}=\mathrm{i} * \mathrm{r}\right.$ ), the current is often expressed as current density (amps per unit area, such as $\mathrm{mA} / \mathrm{cm}^{2}$ ). Therefore, corresponding resistance of a SOFC is the cell resistance normalized by its area $\left(\mathrm{k} \Omega \cdot \mathrm{cm}^{2}\right)$, and is called area specific resistance (ASR). From the cell polarization and corresponding current density, an ASR can be defined as

$\mathrm{ASR}=(\mathrm{E}-\mathrm{V}) / \mathrm{i}$

where $E$ can be either open circuit voltage potential $\left(E_{O C V}\right)$ or the ideal Nernst potential $\left(E_{N}\right)$, depending on whether one wants to (1) remove loss effects due to reactant leakage and variable reactant mixture supply and if one is focused on the cell material performance, or (2) focus on total cell performance (cell material and seals) [Gemmen et al. 2008].

Some methods for reducing this resistance include using:

- Electrodes with high electronic/ionic conductivity

- Appropriate bipolar plate/interconnect materials that are low in ohmic resistance and also complement the other cell component materials

- Thin, but structurally stable electrolyte with the ability to prevent shorting from one electrode to the other.

The important factor to remember about various polarization components is that they are not independent of each other. A change in partial pressure affects the concentration polarization and it will also affect the activation polarization. 


\section{LITERATURE REVIEW OF DEGRADATION AND RELATED PHENOMENA IN SOLID OXIDE CELLS}

As INL progressively increases the scale of electrolyzer systems by increasing the number of solid oxide cells and stacks, it is important to understand and address the causes of performance degradation in SOEC stacks. Unfortunately, there are not many studies in the published literature addressing degradation and related issues in SOECs. Even for SOFCs, the issues of degradation, aging, and longevity are topics of ongoing research. As thinner electrolytes with higher ionic conductivity are developed, the overall cell polarization losses are dominated by the electrochemical losses at the anodes and cathodes. Even though the solid oxide cells have several differences while operating in power generating (fuel cell) and electrolysis modes, the degradation mechanisms in the two cases may have some similarities. Therefore, the knowledge of degradation mechanisms in SOFCs can be a starting point for the SOECs and can offer some guidance in identifying the research areas. Because of this reason, some known degradation background in SOFCs is reviewed here.

Ni et al. [2006] have developed models for concentration overpotential in SOEC and SOFC as shown in Figure 7(a) and 7(b), respectively. The cathode (hydrogen electrode) in the electrolysis mode is termed as anode in the fuel cell mode. Similarly, the anode (oxygen electrode) in the electrolysis mode is termed as cathode in the fuel cell mode.

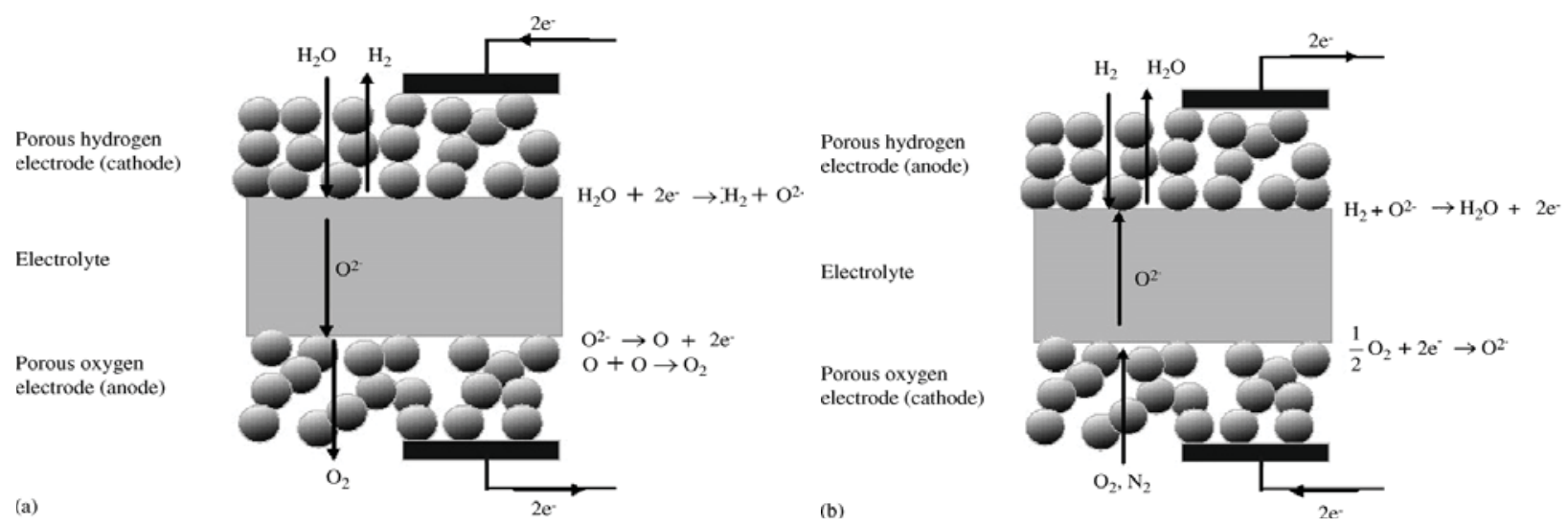

Figure 7. Operating mechanisms of solid oxide cells: (a) SOEC in electrolysis mode, and (b) SOFC in fuel cell mode [Ni et al. 2006].

A study by Simwonis et al. [2000] exposed a Ni (40 vol\%)/8 YSZ (60 vol\%) cermet anode at $1,000^{\circ} \mathrm{C}$ for 4,000 hours in a humidified $\mathrm{Ar} / 4 \% \mathrm{H}_{2} / 3 \% \mathrm{H}_{2} \mathrm{O}$ atmosphere. It was observed that the average Ni particle size increased from 2 to $2.57 \mu \mathrm{m}$ and the number of Ni particles decreased from 3,421 to 2,151. The main reason of $\mathrm{Ni}$ agglomeration is probably poor wettability characteristics between $\mathrm{Ni}$ and YSZ. The agglomeration of Ni particles during SOFC operation results in a reduction in electrochemical reaction sites, Ni-to-Ni contacts, and electronic current paths. This phenomenon decreases the electrical conductivity of the anode by $33 \%$. The reduction or prevention of agglomeration and sintering of Ni in the $\mathrm{Ni} / \mathrm{YSZ}$ cermet electrodes depend strongly on the microstructure of the Ni/YSZ cermet. A detailed and accurate description of the agglomeration and sintering in the Ni/YSZ cermet is rather difficult because of the complex nature of the system.

Tu and Stemming [2004] examined the aging mechanisms in anode, cathode, and interconnects in SOFCs. The performance of a SOFC depends on the polarization characteristics of a steam $/ \mathrm{H}_{2}$ electrode (anode, which depend on the electrode morphology. A homogeneous porous steam $/ \mathrm{H}_{2}$ electrode consisting of $\mathrm{Ni}$, and $\mathrm{YSZ}$ provides transport paths for electrons, oxide ions, and gases (steam and 
hydrogen), respectively. Shrinkage of electrode during firing results in lower porosity and decreased gas permeability. One fabrication technique proposed by Itoh [1995] is to divide YSZ powder into coarse and fine particles so that during sintering coarse YSZ particles are connected by a network of fine YSZ particles. This kind of microstructure prevents agglomeration and coarsening of Ni particles. Itoh tested a cell with this new design and noted that anodic overpotential remained at $\sim 0.05 \mathrm{~V}$ for $\sim 3,000 \mathrm{hrs}$, whereas with older anode design, the anodic overpotential increased to $0.6 \mathrm{~V}$ after $\sim 40$ hours of operation. While the manufacturing of SOFC and SOEC is not an INL objective, understanding a cell's performance in electrolysis mode is.

Jørgensen et al. [2000] performed durability tests on a SOFC with cathodes made from LSM and electrolytes made from YSZ. The tests, performed at $1,000^{\circ} \mathrm{C}$ in air for $2,000 \mathrm{hrs}$ but without current load, showed little or no degradation. However, the electrodes tested under the same conditions, but with a current density of $300 \mathrm{~mA} / \mathrm{cm}^{2}$ showed $\sim 100 \%$ increase in overpotential after 2,000 hours of testing. SEM examination of the electrodes with a current load showed that a large number of $\leq 1 \mu \mathrm{m}$ pores were formed on or near the interface between the electrode and the cathode. When ceramic oxide material is exposed to an electric field, local thermodynamics does not remain in equilibrium and the material composition changes locally. When a cation-deficient oxide material is exposed to an oxygen potential gradient, cations can migrate towards higher oxygen potential. The pores are likely to form at the interface with the lowest oxygen potential because this part of the interface is unstable. The pores will then move towards the interface with highest oxygen potential. In brief, it appears that sintering properties of cathode layers, the thermodynamic instability of the multicomponent ceramic mixture under operating (ionic and electric) conditions, etc., are the main reasons of increased polarization (overpotential) of the cathodes operating under load.

Recently, Virkar [2007] developed an overpotential model for a typical planar SOFC stack comprising several cells connected in series. He also gave the following argument in favor of developing a fundamental understanding of the degradation. In a stack, cell-to-cell characteristics should be as uniform as possible so that, at a given operating current, the voltage across each cell is essentially the same. If, because of some structural/fabrication flaws, the cells are not identical, the resistance and voltage drop will vary from cell-to-cell. In such a case, the remainder of the cells in the stack will drive the cell with higher resistance. In an extreme case, for the stack to continue operating, the voltage across a cell with higher resistance can even become negative, which can eventually lead to cell failure and increased local temperatures. This phenomenon can spread to adjacent cells as a domino effect. However, interpretation solely based on visual observations, without a sound theoretical basis for all the phenomena occurring in a cell, may be misleading. In a cell, observations are the aftermath result of some other critical damage to the cell that has already taken place. So the visual observation alone may not be able to show the "root cause" of the problem. Some of the likely reasons of cell degradation include small initial compositional inhomogeneities resulting in large changes in properties, the formation of local hot spots leading to local changes in microstructures and material properties, electrode delamination due to thermal cycling/rapid heating, reaction between electrode and electrolyte forming a high resistance layer, fuel and/or oxidant maldistribution, nonuniform oxidation of the interconnect, degradation of the seals, etc. In a normal SOFC, the (oxygen) ionic current is in a direction opposite to that of electronic current. However, if a cell has degraded to cause negative voltage, the direction of electron flow will reverse and both ionic and electronic currents will flow in the same direction. Virkar [2007] has developed a degradation model based on this premise, that is, a cell with higher resistance compared to the rest of the cells in the stack and operating under a negative voltage will be prone to degradation. Planar stacks are more likely to undergo such a degradation mechanism than tubular stacks. Therefore, the ability to measure voltage across each (planar) cell could help in preventing catastrophic failure by either performing preventive maintenance or shorting the bad cell. A similar degradation model of an SOEC can also offer some insight into the cell degradation phenomenon during the electrolysis mode. 
Per Virkar [2007], one of the principal modes of failure of solid-state electrolytes is related to the generation of high chemical potentials and corresponding ultra-high pressure of neutral species within the electrolyte. For example, in an oxygen ion conducting solid electrolyte such as YSZ, under some thermodynamic conditions, oxygen chemical potential within the solid electrolyte, $\mu_{\mathrm{O}_{2}}^{Y S Z}$, may exceed the chemical potential of gaseous oxygen, that is, under certain conditions, $\mu_{\mathrm{O}_{2}}^{Y S Z}>\mu_{\mathrm{O}_{2}}^{\mathrm{O}_{2} \text { electrode }}$. The chemical potential of any reactant is a function of its partial pressure, $\mu_{O_{2}}=f\left(p_{O_{2}}\right)$. Therefore, under

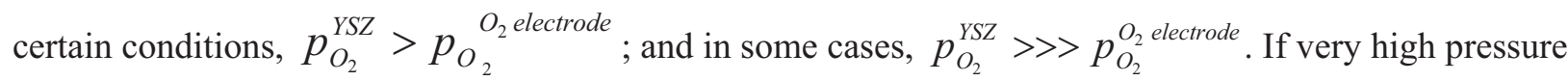
develops, it may result in electrode delamination. This increases the cell resistance and then degradation propagates.

Yokokawa et al. [2008] recently studied the chemical behavior of perovskite cathode/rare earth doped ceria interlayer/YSZ electrolyte multilayer structure and their relation to the cell's performance. To improve the performance of a cell at lower temperatures $\left(\sim 800^{\circ} \mathrm{C}\right)$, many changes in cell materials have taken place. However, these changes have also led to the following cell degradation problems:

- Metal interconnects give rise to new degradation mechanisms. One is increased resistance across oxide scales on both oxidizing and reducing sides. Another is cathode degradation (poisoning) caused by chromium oxide vapors, called chromium poisoning.

- Use of thermodynamically less stable materials $\left(\mathrm{La} / \mathrm{Sr} \mathrm{FeO}_{3}, \mathrm{Co} / \mathrm{Fe} \mathrm{O}_{3}\right)$ or rare earth doped ceria.

- At lower temperatures, metal carbonates will be formed.

- At lower temperatures, the electrochemical overpotential will increase when the same electrode materials are used.

Under the same operating conditions of temperature and current density, a SOFC and a SOEC are likely to have the same ohmic and activation overpotentials. Over the past few years, extensive research has been performed relating to SOFC. Yet SOFCs have not reached their complete commercial success because of problems relating to their degradation, longevity, and cost. Some of the degradation mechanisms include contact problems between adjacent cell components, microstructural deterioration (coarsening) of the porous electrodes, and blocking of the reaction sites within the electrodes. Contact problems include delamination of an electrode from the electrolyte, growth of a poorly (electronically) conducting oxide layer between the metallic interconnect plates and the electrodes, and lack of contact between the interconnect and the electrode. Examples of microstructural degradation are oxygen electrode sintering, carbon deposition, and sulfur or chromium poisoning. Delamination, caused by thermal cycling, increases ohmic resistance proportional to the delaminated area. The delaminated area also becomes inactive for electrochemical transport of ions across the electrode and the electrolyte. Chromium-based interconnect oxidation is another important mode that contributes to reducing electrical conductivity between the electrode and interconnect. Sometimes ceramic coatings are used to slow down the rate of oxidation and reduce the rate of chromia evaporation from the interconnects. It was also shown that the loss of performance resulting from interconnect detachment is less severe than that caused by electrode delamination because blocked transport of electrons can now easily move laterally in the electrodes as compared to ions being able to move within the electrolyte. The modeling exercise indicated that results of delamination are highly dependent on the inaccuracies in the knowledge of various cell parameters.

Thydén [2008] studied the microstructural degradation of Ni-YSZ anodes in SOFCs; a significant portion of the following discussion is based on Thydén's review.

The severe temperature and electrochemical conditions in a solid oxide cell create the need for special materials and pose important challenges to the longevity of the different cell components. The 
requirements of a solid oxide cell are to facilitate chemical reactions and remove reaction products with the lowest possible resistance. Therefore, in a cell, the density of reaction sites (sites per unit cell area) and transport paths should be maximized. For a solid oxide cell to be commercial viability, it should have a life time in the order of 40,000-50,000 hours. In order to facilitate such a long life time, the degradation rate must be very low in all components of the cell stack. It is therefore important to have a fundamental understanding of the degradation mechanism for each component. During operation, any change in the cell that causes blocked reaction sites or transport paths for species, will increase the overall cell resistance and thereby the degradation.

One important term used for describing reactions at both electrodes is the so-called triple-phase boundary (TPB). The TPB describes a site in the electrode where the electrochemical reaction takes place, shown as red dots in Figure 8 [Hauch 2007a]. At the steam $/ \mathrm{H}_{2}$ electrode, this site is where all three phases (Ni, YSZ, and gas) are in contact with each other. At the hydrogen electrode, supply of oxygen ions at YSZ, supply of gas in the pores, and means of transporting the electrons away from Ni are simultaneously required and thus at the TPB, the electrochemical reactions gets facilitated. In order to optimize the electrode performance, it is, therefore, important to maximize the electrochemical activity at the TPBs. For a reaction to take place at the TPB, the gas stream must flow through the pores, Ni must be connected to the interconnect plate, and the YSZ must be connected to the electrolyte either directly or via YSZ in the electrode. Changes in the electrode-electrolyte interfaces and grain boundaries are highly influential in the degradation of the cell. These interfaces not only provide the TPB, but are also active for mass transfer, diffusion, and segregation of species involved in the fuel cell reactions during operation. Microstructural changes in the interfacial regions, such as impurity segregation, will also affect the cell's performance.

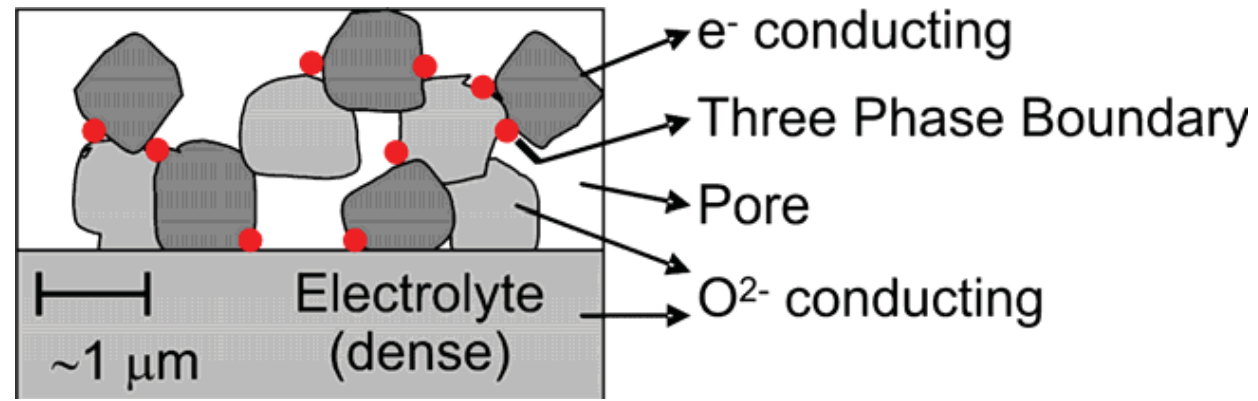

Figure 8. TPB in a solid oxide cell, shown as red dot, where reaction takes place [Hauch 2007a].

The problem of cell degradation also depends on the cells operating conditions, such as operating temperature, because of increased atomic activity at higher temperatures. It has also been shown that the overall degradation in the cell voltage is more closely correlated to the polarization than to the current density. At high polarization and/or low temperatures $\left(\sim 750^{\circ} \mathrm{C}\right)$, the oxygen electrode (fuel cell cathode) degradation can be dominant. However, at low polarizations and/or higher temperatures, both electrodes contribute equally to the cell degradation. From impedance measurement, it is difficult to assign any degradation phenomenon responsible for overall cell degradation, which implies the importance of correlating electrical measurements with cell microstructural changes.

Up to three separate responses have been reported from impedance measurements on a Ni-YSZ hydrogen electrode. At high frequency, one proposed response is due to charge transfer between Ni and YSZ and the limiting reaction step at the TPB is found. This response is seen to vary with operational temperature and is affected by thermal aging and microstructure of the anode. The other two responses arise at lower frequencies and are temperature dependant. These two responses have been assigned to gas diffusion and gas conversion, respectively, thus depending on the fuel/reaction product mixture in the vicinity of the TPB. 
The mismatch in thermal expansion characteristics of the cell's different layers is a major cause of stresses during thermal cycling occurring during fabrication and operation. In addition, the nonequilibrium chemical reactions throughout the cell also generate large thermal gradients, which in turn generate thermal stresses. These thermo-mechanical phenomena cause the degradation of the contact between adjacent cell components, namely the electrolyte-electrode and/or the interconnect-electrode interfaces. This degradation can lead to detachment of two adjacent layers, which results in reduced conductive paths available for electronic transport.

Another example of a degradation mechanism affecting SOFCs is the growth of an electrically insulating oxide layer between the interconnect plate and the electrodes, especially the fuel cell cathode. This leads to an increase in the cell ohmic resistance along the conductive path. The high temperature of operation promotes the kinetics of chromium oxide growth on the stainless steel interconnect plate. Extended periods of operation at high temperature and exposure to contaminants in the reactants also cause microstructural degradation. The electrochemical reactions in SOFCs are not restricted to the interface with the electrolyte, but take place within a few to tens of microns into the volume of the electrode. Therefore, a suitable electrode microstructure is of great importance in providing active surface area at the TPB for electrochemical reaction and sufficient porosity for gas species transport. Consequently, degradation mechanisms that affect electrode microstructure can compromise the cell's performance, stability, and durability. Some examples of microstructure degradation mechanisms given by Gazzari [2007] are as follows.

1. Sintering of the electrode microstructure, especially in a fuel cell anode. The fine-grained nickel in the porous fuel cell anode (hydrogen electrode) shows a tendency to agglomerate after long exposure to high temperatures. This results in loss of active surface area and changes in the porosity distribution, thereby lowering overall performance.

2. Poisoning of the fuel cell cathode microstructure with chromium products outgassed from the interconnect plates. This electrochemically driven degradation mode constitutes a major disadvantage of stainless-steel interconnects. The chromium rich compound deposits preferentially on the most electrochemically active sites, resulting in a loss of active area.

3. Carbon deposition in the fuel cell anode, This is an undesirable reaction that catalyzes coking in addition to hydrogen oxidation and deposits solid carbon on nickel, thus adversely affecting cell electrochemistry, diffusion, and structural integrity.

4. Sulfur poisoning of the fuel cell anode. Traces of $\mathrm{H}_{2} \mathrm{~S}$ or thiols (-SH, sulfhydryl) present in hydrocarbon fuels or hydrogen gets adsorbed on nickel as a molecular monolayer and blocks active reaction sites. Nonetheless, unlike the two mechanisms previously mentioned, sulfur desorbs upon reestablishment of a sulfur-free fuel stream, making it reversible at low concentrations. Furthermore, it does not affect the anode gas diffusion properties, at least at early stages of poisoning.

\subsection{Electrolyte Degradation}

In a SOFC, the electrolyte must remain stable under various electrochemical conditions. The oxygen ions must be able to diffuse from the oxygen electrode to the steam $/ \mathrm{H}_{2}$ electrode, where the oxygen ions can react with hydrogen. The electrolyte should not be porous so as to avoid permeation of gases across it, be as thin as possible to minimize ohmic losses, and have high ionic conductivity with a transference number for oxygen ions close to one and a transference number for electrons close to zero. The transference number of an ion is the fraction of the total current that is carried by that ion during electrolysis. Different ions carry different fractions of the current because different ions move at different speeds under the same potential gradient. The thickness of the electrolyte is dependent on whether the cell is electrolyte or electrode supported. Typically, the thickness of the electrolyte in an electrolyte-supported cell is in the 50 to $150 \mu \mathrm{m}$ range, yielding a high ohmic resistance and making the design suitable for 
higher temperature (approximately $1,000^{\circ} \mathrm{C}$ ) operation. The electrolyte in an electrode-supported cell can be thinner, in the range of 5 to $20 \mu \mathrm{m}$ and more suitable for lower temperature operation.

Thydén [2008] also discussed degradation of various components of SOFC, and part of that discussion is being included here. Table 1 lists some of the materials used in various components of a solid oxide cell. YSZ is commonly used as the electrolyte in solid oxide cells because it has the high ionic conductivity in the temperature range of 850 to $1,000^{\circ} \mathrm{C}$. However, at $1,000^{\circ} \mathrm{C}, 8 \mathrm{YSZ}$ ( $\left.8 \mathrm{~mole} \% \mathrm{yttria}\right)$ degrades more than other forms of YSZ, e.g., 9.5 YSZ, and after a few hundred hours of operation, the ionic conductivity becomes the same or lower than that of 9.5 YSZ. This degradation is shown to be due to precipitation and growth of tetragonal YSZ (t-YSZ) within the cubic YSZ (c-YSZ). Nevertheless, it can be concluded that a slightly higher concentration of $\mathrm{Y}_{2} \mathrm{O}_{3}$ or an alternative dopand would be beneficial for the conductivity and phase stability of c-YSZ. At $1,000^{\circ} \mathrm{C}$; a Mn content above $2 \mathrm{~mol} \%$ is shown to have a stabilizing effect on $7.9 \mathrm{YSZ}$, while a lower Mn content does not. At $850^{\circ} \mathrm{C}$, up to $5 \mathrm{~mol} \%$ of $\mathrm{Mn}$ in 7.9 YSZ does not stabilize the conductivity, but instead, is detrimental for the overall conductivity [Appel et al. 2001]. It shows that for lower temperature fuel cells, Mn addition should be avoided. During the annealing of cubic stabilized $\mathrm{Y}_{2} \mathrm{O}_{3}-\mathrm{ZrO}_{2}$, some impurities like yttrium, silicon, sodium, iron, and potassium tend to segregate and affect electrochemical reactions in the cells.

\subsection{Steam/Hydrogen Electrode Degradation}

The steam $/ \mathrm{H}_{2}$ electrode (anode in fuel cell mode, cathode in electrolysis mode) material must be stable in reducing atmospheres and must have high conduction of electrons. In addition, the porosity of this electrode must allow the transport of the fuel (hydrogen) to the electrolyte-electrode interface where fuel oxidation takes place, and also allow the products of the oxidation to move away from the interface region. As previously mentioned, this transfer takes place at the surface of the hydrogen electrode, and therefore, surface area becomes a critical design parameter. The porosity of the electrodes, in effect, increases the surface area by providing more potential reactant sites. The atmosphere is reducing, thus metals are often used, such as nickel in $\mathrm{Ni}-\mathrm{ZrO}_{2}$. In this combination, the nickel component acts as a catalyst to hydrogen oxidation and hydrocarbon fuel reforming; the zirconia keeps the nickel from sintering and becoming coarse at the high temperatures, which could reduce the porosity and surface area of the anode. A coarsening of Ni also results in a reduction of available TPBs and loss of electrical conductivity of the steam $/ \mathrm{H}_{2}$ electrode. Temperature and other operating conditions are the most important parameter for Ni coarsening. Nickel has a larger thermal expansion coefficient than that of YSZ, so the zirconia tends to lower the thermal expansion of the hydrogen electrode.

During a fuel cell operation, the steam $/ \mathrm{H}_{2}$ electrode will encounter a gradient in concentration of reactants (fuel gas $\mathrm{H}_{2}$ and $\mathrm{H}_{2} \mathrm{O}$ ) along the reactant flow path. Thus part of $\mathrm{H}_{2}$ will be continually replaced by $\mathrm{H}_{2} \mathrm{O}$ as the gas mixture flows across the cell. Because the reaction only takes place close to the electrode surface from where $\mathrm{H}_{2} \mathrm{O}$ diffuses through the electrode support to the gas stream, a similar gradient is also expected to be present in the direction towards the electrode-electrolyte interface.

Hagen et al. [2006] reported that the hydrogen electrode degrades more at higher temperatures. They attributed the hydrogen electrode degradation to $\mathrm{Ni}$ coarsening at $750^{\circ} \mathrm{C}$ and $850^{\circ} \mathrm{C}$, and also to $\mathrm{Ni}$ loss from local areas of the electrode close to the electrode interface at $850^{\circ} \mathrm{C}$. They mention $\mathrm{Ni}$ evaporation as one of the possible mechanisms for the Ni loss. Gubner et al. [1997] showed that impurities tend to segregate to the surface of YSZ. This segregation will inevitably affect the hydrogen electrode and the interface between Ni and YSZ. Several studies have reported the influence of impurities on the TPB of Ni-YSZ electrodes, including: Jensen [2002]; Liu, Primdahl, and Mogensen [2003]; Liu and Jiao [2005]; and Høgh [2005]. The segregation of impurities to the Ni-YSZ interface is shown to increase the polarization resistance for the anode reaction. Another degradation problem for the Ni-YSZ electrode is the reoxidation (redox) behavior. If a Ni-YSZ electrode is subjected to an oxidizing atmosphere at a high temperature, $\mathrm{Ni}$ will oxidize to form $\mathrm{NiO}$, which can result in a greater risk of mechanical failure of the 
YSZ structure [Klemensø et al. 2005 and Klemensø and Morgensen 2007]. It is therefore important to have a continued stable fuel gas supply and to avoid oxidation of the hydrogen electrode.

\subsection{Oxygen Electrode and Interconnect Degradation}

The oxygen electrode functions on the oxygen (usually air) side of the solid oxide cell in an oxidizing environment, and oxygen is reduced to oxygen ions by removing electrons. Because this electron transfer takes place on the surface of the electrode, the surface area is a very important parameter of the design. In fact, the rate at which this transfer occurs is designated in the units of current per unit area. The desired material properties include high electronic conductivity, thermal expansion compatibility with adjoining components, and adequate porosity to provide a sufficient electrode-electrolyte interfacial region for electrochemical reaction. The oxygen electrode material must also provide a good interface without forming troublesome reactions with other materials. Many materials are being considered, such as $\left(\mathrm{La}_{0.9} \mathrm{Sr}_{0.1} \mathrm{MnO}_{3}\right)$ as listed in Table 1. Unfortunately, testing has uncovered a variety of these deleterious reactions, such as manganese $(\mathrm{Mn})$ diffusing with the zirconia and forming an electronic shorting throughout the electrolyte or the oxygen electrode material reacting with the zirconia electrolyte to form a compound $\left(\mathrm{La}_{2} \mathrm{Zr}_{2} \mathrm{O}_{7}\right)$ that is electrically insulating (Khandkar, Elangovan, and Hartvigsen, 1996). To overcome these problems, some researchers have even included an interlayer (that acts like a buffer) during fabrication to inhibit these types of reactions between the electrolyte and the cathode.

In the planar design, an interconnect (bipolar plate) connects the anode of one cell to the cathode of an adjoining cell in a stack. The main purpose of the interconnect is to separate and distribute the fuel and oxidant gases to the electrodes. Some of the desirable properties of an interconnect plate are similar thermal expansion coefficient as adjoining components, high mechanical strength, and impermeability to gas to prevent direct chemical combustion of the fuel, while maintaining chemical compatibility with other cell components. In addition, it must be stable over the entire range of operating oxygen partial pressure and have high electronic conductivity in air and fuel, while exhibiting no oxygen ion conductivity. Both ceramic and metal interconnects have been investigated. Some metals have been used because of their machinability and thermal transfer characteristics; however, some of the metals being used, such as Inconel, may be cost prohibitive over the long term. Ferrite stainless steels are often the preferred choice of material for the interconnect plates. At high temperatures and long-term operation, oxide layers are formed on the surface of the metallic interconnect, resulting in an increase of the electrical resistance between stacked cells. In addition, volatile $\mathrm{Cr}$ species are deposited over the oxide layer in oxidizing atmospheres. The $\mathrm{Cr}$ species can deposit at the oxygen electrode-electrolyte interface, causing a severe loss of cell performance [Zhen et al. 2007]. Tucker et al. [2006] gave evidence of surface diffusion of $\mathrm{Cr}$ species through the physical contact between interconnect and oxygen electrode.

LSM and YSZ react to form lanthanum zirconate (LZO) at the oxygen electrode-electrolyte interface. The presence of LZO increases the electrode resistance and can lead to delamination of the electrodeelectrolyte interface [Heneka and Ivers-Tiffée 2005]. The LZO formation is known to be dependent on operating conditions, sintering temperature, and the composition of the LSM phase [Mitterdorfer and Glauckler 1998].

Various degradation mechanisms affect the cell performance such as a loss of available voltage at constant current density or a drop in current density flow at constant voltage. Generally, single cell and cell stacks are tested and their performance is measured over time. As a general observation, the performance (output) usually decreases over a period of time, but it is not possible to identify a specific degradation mechanism or combination of mechanisms by observing only changes to the current-voltage behavior of the cell. There is thus a need to develop a diagnostic technique that will allow the identification of specific degradation mechanisms of the cells in a minimally invasive way. Such a technique would be a useful tool for diagnosis of both a cell in service or under development. Such a technique can also save the disassembly time required for a direct observation. In the case of reversible 
degradation, the method would indicate the possibility to correct the problem while the cell is in operation. In the case of irreversible degradation, the method would aid in identifying the specific cause of failure of a component that needs replacement, so that operating conditions or cell or stack materials or designs could potentially be adjusted in subsequent tests/operation to minimize further degradation. At a research stage, a diagnostic tool of this kind would be a useful complement to post-mortem microstructural observation. Electrochemical impedance spectroscopy is a minimally invasive tool that can provide significant information about electrochemical systems.

Guan et al. [2006] tested reversible solid oxide cell stacks for over 100 hours, alternating between fuel cell and electrolysis mode. Figure 9 shows cell degradation in terms of ASR increase for three cells. The higher degradation showing for Cell 3 may be the result of increased contact resistance between electrodes and interconnects. The microstructure of another stack was examined after a test run with secondary electron microscopy; the results are shown in Figure 10. Delamination was observed between electrolyte and samaria-doped ceria (SDC) barrier layer and barrier layer and oxygen electrode, which can cause performance degradation. They also showed that performance of various oxygen electrodes (LSM, LSF, and LSCF) was in the order LSCF > LSF > LSM-YSZ, however, degradation of the LSCF electrode was probably more than other electrodes. Cell degradation was higher with stainless steel interconnects than with gold interconnects. However with coated stainless steel interconnects, degradation was reduced in half. In general, they observed degradation rates of $0.2-0.3 \mathrm{ohm}-\mathrm{cm}^{2} / 1,000 \mathrm{hrs}$.

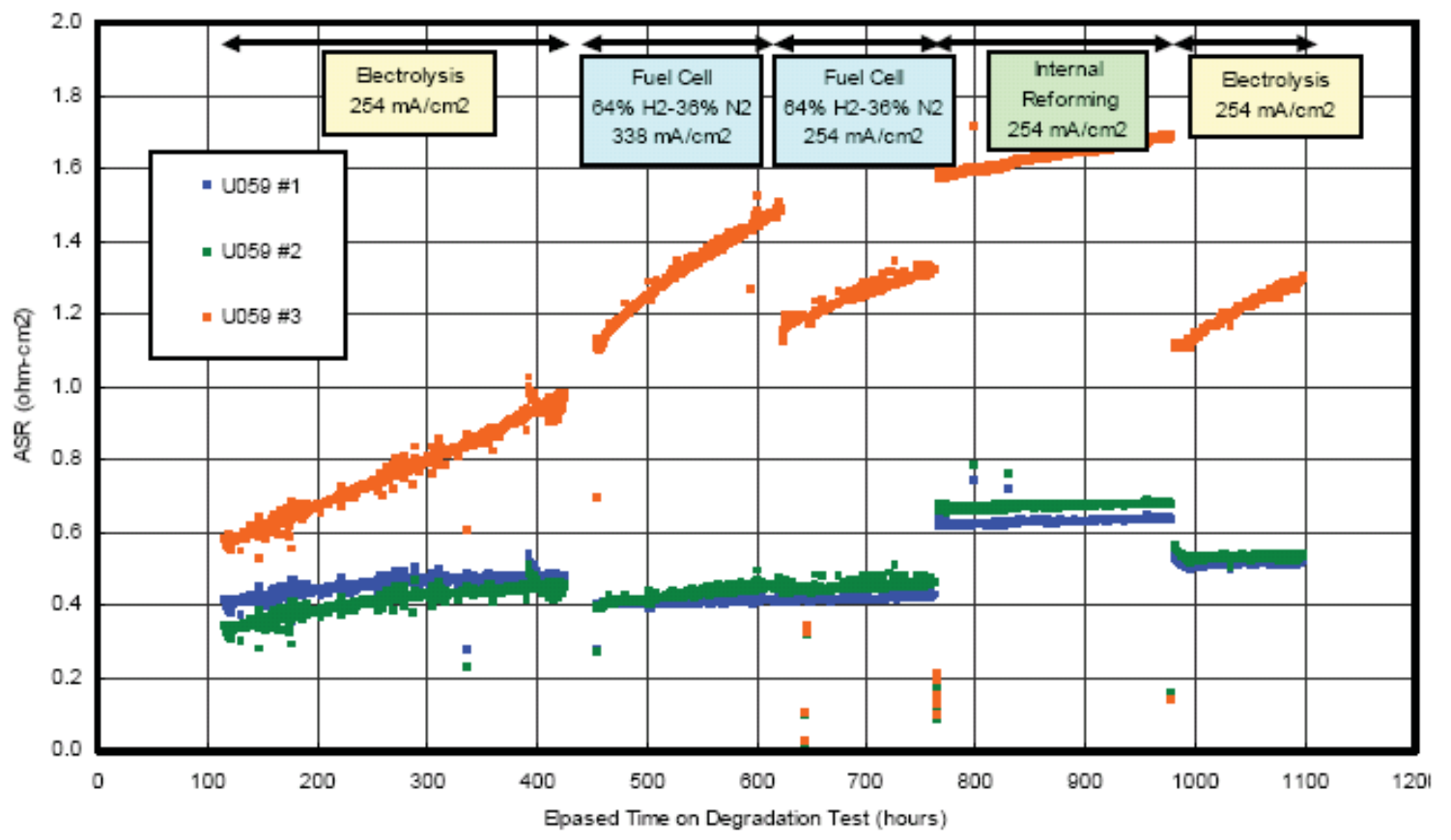

Figure 9. Individual cell performance in a three-cell stack operating at $800^{\circ} \mathrm{C}$ for $>1,000$ hours [Guan et al. 2006]. 

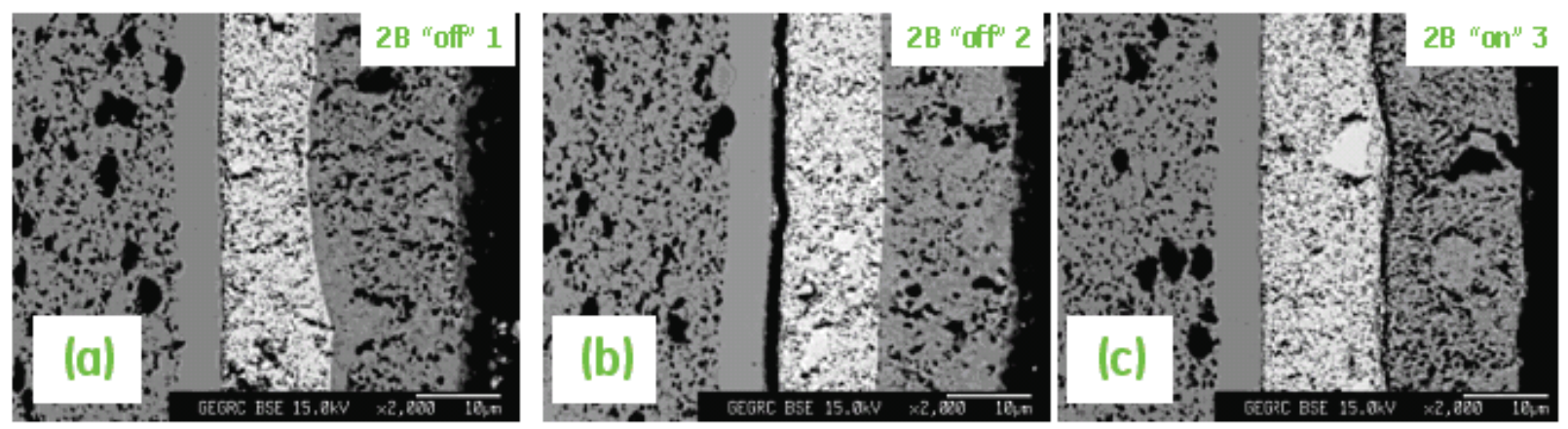

Figure 10. Microstructure of a typical cell stack (from left to right: fuel electrode, electrolyte, barrier layer, and oxygen electrode); (a) a typical cross-section, (b) cross-section showing delamination between electrolyte and barrier layer, and (c) cross-section showing delamination between barrier layer and oxygen electrode [Guan et al. 2006].

Hauch et al. [2005, 2007a, 2007b, and 2008] also tested solid oxide cells in the electrolysis mode at the Risø National Laboratory at temperatures from $650-950^{\circ} \mathrm{C}, \mathrm{p}\left(\mathrm{H}_{2} \mathrm{O}\right) / \mathrm{p}\left(\mathrm{H}_{2}\right)$ from $0.99 / 0.01$ to $0.30 / 0.70$, and current densities from $-0.25 \mathrm{~A} / \mathrm{cm}^{2}$ to $-2 \mathrm{~A} / \mathrm{cm}^{2}$ (negative current represents electrolysis mode). The cells were made from 10-15 $\mu \mathrm{m}$ thick $\mathrm{H}_{2}$-electrode of $\mathrm{Ni} / \mathrm{YSZ}$, supported by a $\sim 300 \mu \mathrm{m} \mathrm{Ni/YSZ} \mathrm{layer,} \mathrm{a}$ $10-15 \mu \mathrm{m}$ YSZ electrolyte, and a 15-20 $\mu \mathrm{m}$ thick LSM-YSZ composite $\mathrm{O}_{2}$-electrode. The SOECs were characterized by current-voltage (i-V) curves and electrochemical impedance spectroscopy (EIS). The tested SOECs showed ASRs of $0.26 \Omega-\mathrm{cm}^{2}$ at $850^{\circ} \mathrm{C}$ and $0.17 \Omega-\mathrm{cm}^{2}$ at $950^{\circ} \mathrm{C}$ as obtained from the i-V curves and a current density of $-3.6 \mathrm{~A} / \mathrm{cm}^{2}$ at a cell voltage of $1.49 \mathrm{~V}$ and $950^{\circ} \mathrm{C}$.

Hauch [2007a] summarized the general observations of the SOEC tests as (1) a short-term passivation (reduction of the reactivity by electrochemical polarization) in the first few hundred hours, (2) an activation, and (3) a subsequent long-term degradation. The transient phenomenon (passivation/activation) was shown to be on the albite glass sealing with a $\mathrm{p}\left(\mathrm{Si}(\mathrm{OH})_{4}\right)$ of $1 \cdot 10^{-7} \mathrm{~atm}$. Upon reduction of steam in the $\mathrm{H}_{2}$ electrode, in the few microns closest to the electrolyte, the equilibrium between $\mathrm{Si}(\mathrm{OH})_{4}$ and silica is shifted towards formation of silica leading to a contamination of the TPBs of the electrode. Long-term degradation of $2 \% / 1,000$ hours was obtained at $850^{\circ} \mathrm{C}, \mathrm{p}\left(\mathrm{H}_{2} \mathrm{O}\right) / \mathrm{p}\left(\mathrm{H}_{2}\right)=$ $0.5 / 0.5$ and current density of $-0.5 \mathrm{~A} / \mathrm{cm}^{2}$, whereas the degradation rate increased to $6 \% / 1,000$ hours at $950^{\circ} \mathrm{C}, \mathrm{p}\left(\mathrm{H}_{2} \mathrm{O}\right) / \mathrm{p}\left(\mathrm{H}_{2}\right)=0.9 / 0.1$ and current density of $-1.0 \mathrm{~A} / \mathrm{cm}^{2}$. The long-term degradation for the SOECs was more pronounced than for SOFCs of similar composition. Both the short-term passivation and the long-term degradation appear mainly to be related to processes in the $\mathrm{H}_{2}$-electrode.

Micrographs taken using SEM showed that changes occurring in Ni particle size are not the main cause of degradation. Energy dispersive spectroscopy in combination with transmission electron microscopy (TEM) and scanning TEM revealed that glassy phase impurities accumulated at the TPBs after the test. The impurities were observed both as rims around Ni particles and as more regularly shaped phases at the TPBs, typically in the size range of 50-500 $\mathrm{nm}$. The impurities are silicates, alumina silicates, and in some cases sodium alumina silicates. It is believed that the degradation of the SOECs relates strongly to these impurity phases. Impedance spectra showed that the main part of the irreversible degradation is caused by increased losses in the hydrogen electrode. Postmortem (SEM) analysis showed that there was a significant microstructural change at the $\mathrm{H}_{2}$-electrode-electrolyte interface. A 2-4 $\mu \mathrm{m}$ thick dense layer of Ni and YSZ was formed at the interface caused by relocation of Ni particles.

Hauch [2007a] suggested simple possible mechanisms leading to degradation at the steam/ $\mathrm{H}_{2^{-}}$ electrode based on several previous publications. The four possible reaction scenarios shown in Figure 11 are based on various possibilities proposed by other researchers and cited by Hauch [2007a], but several 
intermediate reactions including adsorbed $\mathrm{OH}$ and vacancies are not shown. In Figure 11(a), the inlet reactants at the steam $/ \mathrm{H}_{2}$-electrode reach near the TPB via the pores in the $\mathrm{H}_{2}$-electrode and the reaction at the electrode proceeds via adsorption of $\mathrm{H}_{2} \mathrm{O}$ on the YSZ surface in the vicinity of the TPB. Hydrogen either diffuses through the YSZ and Ni to a vacant Ni site, and $\mathrm{H}_{2}(\mathrm{~g})$ desorbs or hydrogen diffuses on the surface of the YSZ and $\mathrm{Ni}$ (dashed lines). Another possible reaction based on the assumption that $\mathrm{H}_{2} \mathrm{O}$ will adsorb on the YSZ surface is given in Figure 11(b). This mechanism involves conduction of electrons in the YSZ and Ni, and release of $\mathrm{H}_{2}(\mathrm{~g})$ as shown in Figure 11(b). Figure 11(c) illustrates a mechanism with adsorption of $\mathrm{H}_{2} \mathrm{O}$ on the $\mathrm{Ni}$ surface. This reaction mechanism has been questioned by some researchers because (a) in catalysis literature, adsorbed hydrogen is indeed very fast moving on $\mathrm{Ni}$ surfaces and it seems unlikely that diffusion of hydrogen adsorbed on the Ni surface should be rate determining and (b) most researchers report more than one, typically three, arcs in the impedance spectra obtained on YSZ-Ni cermets and the mechanism suggested in Figure 11(c) does not seem to be able to account for that. In Figure 11(d), an ideal reaction mechanism is shown. Here, $\mathrm{H}_{2} \mathrm{O}$ is assumed to be adsorbed at the TPB and only hydrogen has to diffuse on the Ni surface and is desorbed as $\mathrm{H}_{2}(\mathrm{~g})$. In reality an unlimited number of TPBs are not available and the actual number of TPBs will set an upper limit for the reaction mechanism shown in 11(d), especially at high current densities.

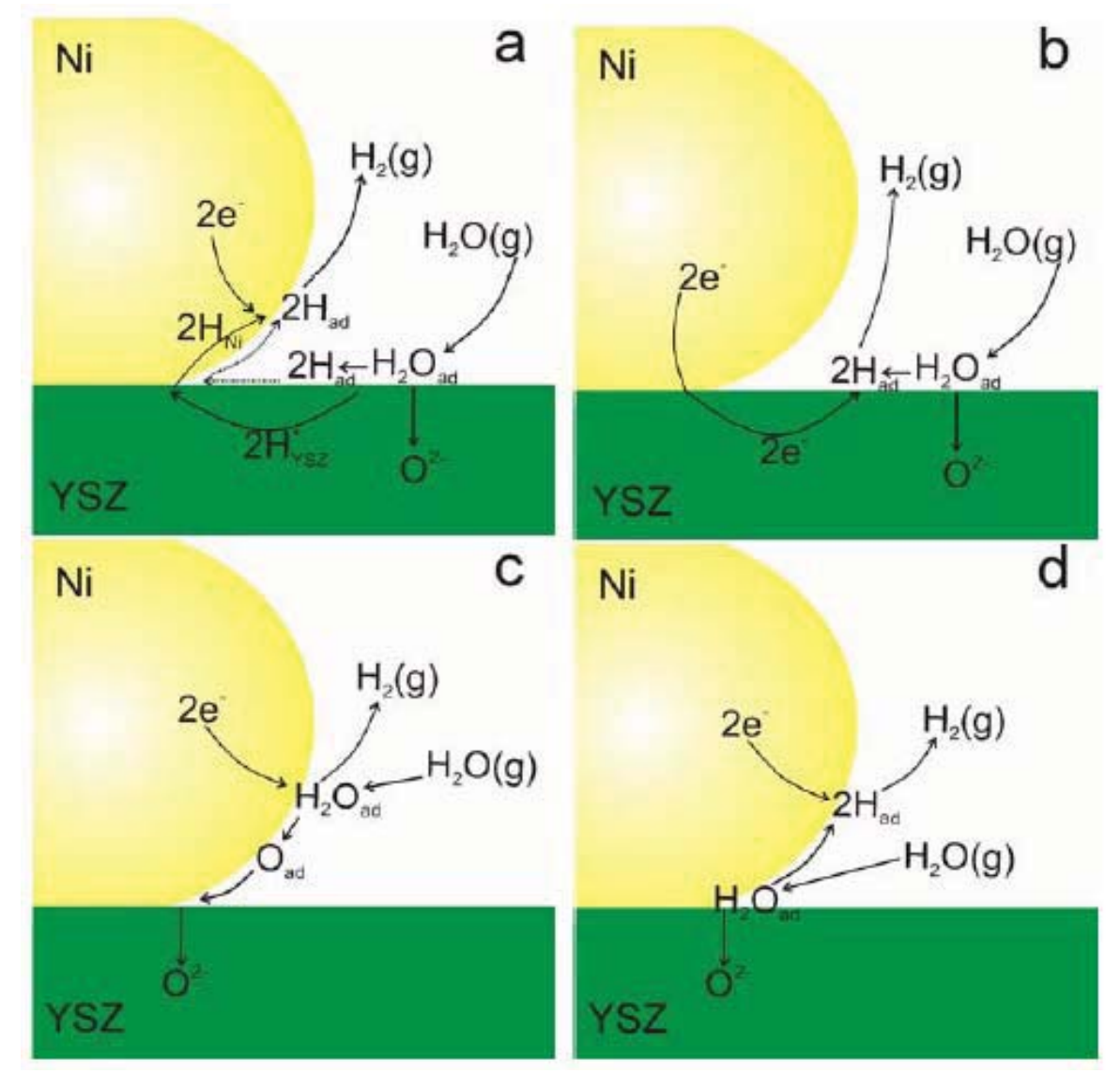

Figure 11. Possible simple reaction mechanisms at the steam $/ \mathrm{H}_{2}$-electrode in a SOEC [Hauch 2007a]:

(a) adsorption of $\mathrm{H}_{2} \mathrm{O}$ on the YSZ surface and proton diffusion on the surface or in the bulk of YSZ,

(b) adsorption of $\mathrm{H}_{2} \mathrm{O}$ on the YSZ surface and electronic conduction in YSZ is assumed,

(c) Adsorption of $\mathrm{H}_{2} \mathrm{O}$ on the Ni surface and diffusion of oxygen on the Ni surface, and

(d) $\mathrm{H}_{2} \mathrm{O}$ adsorbed at the TPB and hydrogen diffusion on the Ni surface. 
In the above reactions mechanisms, the presence of impurities at the grain boundaries is not included, which are always there. Levels of impurities in the raw materials and their chemical composition upon segregation to the grain boundaries may play an important role in the electrode reaction mechanisms and be part of the discrepancy in the results reported on the reaction mechanisms for the $\mathrm{H}_{2}-\mathrm{H}_{2} \mathrm{O}-\mathrm{Ni}-\mathrm{YSZ}$ system. Even in recent reviews, a complete and well understood electrode reaction mechanism at anodic polarization for the $\mathrm{H}_{2}-\mathrm{H}_{2} \mathrm{O}$ reactants and YSZ-Ni electrode system does not exist, and even less is known about the reaction mechanism under cathodic polarization.

Hauch [2007a] also showed that during first 100-200 hours of SOEC testing, short-term passivation occurs, which was an effect of the albite glass used as sealing material. The ohmic resistance remained nearly unaffected during the short term passivation period, but polarization resistance increased and decreased during the same period. Long-term degradation of the SOEC showed a linear trend in time. The degradation rates were $2 \% / 1,000$ hours at $850^{\circ} \mathrm{C}, \mathrm{p}\left(\mathrm{H}_{2} \mathrm{O}\right)=0.5 \mathrm{~atm}$ and $-0.5 \mathrm{~A} / \mathrm{cm}^{2}$ and $6 \% / 1,000$ hours at $950^{\circ} \mathrm{C}, \mathrm{p}\left(\mathrm{H}_{2} \mathrm{O}\right)=0.9 \mathrm{~atm}$ and $-1.0 \mathrm{~A} / \mathrm{cm}^{2}$. These degradation rates are significantly higher than those for similar cells tested in fuel cell mode $\left(<2 \% / 1,000\right.$ hours at $950^{\circ} \mathrm{C}$, and $\left.-1.7 \mathrm{~A} / \mathrm{cm}^{2}\right)$. EIS results showed that change in impedance spectra due to gas variation experiments before and after electrolysis operation verifies that the main passivation of the SOECs is caused by loss of performance in the $\mathrm{H}_{2}$ electrode. SEM investigations of the Ni particle size distribution showed that the Ni size distribution for SOEC changed compared to those for reference cells. However, these changed Ni distribution were similar to those obtained for fuel cells tested for the same time period. Hence, a change in Ni particle size distribution is not the main reason for the performance degradation of the SOECs. Silicon containing impurities were observed to segregate to the innermost few microns of the $\mathrm{H}_{2}$-electrode closest to the electrolyte. These impurities were also found as rims around the Ni particles. These impurities that diffused to and accumulated at the TPBs of the $\mathrm{H}_{2}$-electrode were thought to be the main reason for the degradation of the SOECs. 
Table 2 lists many failure modes in a SOFC, degradation mechanisms, degradation activation agents, and parameters to be measured to detect degradation as given by Koehler et al. [2001].

Table 2. Causes of degradation, failure mode, and needed measurements [Koehler et al. 2001]

\begin{tabular}{|c|c|c|c|c|}
\hline $\begin{array}{c}\text { Component } \\
\text { Part }\end{array}$ & $\begin{array}{c}\text { Failure Modes } \\
\text { (visual } \\
\text { symptoms) } \\
\end{array}$ & $\begin{array}{l}\text { Degradation } \\
\text { Mechanisms } \\
\text { (causes of the } \\
\text { damage) }\end{array}$ & $\begin{array}{l}\text { Degradation } \\
\text { Stressors } \\
\text { (mechanism } \\
\text { activation agents) }\end{array}$ & $\begin{array}{c}\text { Mechanism and Stressor } \\
\text { (What should be measured to } \\
\text { detect degradation?) }\end{array}$ \\
\hline Electrolyte & $\begin{array}{l}\text { Cracked, } \\
\text { warpage/bowing } \\
\text { surface fractures } \\
\text { Cracked, } \\
\text { warpage/bowing } \\
\text { surface fractures } \\
\text { Cracked, } \\
\text { warpage/bowing } \\
\text { surface fractures }\end{array}$ & $\begin{array}{l}\text { High thermal } \\
\text { stress, reduced } \\
\text { strength of } \\
\text { material } \\
\text { Mechanical stress } \\
\text { (materials are not } \\
\text { flat) } \\
\text { High stress }\end{array}$ & $\begin{array}{l}\text { Thermal coefficient } \\
\text { mismatch with } \\
\text { another material, } \\
\text { deleterious material } \\
\text { interactions } \\
\text { Pressure too high on } \\
\text { cell stack or material } \\
\text { too brittle } \\
\text { Sealing material } \\
\text { contacted electrolyte }\end{array}$ & 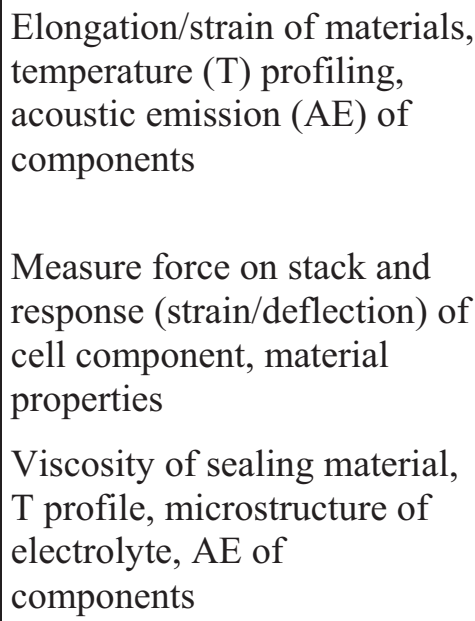 \\
\hline Cathode & $\begin{array}{l}\text { Low power } \\
\text { output, degrading } \\
\text { performance }\end{array}$ & $\begin{array}{l}\text { High activation } \\
\text { polarization }\end{array}$ & $\begin{array}{l}\text { Low } \mathrm{O}_{2} \\
\text { activity/pressure at } \\
\text { site }\end{array}$ & $\begin{array}{l}\mathrm{P}\left(\mathrm{O}_{2}\right) \text { at interface, gas } \\
\text { chromatography or } \mathrm{p}\left(\mathrm{O}_{2}\right) \\
\text { sensor, impedance } \\
\text { spectroscopy }\end{array}$ \\
\hline Anode & $\begin{array}{l}\text { Low power } \\
\text { output, degrading } \\
\text { performance } \\
\text { Low power } \\
\text { output, degrading } \\
\text { performance }\end{array}$ & $\begin{array}{l}\text { High activation } \\
\text { polarization } \\
\text { High } \\
\text { concentration } \\
\text { polarization }\end{array}$ & $\begin{array}{l}\text { Low fuel activity, } \\
\text { low pressure at site } \\
\text { Fuel leaks/reactants } \\
\text { not making it to the } \\
\text { site }\end{array}$ & $\begin{array}{l}\mathrm{p}(\text { fuel) at interface, } \mathrm{GC}, \mathrm{T} \\
\text { profile } \\
\text { Fuel utilization, differential } \\
\text { pressure (dp) of fuel and } \mathrm{O}_{2} \mathrm{~T} \\
\text { profile, IS }\end{array}$ \\
\hline Interface & Cracking & Heat gradient & $\begin{array}{l}\text { Fuel leaks/fuel took } \\
\text { alternate path or the } \\
\text { path is obstructed }\end{array}$ & $\begin{array}{l}\text { Thermal profile across the } \\
\text { cell, volumetric check of } \\
\text { exhaust gasses, fuel flow } \\
\text { balance }\end{array}$ \\
\hline Interconnect & Cracking & $\begin{array}{l}\text { Heat gradient at } \\
\text { the interface }\end{array}$ & $\begin{array}{l}\text { Fuel took alternate } \\
\text { path or the path is } \\
\text { obstructed }\end{array}$ & $\begin{array}{l}\text { Thermal profile across the } \\
\text { cell; fuel flow balance }\end{array}$ \\
\hline
\end{tabular}

Another such summary of the main degradation mechanisms is given by Blum et al. [2007] and is listed in Table 3. 
Table 3. Main degradation mechanisms in a SOFC [Blum et al. 2007].

\begin{tabular}{|l|l|l|}
\hline \multicolumn{2}{|c|}{ Components of a solid oxide cell (in power generation, i.e., fuel cell, mode) } \\
\hline $\begin{array}{l}\text { Three phase boundary reduction by: } \\
\text { - Cr poisoning } \\
\text { - Particle sintering }\end{array}$ & $\begin{array}{l}\text { Phase instabilities } \\
\text { Interdiffusion }\end{array}$ & $\begin{array}{l}\text { Ni agglomeration } \\
\text { Sulphur poisoning } \\
\text { Cracking by reoxidation }\end{array}$ \\
\hline $\begin{array}{l}\text { Phase change } \\
\text { Interdiffusion }\end{array}$ & & Interdiffusion \\
\hline $\begin{array}{l}\text { Contact degradation } \\
\text { Resistivity increase } \\
\text { Cr transport }\end{array}$ & $\begin{array}{l}\text { Contact loss by: } \\
\text { - Sintering } \\
\text { - Electrical resistance of scales }\end{array}$ & - Seal swelling \\
\hline - Scale spallation & Temperature gradients \\
- Inner oxidation & Resistivity increase \\
\hline Mechanical distortion & & Interconnect: \\
\hline
\end{tabular}

\subsection{INL Degradation Tests on SOECs}

O'Brien et al. [2009] recently summarized INL's test results on HTE tests using solid oxide cells including observations of long-term performance degradation of SOECs. Note that INL cells and stacks utilize scandia-stablized zirconia (ScSZ) electrolyte-supported cells, which do not necessarily represent the state-of-the-art in cell design. The scandia dopant level in these cells was only about $6 \mathrm{~mol} \%$, which is not high enough to be considered fully stabilized. In addition, $\mathrm{ScSZ}$ with dopant levels less than $10 \%$ have been shown to exhibit an aging effect with annealing at $1,000^{\circ} \mathrm{C}$ [Haering et al. 2005].

Long-term degradation in button cell tests can only be due to degradation of the electrodes, the electrolyte, or electrode-electrolyte delamination. There are no effects associated with corrosion, contact resistance, flow fields, or interconnects because these components are not present. The results of a longterm, button-cell test are presented in Figure 12. This figure shows the ASR of a button cell plotted as a function of time over the duration of a 1,100-hour test. The ASR increases quite rapidly at the start of the test from an initial value of $\sim 0.6 \mathrm{Ohm} \mathrm{cm}^{2}$ to a value of $0.9 \mathrm{Ohm} \mathrm{cm} \mathrm{cv}^{2}$ over about 40 hours. Between 100 and 1,100 hours, the ASR increases from $0.98 \mathrm{Ohm} \mathrm{cm}^{2}$ to $1.33 \mathrm{Ohm} \mathrm{cm}^{2}$. If the initial 100 hours is considered to be a cell conditioning period, the degradation rate over the following 1,000 hours is about $35 \%$. This is obviously an unacceptable rate of degradation. As a comparison, the Phase-III SECA target degradation rate is $0.1 \% / 1,000$ hours. Several companies are currently coming very close to meeting that target in the SOFC mode of operation. 


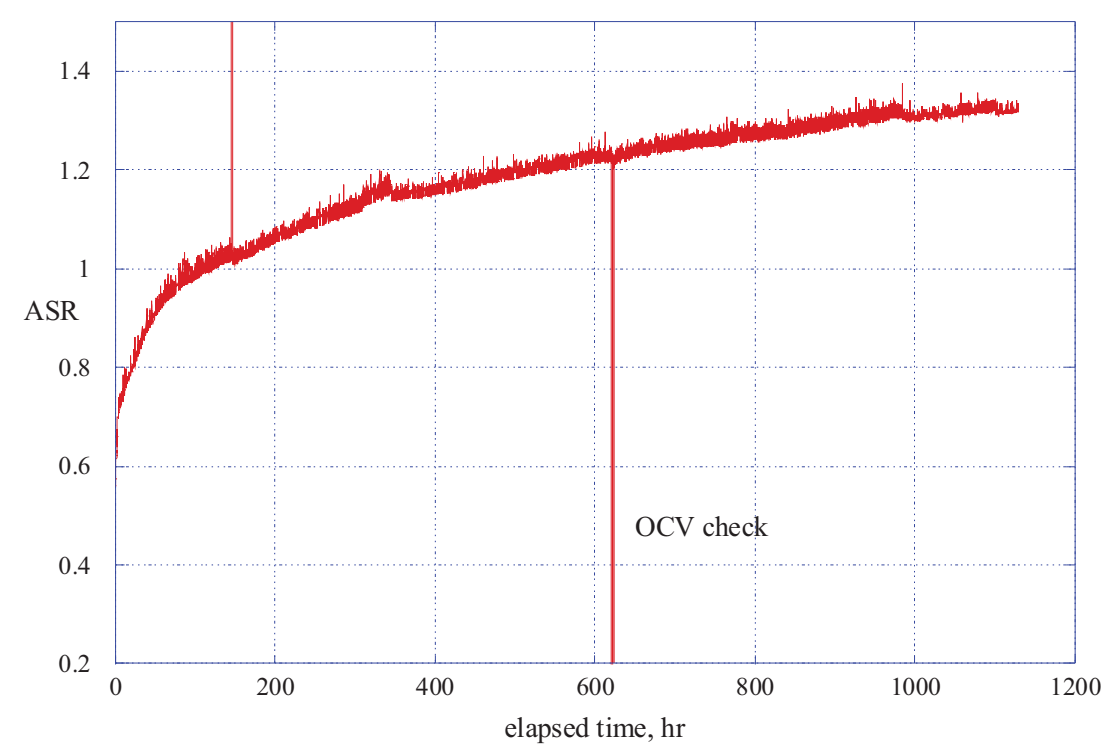

Figure 12. Area-specific resistance of a button cell as a function of time for the 1,100-hour test.

Performance degradation results with a 25-cell SOEC stack tested for 1,000 hours at INL were presented by O'Brien et al. [2007] and are shown in Figures 13 and 14. Figure 13 plots the stack ASR as a function of time for the 1,000 hours. The furnace temperature was increased from 800 to $830^{\circ} \mathrm{C}$ over an elapsed time of 118 hours, resulting in a sudden drop in ASR. The increase in ASR with time represents degradation in stack performance. The degradation rate decreases with time and is relatively low for the last 200 hours of the test. However, from the 118-hour mark to the end of the test, the ASR increased more than $40 \%$ over approximately 900 hours. Reduction of this performance degradation is an objective of ongoing research. Figure 14 shows the corresponding generation of hydrogen.

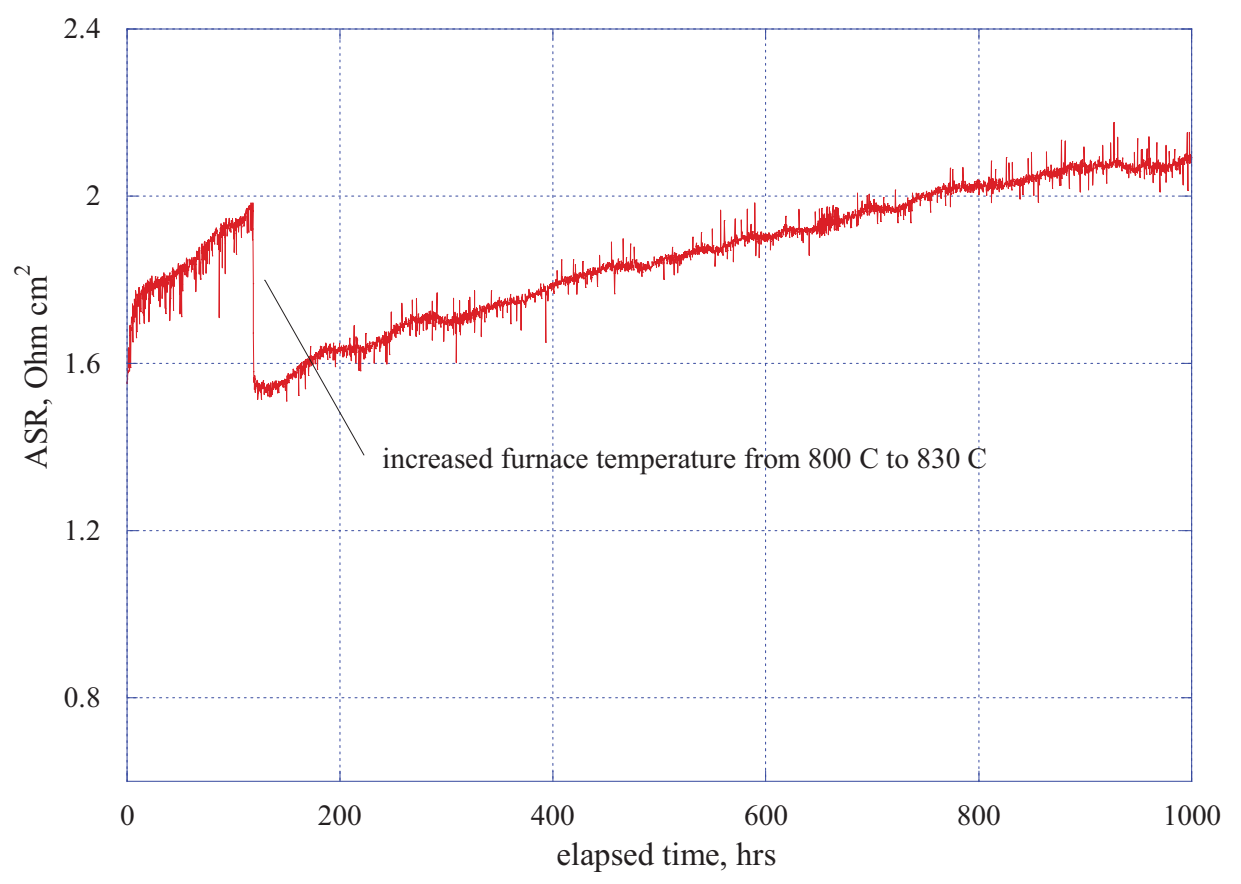

Figure 13. Area-specific resistance of a 25 -cell stack as a function of time for a 1,000-hour test. 


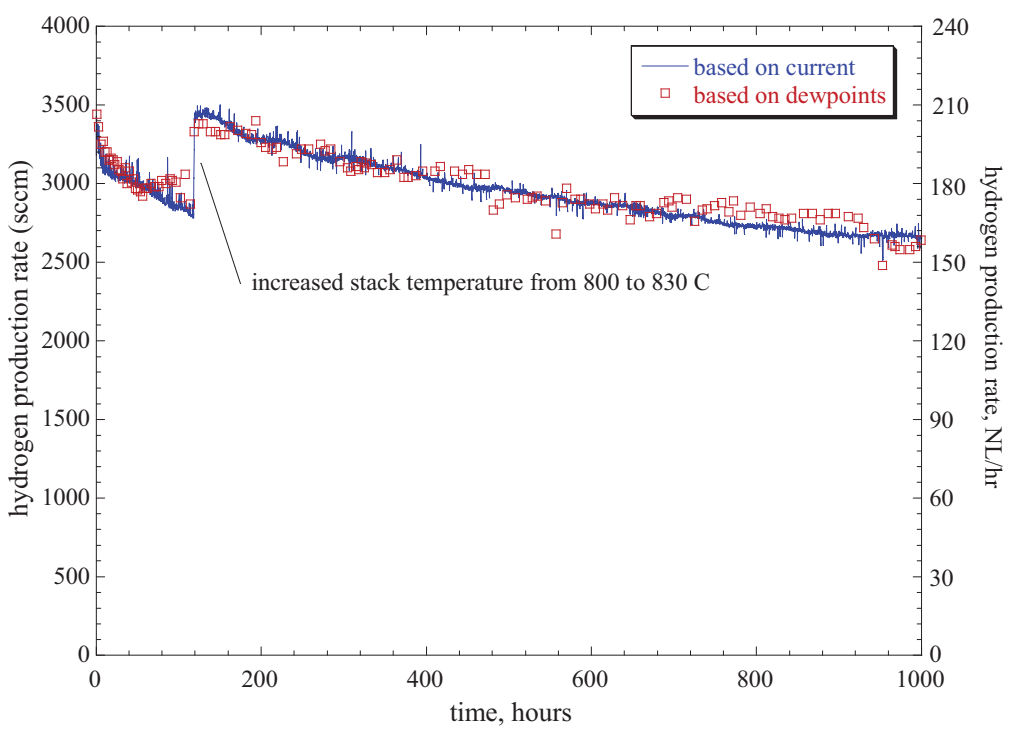

Figure 14. Hydrogen production rates during 1,000-hour long-term test.

Performance degradation of the ILS system is documented in Figure 15. Over a test period of 700 hours, module-average ASR value increased by about a factor of 5, from an initial value near $1.5 \mathrm{Ohm}-\mathrm{cm}^{2}$. Some of the observed degradation was caused by balance-of-plant issues. For example, prior to about 480 hours of testing, unanticipated condensation occurred in the hydrogen recycle system. It led to erratic control of the hydrogen flow rate due to the intermittent presence of liquid water in the mass flow controllers. This problem led to time periods during which there may have been no hydrogen flow to the ILS stacks, leading to accelerated performance degradation associated with oxidation of the nickel cermet electrodes. A plot of the time history of ILS hydrogen production is given in Figure 16. Peak electrolysis power consumption and hydrogen production rate were $18 \mathrm{~kW}$ and $5.7 \mathrm{Nm}^{3} / \mathrm{hr}$, respectively, achieved at about 17 hours of elapsed test time.

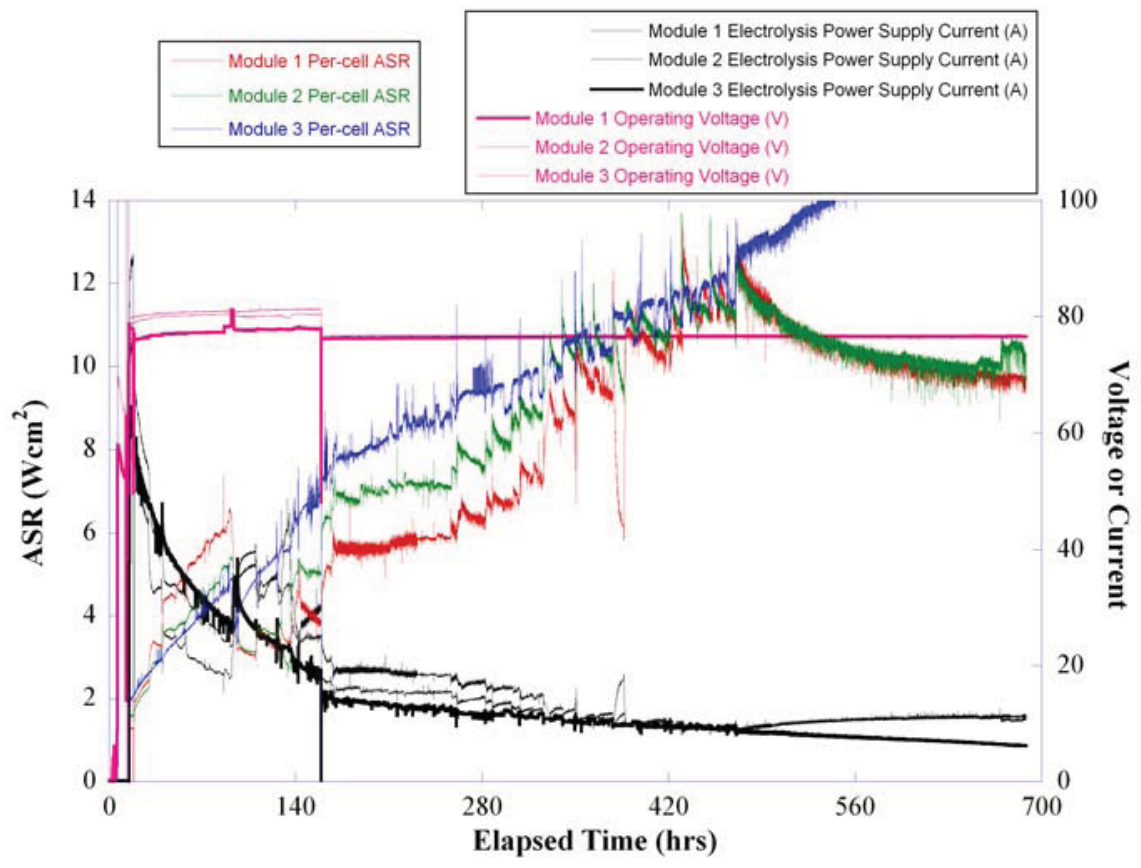

Figure 15. Time history of ILS module ASR values, voltages, and current over 700 hours of operation. 


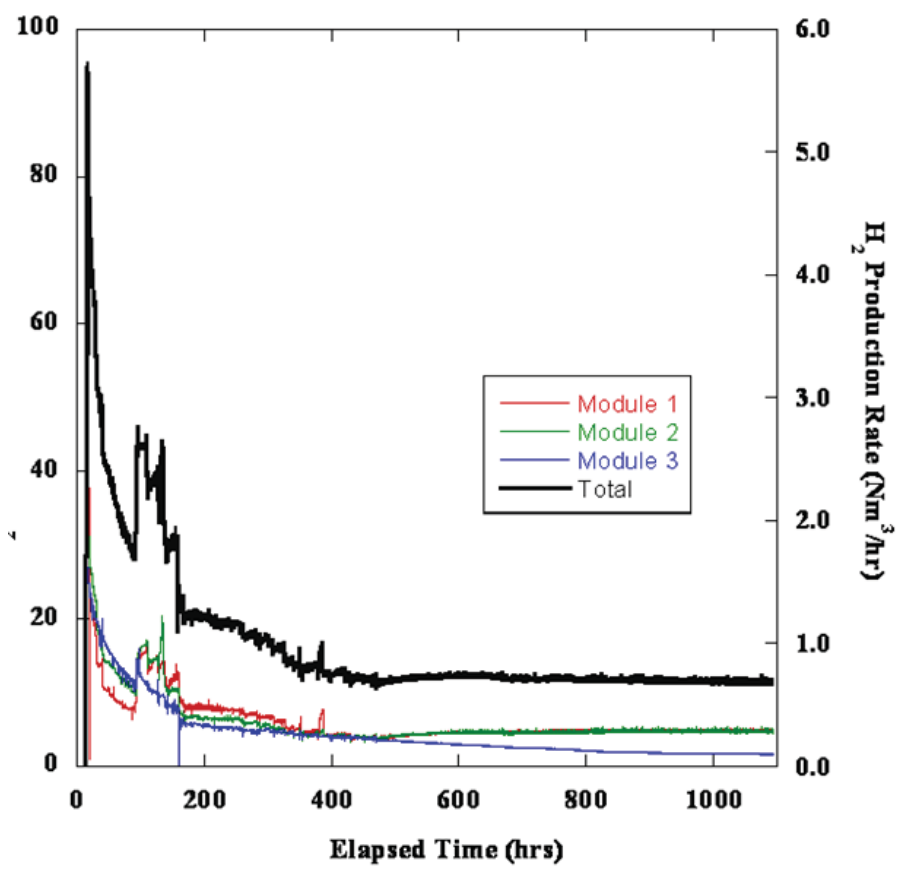

Figure 16. Time history of hydrogen production rate in the ILS.

Mawsdley et al. [2007] presented results of post-test evaluation of the Ceramatec SOECs after a 1,000 -hour test at $\sim 830^{\circ} \mathrm{C}$ [O'Brien et al. 2007). The cells were examined using four-point resistivity measurements, X-ray fluorescence, and Raman spectroscopy. The surface characteristics of cells and bipolar plates were examined for potential causes of long-term degradation. The X-ray fluorescence measurements revealed that during the test, $\mathrm{Mn}$ and $\mathrm{Co}$ from the oxygen electrode and bond layer showed no macroscale interdiffusion. On the other hand, $\mathrm{Cr}$ had diffused from the ferritic stainless steel bipolar plate toward the electrode-electrolyte interface, preferentially through the active electrode area. Raman spectroscopy identified a monoclinic phase in the exposed regions of the zirconia plate near the edge of the plates, which gives evidence of instability of the zirconia cubic phase. Also, Cr-doped $\mathrm{Al}_{2} \mathrm{O}_{3}$ was identified in areas near the seal. SEM images showed delamination and cracking on the edges of the electrodes, where most of the cell degradation occurred. For example, the image in Figure 17 shows that the $\mathrm{O}_{2}$-electrode had begun to delaminate from the electrolyte near the edge where the four-point measurements had shown a large increase in resistivity. Cracks can also be seen within the $\mathrm{O}_{2}$-electrode, which would increase resistivity. Towards the center of the cell (right), adherence to the electrolyte improves and the cracks begin to disappear. If this delamination continues, it would be a source of cell degradation.

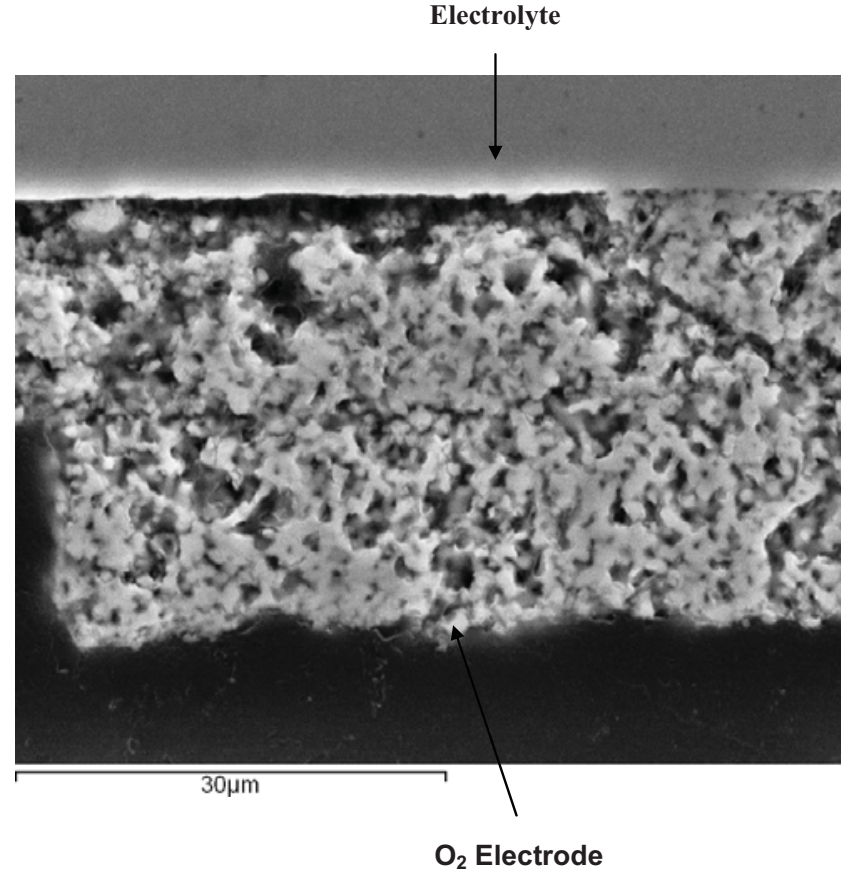

Figure 17. SEM view of the electrolyte and $\mathrm{O}_{2-}$ electrode [Mawdsley et al. 2007]. 


\section{A WORKSHOP ON SOLID OXIDE CELL DEGRADATION}

To understand various degradation issues and seek the opinions of leading researchers on solid oxide (electrolysis) cells, INL organized a workshop titled "Degradation in Solid Oxide Electrolysis Cells and Strategies for its Mitigation," during the 2008 Fuel Cell Seminar \& Exposition in Phoenix, AZ on October 27, 2008. The workshop was attended by researchers from academia, national laboratories, industry, several DOE representatives, and a few researchers from Japan and Germany. The workshop agenda and list of attendees is provided in Appendix A. All contributors to the workshop are herein being credited for their contribution.

The general opinion of workshop attendees and presenters is summarized in this section. Their individual presentations are not reproduced here, but most of them are available to INL workshop organizers. This workshop summary can be useful in providing a direction for future research related to SOEC degradation and adds to the general solid oxide cell fundamentals and degradation related literature presented in previous sections. Because it summarizes the talks and discussions presented at the workshop, some issues are repeated and others excluded, especially those detailed in previously sections. Topics and issues unrelated to cell degradation are also excluded.

\subsection{Understanding Solid Oxide Cell Operation as an Electrolyzer}

Along with INL/Ceramatec's SOEC experience, several researchers around the world have operated solid oxide cells and stacks to generate hydrogen, including Versa Power, MSRI (Salt Lake City, UT), and Risø National Laboratory, Denmark. Their operating experiences have been varied because of the differences in the cell/stack characteristics, but for most, the degradation in SOECs is not identical to that in SOFCs. In order to understand the degradation behavior, material composition, microstructure, and microchemistry of both, the cell's electrodes, electrolyte, and interconnects must be known prior to performing the experiments. This is essential in understanding cell degradation when post-test examinations are performed on a cell. However, some cell manufacturers are unlikely to disclose proprietary information about their patented composition and fabrication technique, which may slow down the progress of SOEC degradation research..

\subsection{Degradation Testing of SOECs by INL and Ceramatec}

\subsubsection{INL}

INL performed several tests aimed at testing the longevity of solid oxide cells in electrolysis mode. Most of the results are given in Section 4.4 and Figures 12-16 above.

\subsubsection{Ceramatec}

Ceramatec has independently tested SOEC and SOFC stacks. Their experience also shows significant differences between electrolysis (SOEC) and fuel cell (SOFC) modes of operation. In a SOEC, mean oxygen partial pressure $\left(\mathrm{p}_{\mathrm{O} 2}\right)$ is higher than that in a SOFC, which may cause severe conditions for corrosion. In SOEC, especially in a single cell, the stack temperature is more uniform, thus reducing potential for thermal stresses. Recently, Ceramatec changed the electrolyte material from YSZ to ScSZ. At the same time, a test of a $1 / 2$-module (120 SOECs) showed 50\% degradation during a 2,000 hour period. Part of this degradation was caused by components other than the SOEC itself, for example: the metal manifold showed corrosion and scaling; the oxygen electrode showed delamination in long duration tests but not in shorter tests; the electrolyte did not show any cracking; and the metal interconnect (edge rail) showed corrosion only in SOEC, which also got eliminated after coating the edge rail and removing silica from the glass seals. 


\subsection{Post-Mortem of INL/Ceramatec SOEC by Argonne National Laboratory and the Massachusetts Institute of Technology}

Some cells were examined by Argonne National Laboratory (ANL); published results from that examination are also given in Section 4.4 and Figure 17 [Mawdsley et al., 2007]. In an effort to understand degradation in Ceramatec SOEC and its distinction from degradation in SOFC, post-mortem of the electrolysis cells was performed at ANL and Massachusetts Institute of Technology (MIT); Carter et al. 2008). The outcome of these investigations reinforced the need for a comprehensive investigation of the degradation phenomena to advance SOEC technology. ANL employed Raman micro-spectroscopy to identify the formation of secondary phases at the electrolyte-bond layer interface. SEM and energy dispersive X-ray spectroscopy (EDX) was also employed to identify the microstructural and compositional distribution at a microscale. They determined that $\mathrm{Cr}$ movement (contamination) in SOEC is different than in SOFC. In the SOEC, because oxygen flows away from $\mathrm{O}_{2}$-electrode-electrolyte interface (see Figures 4, 5, and 7), chromium uniformly diffuses into the cell as seen in the left side of Figure 18. In SOFC, the direction of oxygen flow is reversed and chromium diffuses discretely in various regions of the cell as shown in the right side of Figure 18. However, the severity of chromium contamination is not well understood because of conflicting opinions about it.

At the inlet of $\mathrm{O}_{2}$-electrode, ANL found delamination of electrode from the electrolyte as determined by X-ray fluorescence mapping and SEM imaging. One possible reason of this delamination is excessive pressure build-up with high $\mathrm{O}_{2}$ flow in over-sintered (larger grain size and smaller pores formed at higher temperature) region. Delamination between $\mathrm{O}_{2}$-electrode and electrolyte is shown in Figure 19 [Carter et al. 2008].

Steam at the steam $/ \mathrm{H}_{2}$-electrode inlet can also carry $\mathrm{Si}$ from the seal and deposit it on the $\mathrm{H}_{2}$-electrode as shown in Figure 20 [Carter et al. 2008]. $\mathrm{SiO}_{\mathrm{x}}$ can also come from interconnects, but the bond layer on the $\mathrm{H}_{2}$-electrode does not show the same kind of degradation/delamination as is seen on $\mathrm{O}_{2}$-electrode in Figure 19. Evidence of $\mathrm{Mn}, \mathrm{Si}$, and Ti deposition on the interconnect surface and interconnect-passivation layer interface was also found.

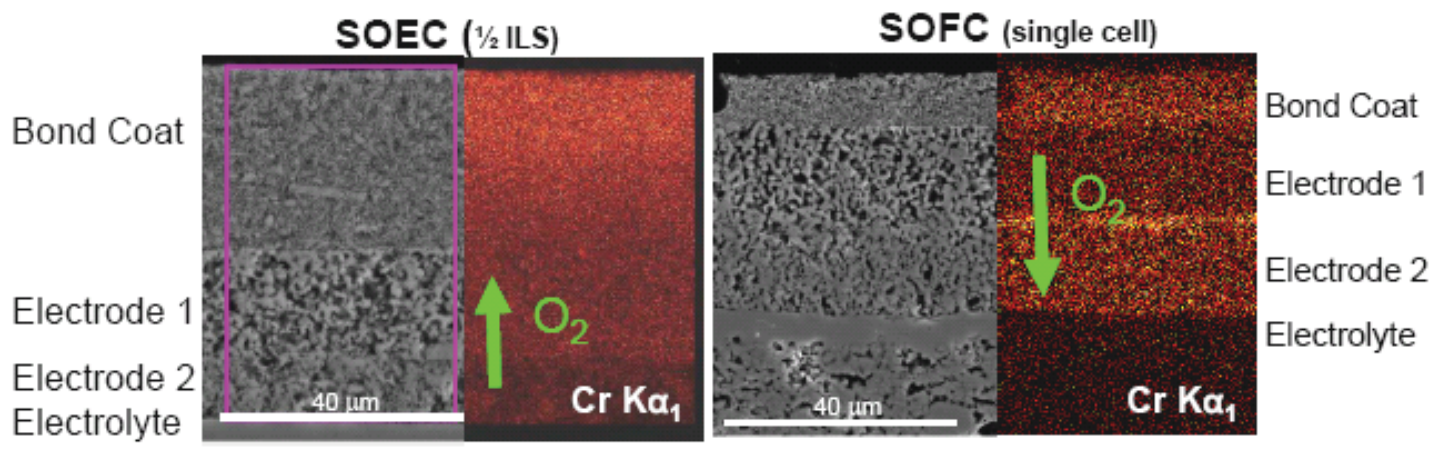

Figure 18. Chromium deposition in SOEC and SOFC [Carter et al. 2008] 


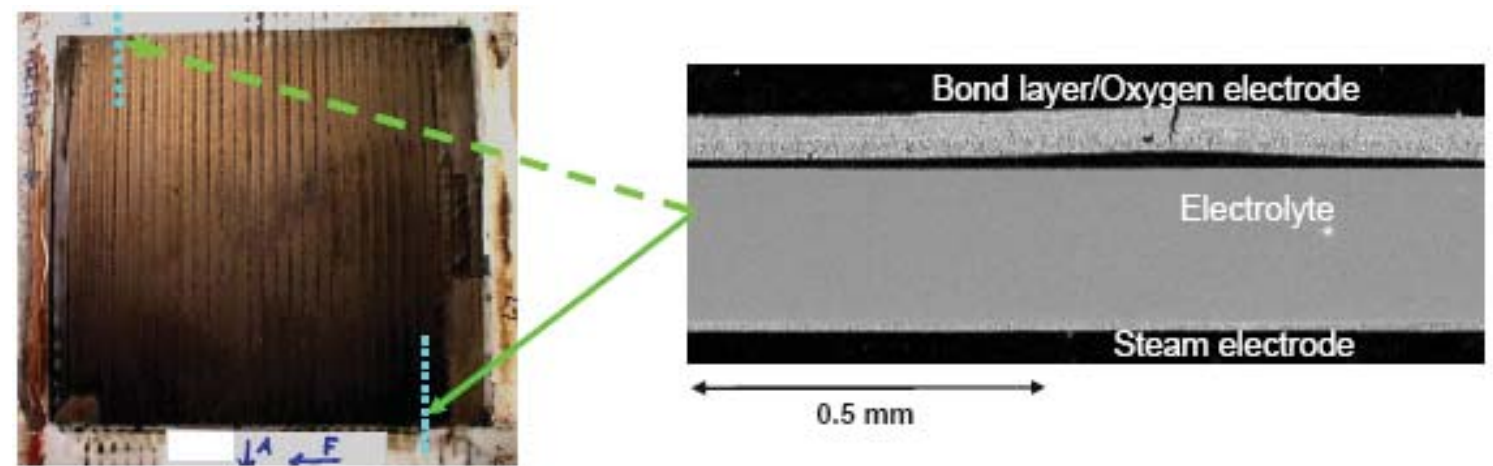

Figure 19. Electrode delamination after $1500 \mathrm{hr}$ of operation [Carter et al. 2008].
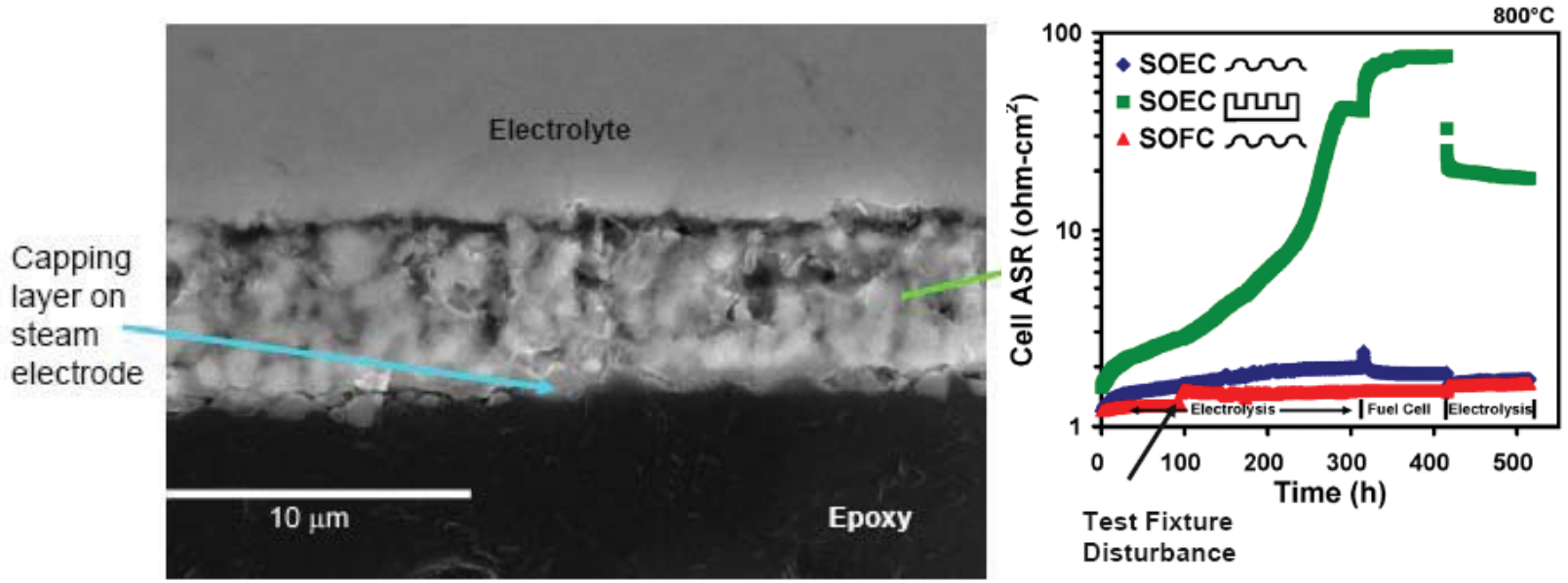

Figure 21. Some reversal of SOEC

Figure 20. Si capping layer on $\mathrm{H}_{2}$-electrode [Carter et al. 2008].

degradation [Carter et al., 2008].

Argonne National Laboratory tested certain cells in both electrolysis and fuel cell (reversible) mode [Carter et al. 2008]. As shown in Figure 21, a cell was operated in electrolysis mode for $\sim 310$ hours. It was then reversed to be operated in fuel cell mode for $\sim 100$ hours, and finally operated again in the electrolysis mode for $\sim 100$ hours. Two SOEC cells were tested. The only difference between the two cells was in the shape of the flow channels (corrugated and square). As shown in Figure 21, reversing the mode of operation provides improves cell performance. A similar cell operated in the fuel cell mode showed stable or even some improvement in performance. The flow channels do not show any signs of degradation. In all the investigations, it was noted that that bond layer on the $\mathrm{O}_{2}$-electrode degraded.

\subsection{Versa Power Systems}

Versa Power Systems has developed and tested solid oxide based cell stacks that can be operated reversibly, in fuel cell and electrolysis modes. The standard cells from Versa Power Systems are anode supported with a surface area of $25 \times 25 \mathrm{~cm}^{2}$ (maximum area being $33 \times 33 \mathrm{~cm}^{2}$ ). The current baseline stack developed under the DOE-SECA project is a $10 \mathrm{~kW}$ SOFC stack with 64 cells. The interconnects are made from ferritic stainless steel. The seals are made from compressible ceramic gasket material. The 
manifolds are integrated into the interconnects, but are not through the cells. Three baseline $10 \mathrm{~kW}$ stacks were tested over 5,000 hours in the past 10 months with a degradation rate of $2-4 \%$ per 1000 hours.

In the past few years, Versa Power Systems has tested a number of cell stacks for solid oxde fuel cell/electrolysis dual-mode operation in the temperature range of 650 to $800^{\circ} \mathrm{C}$. Baseline single cell stacks have run for more than 1600 hours of combined, SOFC/SOEC operations, with 19 cycles between SOFC and SOEC modes. The cell degradation in reversible SOFC/SOEC operation was significantly higher (210 times higher) than that during SOFC operation. In these tests, interconnect degradation is small $(<10 \%)$ in comparison with other cell components $(>90 \%)$. Internal development activities were carried out to boost the SOEC performance and durability at Versa Power Systems. Performance and endurance enhancements were obtained with new, improved cell designs and fabrications. Most recently, several endurance tests have operated more than 1,000 hours in SOEC mode using a second generation of improved cells, and these have demonstrated a $\sim 10$ times improvement in degradation rates from the baseline SOFC/SOEC tests.

\subsection{Forschungszentrum Jülich (FZJ) SOFC Degradation Studies}

Steinberger-Wilckens [2008] of Forschungszentrum Jülich (FZJ) presented some results from Europe's Real-SOFC project, which is aimed at understanding degradation of SOFC, making improvements to reduce degradation, and increasing lifetime of stacks to $>10,000$ hours. So far, the project has achieved $>2.5$ years of life for single planar cells and $\sim 2$ years of life for a planar cell stack.

During the project, FZJ developed two generations of SOFCs (G2 and G3, G1 being the state-of-theart at project initiation). The standard anode substrate type stacks (G1) were made with cells with LSM cathodes and CroFer22APU steel interconnects. The second generation stacks (G2) were fabricated with Plansee ITM steel interconnects. The third generation stacks (G3) were made with LSCF cathodes, adapted cathode contacts and both ITM steel. A variant of the G3 cells (G3-TK) was fabricated using the CroFer22APU steel.

Two G3 short stacks were tested for $>3,000$ hours at $700^{\circ} \mathrm{C}$ and the ASR was determined to be $\sim 0.26 \Omega \cdot \mathrm{cm}^{2}$. Figure 22 shows the long-term performance of the two $\mathrm{G} 3$ stacks being operated with $\mathrm{H}_{2}$ at $700^{\circ} \mathrm{C}, 0.5 \mathrm{~A} / \mathrm{cm}^{2}$, and a fuel $\left(\mathrm{H}_{2}\right)$ utilization of $40 \%$. The drop in performance at about 700 hours and 7,400 hours for G3-TK was caused by failures of certain instruments. During the first 3,000 hours of operation, a degradation rate of $22 \mathrm{~m} \Omega \cdot \mathrm{cm}^{2} / \mathrm{kh}$ was determined for both cells in the G3 stack. After the drop in performance at 700 hours, both cells in G3-TK stack showed similar degradation rates.

Both stacks (G3 and G3-TK) show nearly linear cell voltage drop over the full duration of the tests. This differs from the G1 (LSM cathode) cells, which showed a significant drop in performance in the first 300-500 hours of operation. The improved performance is due to a combination of the lower operating temperature, the LSCF cathode material, and the modified cathode contact layer. Both stacks have completed 15000 hours of operation in mid-May 2009, still showing the gradual, linear degradation at a rate of approx. $6 \mathrm{mV} / 1000$ hours or $0,75 \%$ voltage loss/ 1000 hours.

Figure 23 shows comparison of three identical stacks operated at different temperatures and current densities. The data in Figure 25 show that the operating temperature has more influence on the degradation rate than the current density. However, only detailed post-test examination and analysis may indicate actual reasons for differing degradation rates. 

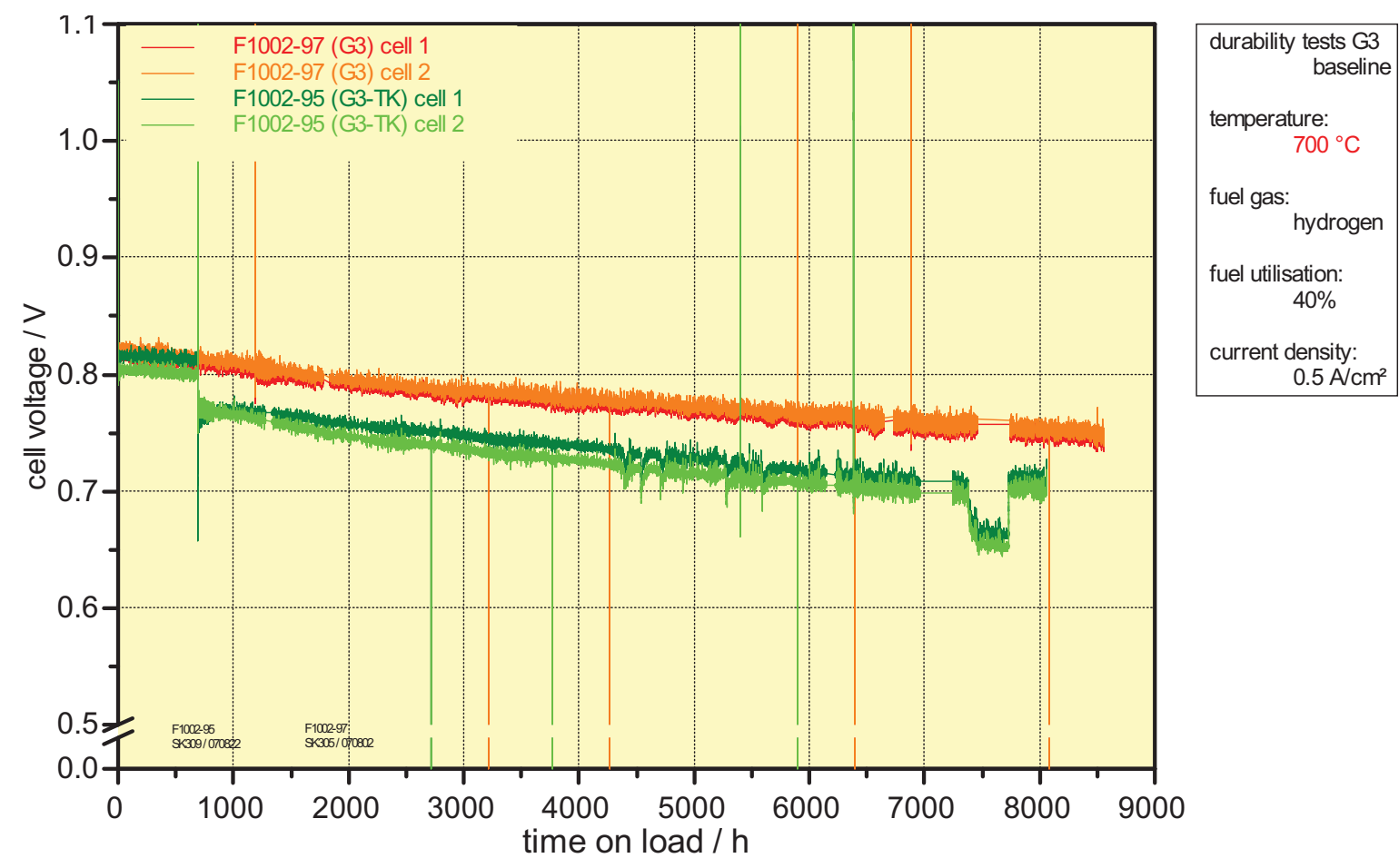

Figure 22. Long-term performance tests on the G3 and G3-TK SOFC stacks operated at $700^{\circ} \mathrm{C}$ with $\mathrm{H}_{2}$ and current density of $0.5 \mathrm{~A} / \mathrm{cm}^{2}$.
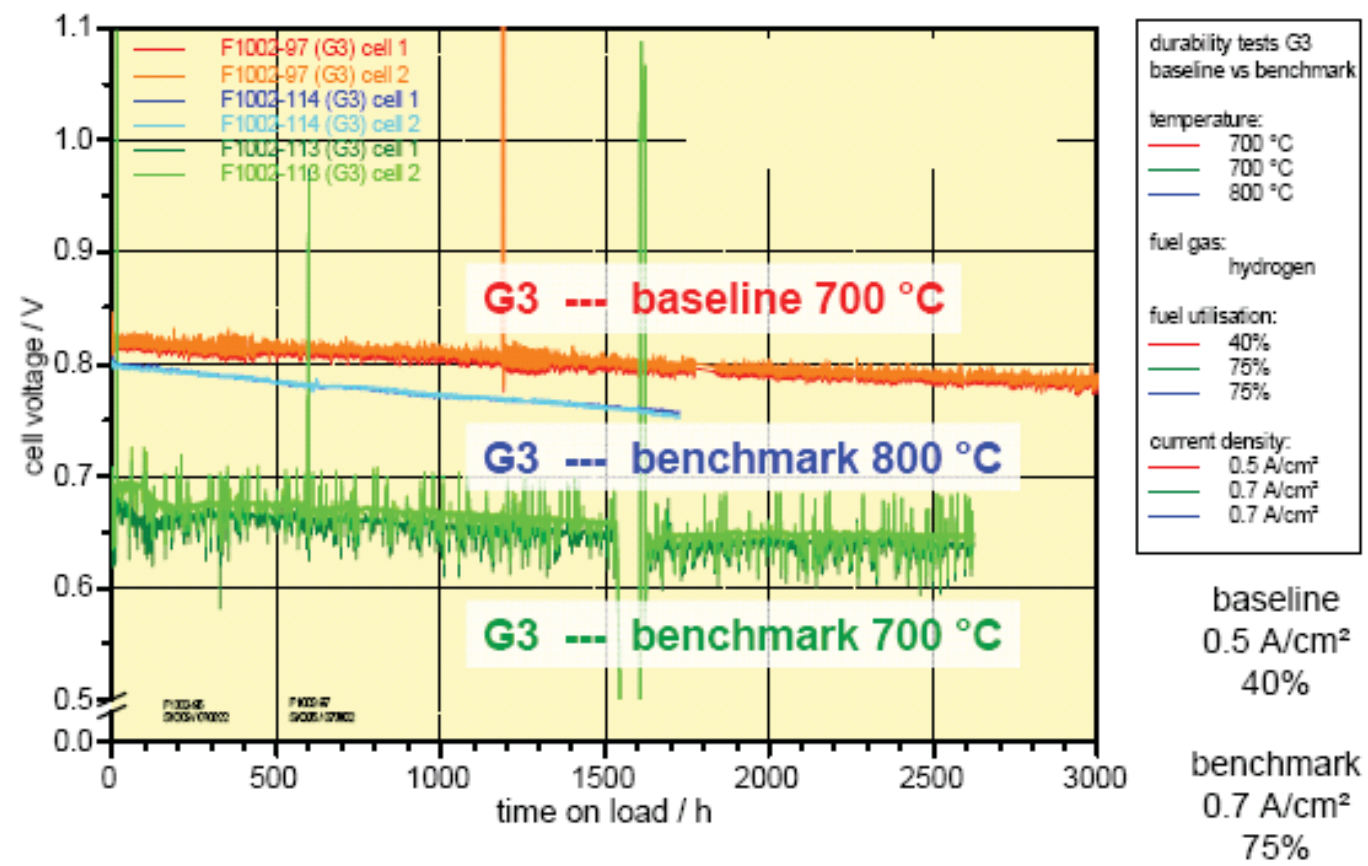

Figure 23. Cell voltage of G3 stacks: the top curve is for $\mathrm{G} 3$ stack operated at $700^{\circ} \mathrm{C}$; the middle curve is for the identical $\mathrm{G} 3$ stack run at $0.7 \mathrm{~A} / \mathrm{cm}^{2}$ and $800^{\circ} \mathrm{C}$; and the bottom curve is for a $\mathrm{G} 3$ stack run at $0.7 \mathrm{~A} / \mathrm{cm}^{2}$ and $700^{\circ} \mathrm{C}$. The latter two were operated at $70 \%$ fuel utilization. 
Figure 23 shows comparison of three identical stacks operated at different temperatures and current densities. The data in Figure 25 show that the operating temperature has more influence on the degradation rate than the current density. However, only detailed post-test examination and analysis may indicate actual reasons for differing degradation rates.

It was also determined that the SOFC degradation is caused by the diffusive gas leakage through compressive seals between the air and fuel compartments. The gas leakage was determined by the posttest inspection, which showed proof of oxygen access. Therefore, seal material and flow-field design were modified to minimize this problem. 


\section{POSSIBLE CAUSES OF DEGRADATION IN SOEC}

At present, a complete understanding and reasonable agreement on the causes of degradation and electrochemical mechanisms behind them does not exist. Therefore, following write-up only represents collective opinion of workshop attendees. It is not inclusive of all the available literature and all the phenomena relevant to degradation by any means.

This information adds to degradation related fundamentals and literature reviews presented in Sections 4 and 5. Experimental data presented in Sections 4 and 5 can be classified as (a) baseline progressive constant-rate degradation, (b) degradation corresponding to transients caused by thermal or redox (reduction and oxidation) cycling phenomena occurring in a cell, and (c) degradation resulting from a sudden incident or a failure/malfunction of a component or a control in a stack system. However, there is no clear evidence if different events lead to similar or drastically different electrochemical degradation mechanisms within a cell.

\subsection{SOEC versus SOFC Stacks}

Sections 4 and 5 present research information on various scenarios of degradation in SOECs and SOFCs; data were taken in single cells as well as in stacks. The degradation mechanisms in a stack are not identical to that in a single cell [Virkar 2007]. Also, degradation in a SOEC is not identical to that in a SOFC. Long-term, single-cell tests show that SOEC operation has greater degradation rates than that in SOFC mode. SOFC degradation can therefore be used for background information and guidance. But for SOEC stack development, all studies have to be done on SOEC stacks. Some researchers observed that higher operating temperature increases degradation in SOEC, but higher current density does not increase degradation. However, ANL observed higher degradation in higher current flow regions of $\mathrm{O}_{2}$-electrodes. Future research needs to resolve such unconfirmed and conflicting opinions.

\subsection{Air/Oxygen Electrode}

It is understood that degradation of the $\mathrm{O}_{2}$-electrode is more severe than that of the $\mathrm{H}_{2}$-electrode. Therefore, it was proposed to focus initially on the degradation of the $\mathrm{O}_{2}$-electrodes in a stack. ANL's examination of a SOEC operated by INL for $\sim 1,500$ hours showed that $\mathrm{O}_{2}$-electrode delaminated from the bond layer/electrolyte. However, the causes of the delamination can be termed as speculative because confirmative tests proving the fundamental cause(s) have not been performed. It is thought that high oxygen evolution in over-sintered region can build up high pressure at that location. In SOEC mode, $\mathrm{O}_{2}$ has to be pushed out, hence chances of delamination increase. Therefore, the high porosity of $\mathrm{O}_{2^{-}}$ electrode is very important. This opinion was expressed by many participants and hence deserves further examination. Per ANL observations, the delamination occurs in cell areas with high current flows. It was also suggested that chromium poisoning originating from the interconnects or the balance-of-plant pipes may get located at the interface or TPB. This can result in bond layer getting separated from the $\mathrm{O}_{2-}$ electrode. Deposition of impurities at the TPB and delamination can adversely impact the electrochemical reactions and ionic conductivity in the cell. It was also mentioned that at the electrode-electrolyte interface, forced electron transfer can form defects. No detailed discussion on the specifics of the phenomenon took place.

\subsection{Air $/ \mathrm{O}_{2}$-Electrode Side Bond Layer}

An $\mathrm{O}_{2}$-electrode side protective bond layer is shown in Figure 5. Because, it is next to the $\mathrm{O}_{2^{-}}$ electrode, it encounters similar electrochemical phenomena that lead to cell degradation. General Electric's work, as shown in Figure 10, also makes reference to bond layer. However, besides ANL's observations, at the workshop, no other studies or data were presented that can demonstrate the bond 
layer's significance relative to the $\mathrm{O}_{2}$-electrode in terms of overall cell degradation. ANL found an average of $1-8 \%(\sim 30 \%$ maximum $)$ Cr-contamination in bond layer, probably originating from interconnects. Cr contaminants were found in association with lanthanum strontium chromite (LSC). In $\mathrm{O}_{2}$ bond layer, a secondary phase may form. However, there are conflicting opinions about severity of $\mathrm{Cr}$ contamination. ANL observed delamination and weak interface between the $\mathrm{O}_{2}$-electrode and LSC bond layer, which can prevent solid state $\mathrm{Cr}$ from diffusing into the $\mathrm{O}_{2}$-electrode. For this reason, the $\mathrm{O}_{2-}$ electrode can remain stable, but a weak interface is not desirable from an electrical conductivity point of view.

\subsection{Electrolyte}

In electrolytes, the main cause of degradation is loss of electrical/ionic conductivity. Müller et al. [2003] showed that during first 1,000 hours of testing, yttria and scandia doped zirconia $\left(8 \mathrm{~mol} \% \mathrm{Y}_{2} \mathrm{O}_{3}\right.$ $\mathrm{Sc}-\mathrm{ZrO}_{2} / 8 \mathrm{YSZ}$ ) electrolytes showed $\sim 23 \%$ of degradation. For the next 1,700 hours of testing, the decrease in conductivity was as high as $38 \%$. An increase in tetragonal phase during annealing at the expense of cubic and monoclinic phases was detected for the 3 YSZ samples. However, 3 YSZ and 4YSZ samples showed much smaller decrease in conductivity after 2,000 hours of testing. Both SteinbergerWilckens [2008] and Hauch [2007a] reported the formation of impurities at the TPBs. A substantial amount of $\mathrm{SiO}_{2}$ was detected at the $\mathrm{Ni} / \mathrm{YSZ} \mathrm{H}_{2}$-electrode-electrolyte interface during electrolysis, while no Si was detected in other reference cells. These Si containing impurities were probably from albite glass sealing. ANL observed that cubic, tetragonal, and monoclinic phases of $\mathrm{ZrO}_{2}$ remained stable at the present Scandia doping level.

\subsection{Steam $/ \mathrm{H}_{2}$-Electrode}

Overall, many researchers reported that the contribution of a steam $/ \mathrm{H}_{2}$-electrode to SOEC degradation is much less than that of other cell components. ANL also observed $\mathrm{Si}$ as a capping layer on steam $/ \mathrm{H}_{2}-$ electrode. It probably was carried by steam from the seals, which contain $\mathrm{Si} \mathrm{SiO}_{\mathrm{x}}$ also emanates from interconnect plates. Mn also diffuses from interconnects, but the significance of Mn diffusion is unknown. Hauch [2007a] observed contaminants containing Si to segregate to the innermost few microns of the H2electrode near the electrolyte. The impurities that diffused to and accumulated at the TPBs of the $\mathrm{H}_{2}$ electrode are believed to be the main cause of performance degradation in SOECs [Hauch 2007a]. In literature, it has been noted that steam content greater than $30 \%$ shows conductivity loss. Therefore, an optimum ratio of steam- $\mathrm{H}_{2}$ mixture and steam utilization percentage needs to be determined.

\subsection{Interconnect}

Interconnects can be a source of serious degradation. $\mathrm{Sr}$, Ti, and Si segregate and build-up at interfaces. Sr segregates to the interconnect-bond layer interface. Mn segregates to the interconnect surface. Si and Ti segregate to the interconnect-passivation layer interface. $\mathrm{Cr}$ contamination can originate from interconnects and it can interact with $\mathrm{O}_{2}$-electrode surface or even diffuse into the $\mathrm{O}_{2}$-electrode. Chromium reduction $\left(\mathrm{Cr}^{6+}\right.$ to $\left.\mathrm{Cr}^{3+}\right)$ can take place at electrode-electrolyte interface [Singh et al. 2008]. Coatings for the interconnects are being developed under the sponsorship of Solid State Energy Conversion Alliance (US-DOE SECA) program. Coated stainless steel interconnects have shown reduced degradation rates. GE observed higher degradation with stainless steel current collectors than with $\mathrm{Au}$ current collectors [Gaun et al. 2006].

\subsection{Contaminants and Impurities}

A hydrogen electrolysis plant or a laboratory-scale experiment is always connected to the pipes, gas storage tanks/cylinders, or other such equipment. These components can be a source of undesirable 
particles/chemicals, which can get deposited at different locations in a solid oxide electrolysis cells. It has been shown in previous sections that any foreign particles depositing at the triple phase boundary can lead to degradation in cell performance. The reactant gases can also have some undesirable impurities. It is understood that the balance of plant and gases are merely sources of impurities. The phenomenological causes of degradation depend on other electrochemical reasons.

Severe corrosion was encountered when glass seals were used, but appeared to be reasonably under control when the glass seals were replaced. Nickel from nickel mesh can volatize in high water content environments, move into the steel and make it austenitic, which will eventually corrode. Silica poisoning is a potential problem. Impure water can contain Si. Therefore, in SOEC, it is likely that high temperature steam interacting with balance-of-plant piping picks up Si and transports it elsewhere to form nonconductive scale. One solution to this problem can be to add certain materials into YSZ electrolyte, which may attract the $\mathrm{Si}$ and reduce degradation. Iron can also diffuse into glass seals and cause electrical shorting. Mn diffuses from interconnect, but its effect on degradation is unknown. Phosphorus and arsenic can react at the PPB levels and interact with the electrode containing Ni. They can form eutectics and enhance Ni mobility. This is a very low-level effect and demands appropriate detection techniques.

\subsection{Summary of Stack Degradation}

Main sources of degradation come from several cell components. Details about the following list of general observations and main sources of SOEC stack degradation have been discussed in earlier sections:

- Delamination of $\mathrm{O}_{2}$-electrode side bond layer from the $\mathrm{O}_{2}$-electrode,

- Bond layer on steam $/ \mathrm{H}_{2}$-electrode side is not degrading,

- Air and steam $/ \mathrm{H}_{2}$ flow fields (flow channels) are not degrading,

- Five cell components are suspect:

- Bond layer on $\mathrm{O}_{2}$-electrode-Cr poisoning and dissociation

- $\mathrm{O}_{2}$-electrode-microstructural changes and delamination

- Loss of electrical/ionic conductivity of electrolyte

- Interconnect-generation of contaminants

- Steam $/ \mathrm{H}_{2}$ - electrode

This list is not all inclusive, but represents a majority opinion expressed at the workshop. Main sources of degradation come from several cell components.

\subsection{Measurements to Quantify Degradation}

There are two common definitions for quantifying degradation given by Gemmen et al. [2008]. Area Specific Resistance (ASR) is defined in Equation (11). The ASR represents instantaneous degradation rate. Another degradation definition is termed as average degradation rate, $D \bar{R}(t)$. It is defined for a time period of $\left(\mathrm{t}-\mathrm{t}_{0}\right)$. Thus for any cell voltage $\mathrm{V}\left(\mathrm{I}_{\mathrm{s}}, \mathrm{t}\right)$, at a time $\mathrm{t}$, average degradation rate, $D \bar{R}(t)$, is given by [Gemmen et al. 2008]:

$D \bar{R}(t)=\frac{V\left(i_{s}, t_{0}\right)-V\left(i_{s}, t\right)}{V\left(i_{s}, t_{0}\right) \times\left(t-t_{0}\right)} 100$.

ASR is best suited for comparing the performances of the same cell with two types of technologies such as one type of interconnect design with another. However, DR is more suitable for comparing cell 
performance with a stack performance of the same type of cells. To understand the degradation phenomena, a solid oxide electrolyzer needs to be operated and tested. Figures 8-10 show some of the data that were taken during the tests performed at INL. Current density, voltage, area specific resistance (ASR), cell system temperature, reactants, and product flow rates are some of the commonly measured parameters during the tests. However, to understand the electrochemical behavior of the electrodes and electrolytes, their chemical microstructure has to be understood before and after an electrolysis operation. Also, the location of the impurities, for example, $\mathrm{Ni}, \mathrm{Cr}$, and their movement as a result of the electrolysis operation should be identified. The impact of the impurities movement on electrochemical performance of a single cell and a stack should also be determined by making relevant measurements.

\subsection{Measuring and Assessing Impact of Key Parameters}

Generally, the Ni phase provides a high number of TPBs at the electrode-electrolyte interface, which also provides an electronic conduction path. Therefore, at high temperatures, a SEM is commonly used to examine the microstructure of the cell components. Digital images from optical microscopy and SEM images can be used to analyze the location of Ni particles. Specialized filtering techniques can be applied to eliminate noise effects around the profile of the particles, but two-dimensional particle images cannot give the absolute size of the particles, and their interconnection in the three-dimensional space cannot be determined [Thydén 2008]. Thydén [2008] describes a technique for visualizing and characterizing the microstructure of the Ni-YSZ electrode and evaluating the distribution of percolating $\mathrm{Ni}$ and nonpercolating Ni, YSZ, and pores. An appropriate software (for example Amira 4.1), can be used to reconstruct and visualize the images acquired by the SEM. Movement of the impurities from seals and interconnects can also lead to degradation. Various advanced measuring instruments can be employed to measure key stack parameters. Some of the measuring methodologies being, X-ray scattering and spectroscopy, TEM, X-ray photoelectron spectroscopy, high resolution site-specific microscopy, etc. EIS and several other methods/tools are available to obtain detailed information about phenomenological happenings in a solid oxide cell, including: Raman spectroscopy, synchrotron X-ray fluorescence, SEMEDS, nano-probe Auger electron spectroscopy, and FIB-SEM. It would be highly useful to be able to develop innovative ways to correlate structural and chemical composition data to cell electrochemical performance, especially in situ.

Some special experimental techniques may need to be developed to study degradation phenomena, such as intentionally introducing Si into a button cell so it can be analyzed in post-mortem analysis. Other contaminants can be also be analyzed in single phenomenon tests.

Several models can quantify the impact of some key parameters in SOFCs and SOECs. These model can include $\mathrm{O}_{2}$-electrode delamination, interconnect oxidation, $\mathrm{Cr} /$ sulfur poisoning, interconnect detachment (curvature or warpage due to thermal stresses), poisoning of the $\mathrm{H}_{2}$-electrode (can be extrapolated to poisoning of the oxygen side electrode). Time domain diagnostics such as a load switching circuit that would change the load on the cell without too much disruption, could prove useful for assessing large-scale SOEC systems

\subsection{Electrochemical Impedance Spectroscopy}

Electrochemical impedance spectroscopy (EIS) is a well-known technique used to study electrochemical characteristics of systems such as batteries, capacitors, and fuel cells, and widely used in disciplines such as corrosion and materials science. Electrochemical techniques [Gabrielli 1997] can be used whenever a voltage-controlled transfer of electrical charge occurs at the interface between an electrode and an electrolyte. The electrode and electrolyte form a "cell" in which electrochemical response takes place corresponding to the physical/chemical reactions taking place in the cell. Any polarization resistance at the interface induces a response in the form of an electric current. This is the 
basis of electrochemical techniques, where all the quantities that establish the state of the interface (temperature, pressure, area, etc.) are kept constant and the response of one of the electrical quantities (current or potential) is observed, while the other is perturbed. The electrical perturbation provokes an oxidation or a reduction in the cell. The impedance of a cell is measured at different frequencies. The AC response from the cell over a range of applied frequencies is analyzed by the frequency response analyzer and the impedance is calculated [Hauch 2007a]. From the measured EIS results, the ohmic resistance is found as the value of the real part of the impedance measured at the highest frequency. The polarization resistance is the real part of the impedance at the lowest frequency minus the real part of the impedance measured at the highest frequency. AC impedance measurements can be used to study degradation because they change differently for different degradation types. The underlying idea is that individual processes will appear in the impedance spectrum at different frequencies according to their inherent rate. For example, a charge transfer process is more likely to show up at higher frequencies than a slower diffusional process. This technique is convenient because it is minimally invasive and can be used while a system is in operation. Its resolution in frequency allows the separate study of simultaneous cell processes, potentially enabling their individual optimization. A schematic diagram of an EIS system is shown in Figure 24 [Hauch 2007a].

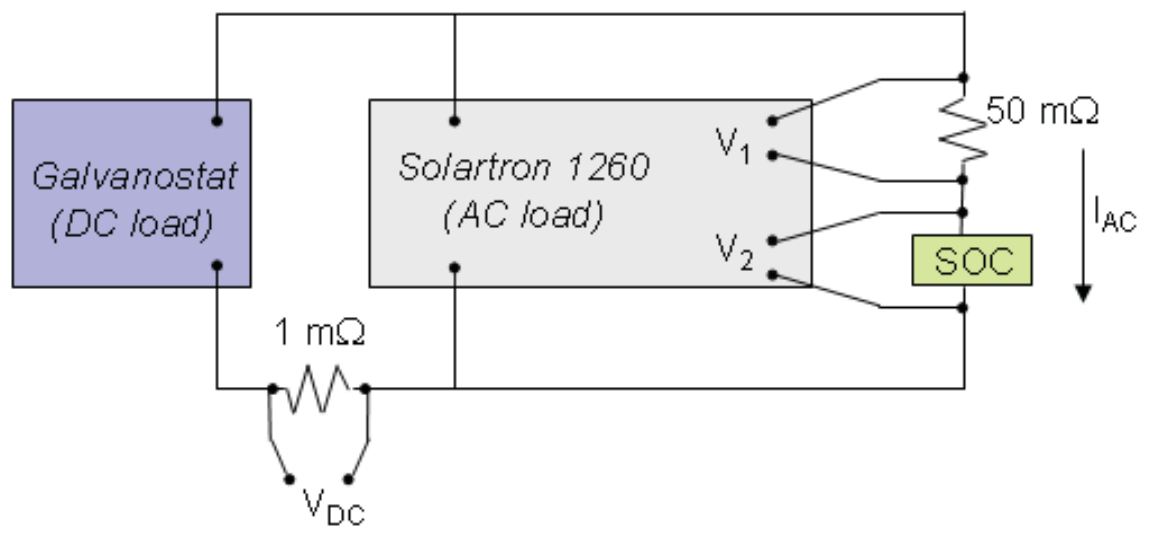

Figure 24. A typical example of EIS measuring setup [Hauch 2007]. 


\section{SUMMARY AND RESEARCH NEEDS TO MITIGATE SOEC DEGRADATION}

The workshop attendees expressed their opinion about research priorities for understanding and resolving degradation in SOEC and SOFC. This section summarizes their collective opinion. Various research topics are not ranked because no attempt was made to do that and the knowledge base on SOEC is quite limited in both academic and industrial sectors.

It may be desirable to establish some SOEC performance targets in terms of current density, tolerable degradation rate, and desired lifetime of the SOEC stacks. Similar to SECA goals, a lifetime of 20,000 hours may be desirable, but a focused research approach has to be conducted to achieve these goals.

\subsection{Electrochemical Phenomena in SOEC Cells and Stacks}

Addressing the problem of degradation in a SOEC stack will require an understanding of all the electrochemical phenomena at a single cell level. The same phenomena should then be scaled up to a stack level. However, it is generally accepted that a single cell's performance cannot predict the performance of a stack made from the same cell. Therefore, the differences between the electrochemical behavior of a single cell and a stack should be clearly identified. Electrochemical similarities and differences between operations of SOEC and SOFC stack operations should also be clearly identified. It is hoped that understanding the electrochemical phenomena during normal operation of a SOEC stack will lead to an understanding of off-normal operation resulting from a degraded stack. Many of the phenomena require the cells to behave in a nonequilibrium thermodynamic manner. This approach is being promoted by Virkar [2007]. Such fundamental understanding can benefit in identifying the causes of degradation and resolving the same.

\subsection{Electrochemical Phenomena in SOEC Stacks and Cell Material Composition}

The electrochemical behavior of a SOEC stack in relation to the material composition of all cell components needs to be understood. Many electrochemical events responsible for normal and off-normal cell operation occur at the interface between various components, for example $\mathrm{O}_{2}$-electrode-bond layer, TPB. Different material compositions of various components impact a cell's electrochemical behavior differently. Thus the relationship between various materials and their corresponding degradation in a SOEC stack needs to be established. If successful, this could lead to cell composition that result in lower degradation rates. This knowledge can be very useful for a SOEC cell manufacturer.

\subsection{Modeling Electrochemical Phenomena and Stack Degradation}

Understanding electrochemical phenomena is essential for developing a model of a SOEC stack. With a suitable model, various stack characteristics and operating parameters, such as, materials of composition, operational transients, thermal cycling, redox cycling, etc., can be modeled to understand the impact of a single or several parameters on stack degradation. It can also help to understand the relative importance of various cell/stack parameters. A functioning model could thus be used to improve the material composition of cell components. As a general rule, any process model is used to plan for experimental testing and improve operation. If the coupling of various electrochemical phenomena are too complex, as a minimum, single phenomenon models should be developed that can also be verified by experimentation 


\subsection{Delamination of $\mathrm{O}_{2}$-Electrode and Bond-Layer}

The delamination of an $\mathrm{O}_{2}$-electrode and its role in causing cell degradation was previously discussed. Workshop attendees agreed that $\mathrm{O}_{2}$-electrode delamination is a major problem that needs to be addressed. Therefore, understanding the causes of $\mathrm{O}_{2}$-electrode delamination and its mitigation should be considered a high priority.

\subsection{Contaminant Transport and Deposition}

Almost everyone actively involved in SOFC research emphasizes that the deposition of contaminants (chromium, nickel, silica, etc.) at reaction sites (for example triple phase boundary) leads to degradation of SOFC performance. However, their relative contribution to degradation in SOEC is not well known. Some groups (for example, Risø National Laboratory, Denmark) strongly believe that even in SOEC, contaminants have significant impact on degradation. Others such as Virkar [2007] believe that other phenomena are the primary causes of cell degradation/failure. The source of these contaminants could be balance-of-plant, interconnects, seals, and external sources. In view of these differing opinions, the source of contaminants and their transport mechanism, poisoning and de-activation of reaction sites, and buildup of scales and layers and their relative impact on degradation should be resolved.

\subsection{Redox Cycling and its Impact on Degradation}

Reduction and oxidation (Redox) cycling is a common issue in $\mathrm{H}_{2}$-electrode (anode in SOFC) supported cells. Redox cycling leads to electrode instability. $\mathrm{H}_{2}$-electrodes must possess a high performance in terms of high electrochemical activity and high redox stability. Ni--YSZ $\mathrm{H}_{2}$-electrodes often above $80^{\circ} \mathrm{C}$ are normally not redox stable. Volume changes in Ni--YSZ electrodes due to reduction and oxidation of $\mathrm{Ni}$ results in mechanical stresses in the electrode material, which degrades cell performance. For SOFCs, researchers are looking for an electrode material (usually ceramic based) that will have a minimal impact on the redox problem. The relative impact of redox on SOEC cell degradation is not well understood.

\subsection{Interconnects and Seals Related Problems}

Chromium evaporation/condensation from interconnects, seal leakage, and the origination of contaminants from interconnects and seals also contribute to the degradation of SOEC performance. Seal leakage, $\mathrm{SiO}_{\mathrm{X}}, \mathrm{Mn}$ poisoning, etc., are considered second order effects. Hence, their relative impact on degradation needs to be quantified and acceptable solutions need to be developed.

\subsection{Other Related Issues}

Several researchers, especially with SOFC experience, have pointed out other issues, some of which have not been examined in the SOEC scenario and hence, may not have the same degree of impact in a SOEC as they do in a SOFC. Corrosion is a common issue and can increase resistivity, change dimensions because of cell component swelling. SOEC electrode material may be required to be improved to improve gaseous transport, improve reaction sites, increase mechanical strength, and improve conductivity. Overall, these improvements should decrease the degradation rate. 


\section{REFERENCES}

Akkaya, A. V. (2007). "Electrochemical Model for Performance Analysis of a Tubular SOFC," Int. J. Energy Research, 31, 79-98.

Appel, C. C., Bonanos, N., Horsewell, A., and Linderoth, S. (2001). “Ageing Behaviour of Zirconia Stabilized by Yttria and Manganese Oxide,” J. Materials Science, 36, 4493-4501.

Blum, L. et al. (2007). "Solid Oxide Fuel Cell Development at Forschungszentrum Juelich," Fuel Cells 7 , $3,204-210$.

Carter, D. J. et al. (2008). "Determining Causes of Degradation in High Temperature Electrolysis Stacks," Presented at the Workshop on Degradation in Solid Oxide Electrolysis Cells and Strategies for its Mitigation, October 27, 2008, Fuel Cell Seminar \& Exposition, Phoenix, AZ.

Gabrielli, C., (1997). "Use and Applications of Electrochemical Impedance Techniques," Solartron Analytical Technical Report 24, www.solartronanalytical.com/downloads/technotes/.

Gazzarri, J. I. (2007). “Impedance Model of a Solid Oxide Fuel Cell for Degradation Diagnosis,” Ph. D. Thesis, The University of British Columbia, Vancouver, Canada.

Gemmen, R. S., Williams, M. C., and Gerdes, K. (2008). "Degradation Measurement and Analysis for Cells and Stacks,” J. Power Sources, 184, 251-259.

Guan, J. et al. (2006). "High Performance Flexible Reversible Solid Oxide Fuel Cell,” GE Global Research Center Final Report for DOE Cooperative Agreement DE-FC36-04GO-14351.

Gubner, A., Landes, H., Metzger, J., Seeg, H., and Stubner, R.(1997). In Proceedings of the 5th International Symposium on Solid Oxide Fuel Cells (SOFC-V), Aachen, Germany, Edited by Stimming, U., Singhal, S. C., Tagawa, H., and Lehnert, W., The Electrochemical Society, Pennington, NJ, 1997, 844-850.

Hagen, A., Barfod, R., Hendriksen, P. V., Liu, Y. L., and Ramousse, S. (2006). "Degradation of Anode Supported SOFCs as a Function of Temperature and Current Load," J. Electrochemical Society, 153(6), 2006, A1165-A1171.

Haering, C., Roosen, A., Schichl, H., and Schnoller, M., (2005). "Degradation of the electrical conductivity in stabilized zirconia system Part II: Scandia-stabilised zirconia," Solid Sate Ionics, 176 (3-4), 261-268.

Hauch, A., Jensen, S. H., Menon, M., and Mogensen, M. (2005). "Stability of Solid Oxide Electrolyser Cells," Risø International Energy Conference, 23-25 May, 2005, Roskilde, Denmark, (Edited by) Petersen, L. S. and Larsen, H.

Hauch, A. (2007a). "Solid Oxide Electrolysis Cells - Performance and Durability," Ph.D. Thesis, Technical University of Denmark, Risø National Laboratory, Roskilde, Denmark.

Hauch, A., Jensen, S. H., Ebbesen, S. D., and Mogensen, M. (2007b). "Durability of Solid Oxide Electrolysis Cells for Hydrogen Production," Risø International Energy Conference, 2007, Roskilde, Denmark, (Edited by) Petersen, L. S. and Larsen, H

Hauch, A., Ebbesen, S. D., Jensen, S. H., and Mogensen, M. (2008). "Solid Oxide Electrolysis Cells: Microstructure and Degradation of the Ni/Yttria-Stabilized Zirconia Electrode," J. Electrochemical Society, 155(11), B1184-B1193.

Heneka, M. J. and Ivers-Tiffée, E. (2005). "Influence of High Current on the Performance of SOFC Single Cells," in Proceedings of the $26^{\text {th }}$ Risø International Symposium on Materials Science: Solid State Electrochemistry, (Edited by) Linderoth, S., et al., Roskilde, Denmark, 215-222. 
Herring, J. S., Stoots, C. M., O'Brien, J. E., Hartvigsen, J. J., and Housley, G. (2007). "Recent Progress in High Temperature Electrolysis,” AIChE Meeting, Salt Lake City, UT, November 5-9, 2007.

Høgh, J. (2005). "Influence of Impurities on the $\mathrm{H}_{2} / \mathrm{H}_{2} \mathrm{O} / \mathrm{Ni} / Y S Z$ Electrode," Ph.D. Thesis, Technical University of Denmark, Risø National Laboratory, Roskilde, Denmark.

Itoh, H. (1995). "Research and Development on High Performance Anode for Solid-Oxide Fuel Cells Improvements of the Microstructure for New Long Life Anode," Central Research Institute of Electric Power Industry (CRIEPI), Japan, Report W94016.

Ivers-Tiffée, E. and Virkar, A. V. (2003). "Electrode Polarisation," Chapter 9 in High Temperature Solid Oxide Fuel Cells: Fundamentals, Design and Applications, (Edited by) Singhal, S. C. and Kendall, K., Elsvier, Oxford, U.K.

Jensen, K. V. (2002). “The Nickel-YSZ Interface,“ Ph.D. Thesis, Technical University of Denmark, Risø National Laboratory, Roskilde, Denmark.

Jørgensen, M. J., Holtappels, P., and Appel, C. C. (2000). "Durability Test of SOFC Cathodes," J. Applied Electrochemistry, 30, 411-418.

Klemensø, T., Chung, C., Larsen, P. H., and Mogensen, M. (2005). "The Mechanism Behind Redox Instability of Anodes in High-Temperature SOFCs," J. Electrochemical Society, 152(11), A2186A2192.

Klemensø, T., and Mogensen, M. (2007). "Ni-YSZ Solid Oxide Fuel Cell Anode Behavior upon Redox Cycling based on Electrical Characterization," J. American Ceramic Society, 90(11), 3582-3588.

Koehler, T. M., Jarrell, D. B., and Bond, L. J. (2001). "High Temperature Ceramic Fuel Cell Measurement and Diagnostics for Application to Solid Oxide Fuel Cell Systems," Pacific Northwest National Laboratory Report No. PNNL-13716.

Liu, Y. L., Primdahl, S., and Mogensen, M. (2003). "Effect of Impurities on Microstructure in Ni/YSZYSZ Half Cells for SOFC," Solid State Ionics, 161, 1-10.

Liu, Y. L. and Jiao, C. G. (2005). "Microstructure Degradation of an Anode/Electrolyte Interface in SOFC Studied by Transmission Electron Microscopy," Solid State Ionics, 176, 435-442.

Mawdsley, et al. (2007). "Post-Test Evaluation of the Oxygen Electrode from a Solid Oxide Electrolysis Stack and Electrode Materials Development," AIChE Meeting, Salt Lake City, UT, November 5-9, 2007.

Mitterdorfer, A. and Gauckler, L. J. (1998). " $\mathrm{La}_{2} \mathrm{Zr}_{2} \mathrm{O}_{7}$ Formation and Oxygen Reduction Kinetics of the $\mathrm{La}_{0.85} \mathrm{Sr}_{0.15} \mathrm{Mn}_{\mathrm{y}} \mathrm{O}_{3}, \mathrm{O}_{2}(\mathrm{~g}) / \mathrm{YSZ}$ System," Solid State Ionics, 111 (3-4), 185-218.

Müller, A.C., Weber, A., Herbstritt, D., and Ivers-Tiffée, E. (2003). "Long Term Stability of Yttria and Scandia doped Zirconia Electrolytes," Proceedings $8^{\text {th }}$ International Symposium on SOFC, (Edited by) Singhal, S. C., Dokiya, M., PV 2003-07, The Electrochemical Society, 196-199.

Ni, M., Leung, M. K. H., and Leung, D. Y. C. (2006). "A Modeling Study on Concentration Overpotentials of a Reversible Solid Oxide Fuel Cell,” J. Power Sources, 163, 460-466.

Noren, D. A. and Hoffman, M. A. (2005). "Clarifying the Butler-Volmer Equation and Related Approximations for Calculating Activation Losses in Solid Oxide Fuel Cell Models," J. Power Sources, 152, 175-181.

O'Brien, J. E., Stoots, C. M., Herring, J. S., and Hartvigsen, J. J. (2007). "Performance of Planar HighTemperature Electrolysis Stacks for Hydrogen Production from Nuclear Energy," Nuclear Technology, 158, 118-131. 
O’Brien, J. E., Stoots, C. M., Herring, J. S., Condie, K. G., and Housley, G. K. (2009). “The HighTemperature Electrolysis Program at the Idaho National Laboratory: Observations on Performance Degradation," High Temperature Water Electrolysis Limiting Factors, Eifer, Karlsruhe, Germany, June 9-10.

Shih, H. and Lo, T.-C. (1996). "Electrochemical Impedance Spectroscopy for Battery Research and Development," Solartron Analytical Technical Report 31, .www.solartronanalytical.com/downloads/technotes/.

Simwonis, D., Tietz, F., and Stöver, D. (2000). "Nickel Coarsening in Annealed Ni/8YSZ Anode Substrates for Solid Oxide Fuel Cells," Solid State Ionics, 132(3-4), 241-251.

Singh, P., Pederson, L. R., Stevenson, J. W., King, D. L., and McVay, G. L. (2008). "Understanding Degradation Processes in Solid Oxide Fuel Cell Systems," Presented at the Workshop on Degradation in Solid Oxide Electrolysis Cells and Strategies for its Mitigation, October 27, 2008, Fuel Cell Seminar \& Exposition, Phoenix, AZ.

Steinberger-Wilckens, R. (2008), "Degradation Issues in SOFCs," Presented at the Workshop on Degradation in Solid Oxide Electrolysis Cells and Strategies for its Mitigation, October 27, 2008, Fuel Cell Seminar \& Exposition, Phoenix, AZ.

Tang, E. (2008). "Solid Oxide Electrolysis Cell Performance at Versa Power Systems," Presented at the Workshop on Degradation in Solid Oxide Electrolysis Cells and Strategies for its Mitigation, October 27, 2008, Fuel Cell Seminar \& Exposition, Phoenix, AZ.

Thydén, K. (2008). "Microstructural Degradation of Ni-YSZ Anodes for Solid Oxide Fuel Cells," Ph.D. Thesis, Risø National Laboratory, Technical University of Denmark, and Niels Bohr Institute, University of Copenhagen, March 2008.

Tu, H. and Stemming, U. (2004). “Advances, Aging Mechanisms, and Lifetime in Solid-Oxide Fuel Cells,” J. Power Sources, 127, 284-293.

Tucker, M. C., Kurokawa, H., Jacobson, C. P., De Jonghe, L. C., and Visco, S. J. (2006). "A Fundamental Study of Chromium Deposition on Solid Oxide Fuel Cell Cathode Materials," J. Power Sources, 160, 130-138.

Virkar, A. V. (2007). “A Model for Solid Oxide Fuel Cell (SOFC) Stack Degradation,” J. Power Sources, 172, 713-724.

Windisch, C.F., Stevenson, J. W., Simner, S. P., Williford, R. E., and Chick, L. A. (2002). "Experimentally-Calibrated Spreadsheet-based SOFC Unit-Cell Performance Model," Pacific Northwest National Laboratory, PNNL-SA-37014, presented at 2002 Fuel Cell Seminar: Fuel CellsReliable, Clean Energy for the World, Palm Springs, CA, 21 November 2002

Yokokawa, H., Sakai, N., Horita, T., Yamaji, K., Brito, M. E., and Kishimoto, H., (2008). "Thermodynamic and Kinetic Considerations on Degradations in Solid Oxide Fuel Cell Cathodes," J. Alloys and Compounds, 452, 41-47.

Zhen, Y. D., Tok, A. I. Y., Jiang, S. P., and Boey, F. Y. C. (2007). "La(Ni, Fe)O ${ }_{3}$ as a Cathode Material with High Tolerance to Chromium Poisoning for Solid Oxide Fuel Cells," J. Power Sources, 170, 61-66. 
Appendix A

\section{Seminar Agenda and Attendee List}




\section{APPENDIX A}
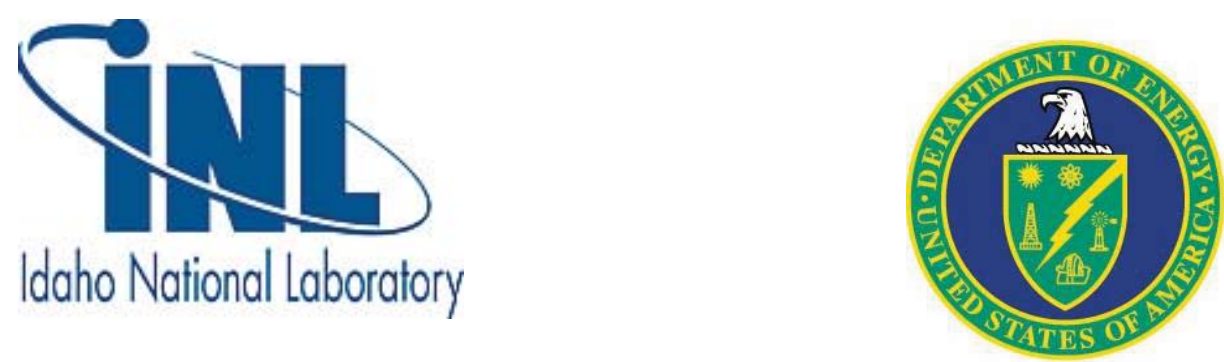

\section{Agenda for}

\section{"Degradation in Solid Oxide Electrolysis Cells and Strategies}

for its Mitigation"

Monday, October 27, 2008, Fuel Cell Seminar \& Exposition 2008

Room 211B, Phoenix Convention Center West Building, Phoenix, Arizona

\begin{tabular}{|c|c|c|}
\hline $8: 00-8: 10$ AM & Welcome & Manohar Sohal/Steve Herring, INL \\
\hline $8: 10-8: 40$ & INL HTE System & James O’Brien et al., INL \\
\hline $8: 40-9: 00$ & Cell Degradation - SECA Perspective & Wayne Surdoval, NETL, DOE \\
\hline 9:00 - 9:30 & SOEC Testing:Current Status & S. Elangovan et al, Ceramatec \\
\hline $9: 30-9: 50$ & Post-Mortem of Ceramatec SOEC Cells & Dave Carter et al, ANL \\
\hline $9: 50-10: 10$ & SOEC Anode Degradation (Post-Mortem) & Bilge Yildiz et al., MIT \\
\hline $10: 10-10: 20$ & Break & \\
\hline $10: 20-10: 40$ & $\begin{array}{l}\text { Solid Oxide Electrolysis Cell Performance } \\
\text { at Versa Power Systems }\end{array}$ & Eric Tang, Versa Power \\
\hline $10: 40-11: 10$ & $\begin{array}{l}\text { Performance and Degradation of Solid } \\
\text { Oxide Electrolysis Cells }\end{array}$ & Nguyen Minh, Consultant \\
\hline $11: 10-12: 30$ PM & $\begin{array}{l}\text { Discussion Session - Research needs } \\
\text { based on SOEC performance and limited } \\
\text { existing information }\end{array}$ & Ken Reifsnider \& Scott Barnett \\
\hline $12: 30-1: 30$ & Lunch & \\
\hline $1: 30-2: 00$ & Cell Degradation and Related Experience & Robert Steinberger et al., FZ Jülich \\
\hline $2: 00-2: 30$ & $\begin{array}{l}\text { Various Degradation Mechanisms in } \\
\text { SOFC }\end{array}$ & Prabhakar Singh et al., PNNL \\
\hline $2: 30-3: 00$ & $\begin{array}{l}\text { Model and Interpretation of Degradation } \\
\text { Information }\end{array}$ & Olivera Kesler, U. Toronto \\
\hline 3:00 - 3:10 & Break & \\
\hline $3: 10-4: 30$ & $\begin{array}{l}\text { Discussion Session - Research needs } \\
\text { based on existing knowledge of } \\
\text { SOEC/SOFC degradation }\end{array}$ & Prabhakar Singh \& Olivera Kesler \\
\hline $4: 30-5: 15$ & Summary of overall research priorities & Manohar Sohal \& Steve Herring \\
\hline $5: 15-5: 30$ & Future Course of Action \& Wrap-up & Manohar Sohal \\
\hline
\end{tabular}




\section{Attendee List}

\section{"Degradation in Solid Oxide Electrolysis Cells and Strategies for its Mitigation" \\ October 27, 2008 Fuel Cell Seminar \& Exposition Phoenix Convention Center, Phoenix, Arizona}

David R. Anderson

Technology Transfer \& Commercialization

Idaho National Laboratory

P. O. Box 1625

Idaho Falls, ID 83415-3805

Ph.: 208-526-9096

Cell: 208-520-0126

Fax: 208-526-0876

E-mail: david.anderson@inl.gov

Scott A. Barnett

Dept. of Materials Science \& Engineering

Northwestern University

2220 Campus Drive

Evanston, IL 60208-3108

Ph: 847-491-2447

Fax: 847-491-7820

E-mail: s-barnett@,northwestern.edu

Noriko Behling

Science \& Technology Policy Analyst

Centra Technology

6517 Deidre Terrace

McLean, VA 22101

Ph.: 703-893-1569

Fax: 703-893-1569

E-mail: behlingn@msn.com

J. David Carter

Group Leader

Ceramics Electrochemistry

Argonne National Laboratory

9700 South Cass Avenue, Bldg. 205

Argonne, IL 60439-4837

Ph.: 630-252-4544

Fax: 630-972-4544

E-mail: carter@cmt.anl.gov

Fanglin (Frank) Chen

Department of Mechanical Engineering

University of South Carolina

300 Main St.

Columbia, SC 29208

Ph.: 803-777-4875

FAX: 803-777-0106

E-mail: chenfa@,engr.sc.edu
S. (Elango) Elangovan

SOFC Product Manager

Ceramatec

2425 South 900 West

Salt Lake City, UT 84119

Ph.: 801-978-2162

Fax: 801-972-1925

E-mail: elango@ceramatec.com

Erich K Erdle

efceco (Erdle Fuel Cell \& Energy Consulting)

Auf dem Ruhbuehl 105

D-88090 Immenstaad - Germany

Ph: +49 (0) $7545 / 6103$ or 6110

Cell: +49(0) $160 / 90294398$

E-mail: erdle@,t-online.de

Ken Furusaki

General Manager

Frontier Research Laboratory

NGK Spark Plug Co. Ltd.

2808, lwasaki, Komaki, Aichi Pref. 485-8510 JAPAN

Ph.: Tel: +81(0)568-76-1275 Ext.2631

Cell: $+81(0) 9029495952$

Fax: +81(0)568-76-1295

E-mail: k-furusaki@mg.ngkntk.co.jp

Joseph H. Hartvigsen

Ceramatec

2425 South 900 West

Salt Lake City, UT 84119

Ph.: 801-978-2163

Fax: 801-972-1925

E-mail: jih@,ceramatec.com

J. Stephen Herring

Idaho National Laboratory

P. O. Box 1625

Idaho Falls, ID 83415-3860

Ph.: 208-526-9497

E-mail: j.herring@inl.gov 
Jamie Holladay

Hydrogen, Fuel Cells and Infrastructure Technologies

Program

U.S. Department of Energy, EE-2H

1000 Independence Ave., SW

Washington, DC 99352

Ph.: 202-586-8804

E-mail: Jamie.holladay@ee.doe.gov,

Jamie.holladay@pnl.gov

Yi Jiang

Associate Research/Group Leader

Saint-Gobain High Performance materials

9 Goddard Road

Northboro, MA 01532

Phone: 508-351-7841

Fax: 508-351-7701

E-mail: yi.jiang@,saint-gobain.com

Olivera Kesler

Canada Research Chair in Fuel Cell Manufacturing

Dept. of Mechanical \&

Industrial Engineering

University of Toronto

5 King's College Road

Toronto, ON M5S 3G8 CANADA

Ph.: 416-978-3835

Fax: 416-978-5573

E-mail: kesler@mie.utoronto.ca

Peiwen (Perry) Li

Aerospace and Mechanical Engineering Dept.

University of Arizona

P. O. Box 210119

Tucson, AZ 85721-0119

Ph.: 520-626-7789

Fax: 520-621-8191

E-mail: peiwen@email.arizona.edu

Nguyen Minh

Consultant

11701 Quartz Avenue

Fountain Valley, CA 92708

Cell: 714-955-1292

E-mail: Nqminh1@gmail.com
Yeshwanth Narendar

Group Leader, Solid Oxide Fuel Cells

Saint-Gobain High Performance Materials

9 Goddard Road

Northborough, MA 01532

Phone: 508-351-7594

E-mail: yeshwanth.narendar@saint-gobain.com

James E. O’Brien

Idaho National Laboratory

P. O. Box 1625

Idaho Falls, ID 83415-3870

Ph.: 208-526-9096

E-mail: james.obrien@inl.gov

Randy Petri

Director, Federal Programs \&

Product Development

Versa Power Systems, Inc.

8392 Continental Divide Rd., Suite 101

Littleton, CO 80127

Ph.: 303-226-0762

Cell: $720-217-8831$

E-mail: randy.petri@,versa-power.com

Kenneth Reifsnider

Educational Foundation Univ. Professor of Mechanical

Engng.

Director, Solid Oxide Fuel Cell Program

University of South Carolina

300 Main Street, Room 116

Columbia, SC 29208

Ph: 803-777-0084

Fax: 803-777-0106

E-mail: reifsnid@engr.sc.edu

Matthew M. Seabaugh

Director, Fuel Cell R\&D

NexTech Materials, Ltd.

Lewis Center, OH, 43035

Ph: 614-842-6606 ext. 107

Fax: 614-842-6607

E-mail:.seabaugh@nextechmaterials.com 
Prabhakar Singh* $^{*}$

Pacific Northwest National Laboratory

P. O. Box 999

Richmond, WA 99352

Ph.: 509-375-5945

E-mail: prabhakar.singh@pnl.gov

* (Now) Director

Connecticut Global Fuel Cell Center

United Technology Chair Professor

University of Connecticut

Storrs, CT 06269

Ph.: 860-486-8375

Fax: 860-486-8378

E-mail: singh@engr.uconn.edu

Stephen W. Sofie

Dept. of mechanical \& Industrial Engineering

201E Roberts Hall

Montana State University

P. O. Box 173800

Bozeman, MT 59717-3800

Ph.: 406-994-6299

Fax: 406-994-6292

E-mail: ssofie@me.montana.edu

Manohar S. Sohal

Idaho National Laboratory

P. O. Box 1625

Idaho Falls, ID 83415-3815

Ph.: 208-526-9412

E-mail: manohar.sohal@inl.gov

Robert Steinberger-Wilckens

Manager, Fuel Cells

Forschungszentrum Jülich

PBZ

52425 Jülich, GERMANY

Ph.: +49 (0) 2461615124

Fax: +49 (0) 2461616695

E-mail: r.steinberger@,fz-juelich.de

Carl M. Stoots

Idaho National Laboratory

P. O. Box 1625

Idaho Falls, ID 83415-3890

Ph.: 208-526-4527

E-mail: carl.stoots@inl.gov
Neal Sullivan

Director, Colorado Fuel Cell Center

Division of Engineering, BB309

Colorado School of Mines

Golden, CO 80401

Ph: 303-273-3656

Fax: 303-373-3602

E-mail:nsulliva@mines.edu

Wayne Surdoval

Technology Manager, Fuel Cells

National Energy Technology Laboratory

U. S. Department of Energy

626 Chochrans Mill Road

P. O. Box 10940

Pittsburgh, PA 15236-0940

Ph.: 412-386-6002

Fax: 412-386-4822

E-mail: wayne.surdoval@netl.doe.gov

Eric Tang

Manager, Research \& Development

Versa Power Systems

$485252^{\text {nd }}$ Street SE

Calgary, Alberta T2B 3R2 CANADA

Ph: 403-204-6111

Fax: 403-204-61110

E-mail: Eric.tang@,versa-power.com

Bilge Yildiz (absent)

Department of Nuclear Science \& Engineering

Massachusetts Institute of Technology

77 Massachusetts Avenue, 24-210

Cambridge, MA 02139-4307

Phone: 617-324-4009

Fax: 617-258-8863

E-mail: bilge@mit.edu 